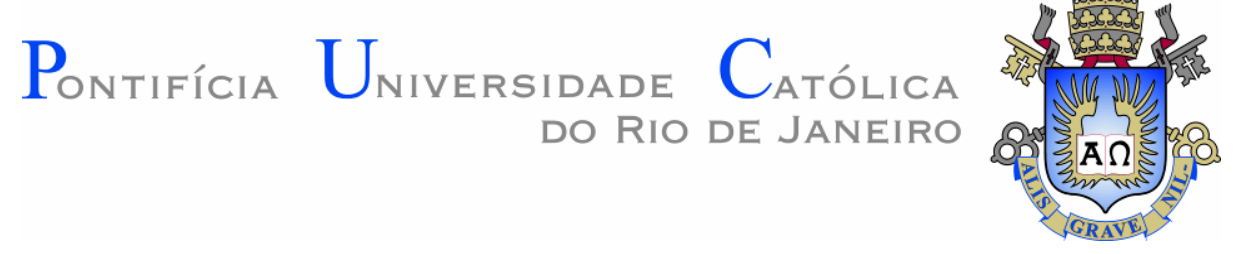

Letícia Oliveira de Souza

Mecanismos de fissuração e autocicatrização de compósitos cimentícios reforçados com tecido de curauá

Dissertação de Mestrado

Dissertação apresentada ao Programa de Pós-Graduação em Engenharia Civil da PUC-Rio como requisito parcial para obtenção do grau de Mestre em Engenharia Civil.

Orientador: Prof. Flávio de Andrade Silva Coorientadora: Drª . Lourdes Maria Silva de Souza 


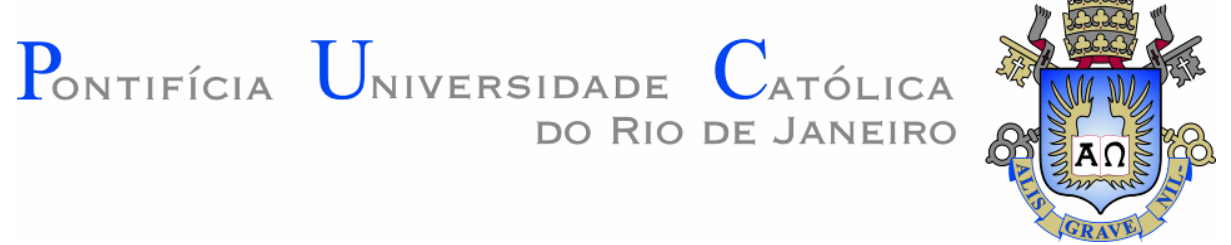

Letícia Oliveira de Souza

\section{Mecanismos de fissuração e autocicatrização de compósitos cimentícios reforçados com tecido de curauá}

Dissertação apresentada como requisito parcial para obtenção do grau de Mestre pelo Programa de Pós-Graduação em Engenharia Civil do Departamento de Engenharia Civil e Ambiental do Centro Técnico Científico da PUC-Rio. Aprovada pela Comissão Examinadora abaixo assinada.

Prof. Flávio de Andrade Silva

Orientador

Departamento de Engenharia Civil e Ambiental - PUC-Rio

Dra. Lourdes Maria Silva de Souza

Coorientadora

Departamento de Engenharia Civil e Ambiental - PUC-Rio

Prof. Daniel Carlos Taissum Cardoso

Departamento de Engenharia Civil - PUC-Rio

Prof. Jose Roberto Moraes d'Almeida

Departamento de Engenharia Química e de Materiais - PUC-Rio

Prof. Márcio da Silveira Carvalho

Coordenador Setorial do Centro Técnico Científico - PUC-Rio 
Todos os direitos reservados. É proibida a reprodução total ou parcial do trabalho sem autorização da universidade, do autor e do orientador.

\section{Letícia Oliveira de Souza}

Graduada em Engenharia Civil pela Universidade Federal Fluminense - UFF - em 2015. Principais áreas de interesse: Materiais compósitos, fibras naturais, autogenous healing.

Ficha Catalográfica

Souza, Letícia Oliveira de

Mecanismos de fissuração e autocicatrização de compósitos cimentícios reforçados com tecido de curauá/ Letícia Oliveira de Souza; Orientador: Flávio de Andrade Silva/ coorientadora: Lourdes Maria Silva de Souza - 2017.

138 f. il. color; $29,7 \mathrm{~cm}$.

Dissertação de Mestrado em Engenharia Civil Pontifícia Universidade Católica do Rio de Janeiro, Departamento de Engenharia Civil e Ambiental. 2017.

Inclui referências bibliográficas.

1. Engenharia civil - Teses. 2. Compósitos. 3. Fibras Naturais. 4.Curauá. 5. Autocicatrização. I. Silva, Flávio de Andrade. II. Souza, Lourdes Maria Silva de. III. Pontifícia Universidade Católica do Rio de Janeiro. Departamento de Engenharia Civil e Ambiental. IV. Título. 


\section{Agradecimentos}

Esses poucos anos de mestrado foram, pra mim, de muito esforço, estudo e, principalmente, aprendizado. Muitas pessoas fizeram parte do meu caminho e por conta disso sou muito grata. Gostaria de expressar aqui minha gratidão a algumas delas.

Ao professor Flávio, meu orientador, que me apresentou ao mundo da pesquisa. É para mim um grande exemplo de pesquisador, partilhando seus conhecimentos e sempre em busca do melhor trabalho possível. Agradeço por toda paciência com a minha falta de experiência e com os momentos inseguros, assim como toda a disponibilidade mostrada. À minha coorientadora, Lourdes, que sempre esteve à disposição. Por muitas vezes além da dissertação, me ajudando em tudo o que precisei, se mostrando uma pessoa muito generosa. Espero ter construído aqui mais que uma parceria com vocês.

Um trabalho experimental requer muitos recursos, principalmente humano. Gostaria de agradecer a toda equipe e, hoje, amigos do LEM-DEC: ao Euclides, por toda a experiência e ajuda nos procedimentos, ao Rogério, Marques, Zé Nilson, Bruno e Carlos, por sempre estarem dispostos e comprometidos com os diversos trabalhos desenvolvidos. Aos estagiários Carol e Lucas, por toda a ajuda no dia-a-dia do laboratório.

A PUC-Rio além de toda a infraestrutura também me proporcionou fazer lindas amizades que sem elas, não seria possível grande parte deste trabalho. Agradeço ao Felipe, que me ajudou muito no início dos procedimentos experimentais, compartilhando tanto suas habilidades de moldagem quanto copos quando era necessário. Agradeço também à Gisele, de "companheira de matérias" a " melhor pessoa da vida" em poucos meses. E, é claro, à Ana, Daiana e Rebecca, pessoas que ouvem meus desesperos diários e me confortam também diariamente, seja com palavras e ajudando como podem: molhando corpos de prova, tirando medidas, ajeitando meu excel, ajudando com títulos de e-mail e todas essas coisas 
provenientes da rotina. Aos "amigos do café": Rafael, Hélvio, César, Malko, Alan, Mari, Jéssica e Tata, pelas discussões acaloradas acerca de assuntos tanto banais quanto políticos. Um agradecimento muito especial ao Bruno, que tem muita paciência comigo em todos os momentos. Pelo apoio, aguentando todos os desesperos explicáveis e inexplicáveis. É um parceiro incrível que a vida foi extremamente generosa em me dar.

Agradeço também à minha aos meus pais, Cida e Luis, e irmão Bruno, pelo amor e compreensão das ausências necessárias, mesmo em momentos importantes. Hoje tudo valeu a pena. Aos meus padrinhos, Lygia e José, por todo incentivo e orações, por sempre acreditarem em mim.

Agradeço à empresa Solintec pela parceria. Principalmente ao técnico Jorge, muito empenhado em fazer lindas lâminas de um material tão complexo. Agradeço também ao professor Freire e ao Giancarlo pela ajuda com o DIC. E também ao CNPq, pelo suporte financeiro. 


\section{Resumo}

Oliveira de Souza; Letícia; de Andrade Silva, Flávio (orientador); Silva de Souza, Lourdes Maria (coorientadora). Mecanismos de fissuração e autocicatrização de compósitos cimentícios reforçados com tecido de curauá. Rio de Janeiro, 2017. 138p. Dissertação de Mestrado Departamento de Engenharia Civil e Ambiental, Pontifícia Universidade Católica do Rio de Janeiro.

O presente trabalho tem como objetivo o estudo do comportamento mecânico, os mecanismos de fissuração e a autocicatrização de compósitos cimentícios reforçados com fibras de curauá. Desenvolveram-se três tipos de compósitos distintos, cada um reforçado com uma, três ou cinco camadas de tecido unidirecional de curauá. O comportamento mecânico foi avaliado por meio de ensaios de tração direta e flexão a quatro pontos. Estudaram-se os mecanismos de fissuração por meio de fotografias obtidas ao longo dos ensaios, além de análises por correlação digital de imagens (Digital Image Correlation - DIC). Estágios de carregamento foram identificados e associados com o espaçamento entre as fissuras formadas. Os corpos de prova de flexão foram instrumentados com strain gauges nas faces inferior e superior, a fim de medir as deformações de tração e compressão. Dessa forma, foi possível realizar um estudo sobre o desenvolvimento da linha neutra e correlacionar as deformações com espaçamento entre fissuras. A capacidade de autocicatrização dos compósitos foi avaliada por meio de ensaios mecânicos cíclicos e de carregamento contínuo, e também por acompanhamento da evolução das fissuras. Estas foram monitoradas com o auxílio de microscópio estereoscópico. As amostras foram expostas a diferentes ambientes (seco, ciclos de água borrifada, imersão em água) e a influência deles foi avaliada. Todos os compósitos apresentaram strain/deflection hardening com formação de múltiplas microfissuras. Fissuras na presença de água apresentaram cicatrização total e parcial, demostrando que o material desenvolvido é promissor para a ocorrência de autocicatrização.

\section{Palavras-chave}

Compósitos cimentícios; autocicatrização; fibras naturais; curauá. 


\section{Abstract}

Oliveira de Souza; Letícia; de Andrade Silva, Flávio (advisor); Silva de Souza, Lourdes Maria (co-advisor). Cracking mechanisms and autogenous healing capability of cementitious composites reinforced with curaua fabric. Rio de Janeiro, 2017. 138p. Dissertação de Mestrado Departamento de Engenharia Civil e Ambiental, Pontifícia Universidade Católica do Rio de Janeiro.

The present work aims to study the mechanical behavior, cracking mechanisms and the autogenous healing capability of cementitious composites reinforced with curauá fabric. Composites with one, three and five fabric layers were produced. Their mechanical behavior was evaluated through direct tensile and four point bending tests. The cracking mechanisms were studied using image analysis of both photographs took during the tests and Digital Image Correlation (DIC). Various stages of loading were identified and associate with the crack formation. The effect of flexural cracking on the composite neutral axis position was analyzed using strain-gages and correlated with the crack spacing. The autogenous healing capability of the three layered composite system was analyzed by means of the mechanical behavior, in cyclic bending and constant load tests. The crack evolution was follow with microscope stereoscope. The samples were subject to several conditions ( $\mathrm{RH}$ of $55 \%$, cycles of spayed water, water immersion) and their influence was evaluated. All the composites presented strain/deflection hardening behavior with multiple microcrack formation. Cracks exposed to water were partially or totally healed, demonstrating that three layered composite is a promising material for autogenous healing.

\section{Keywords}

Cementitious composites; self-healing; natural fibers; curauá. 


\section{Sumário}

1 Introdução 19

1.1. Motivação 19

1.2. Objetivos 21

1.3. Organização da Dissertação 21

2 Revisão Bibliográfica 23

2.1. Fibras naturais 23

2.1.1. Estrutura morfológica e composição química. 25

2.1.2. Propriedades físicas e mecânicas. 28

2.2. Compósitos reforçados com fibras 30

2.2.1. Compósitos reforçados com fibras de curauá 34

2.2.2. Matriz cimentícia 36

2.3. Autocicatrização autônoma 38

2.3.1. Mecanismos de autocicatrização. 40

2.3.2. Estratégias para se obter autocicatrização 41

2.3.3. Autocicatrização autógena em materiais que apresentam $\begin{array}{ll}\text { comportamento strain-hardening. } & 46\end{array}$

3 Desenvolvimento e Caracterização dos Materiais 49

3.1. Introdução 49

3.2. Matriz cimentícia $\quad 49$

3.2.1. Materiais 49

3.2.2. Dosagem e Processamento 51

3.2.3. Propriedades da matriz no estado fresco 51

3.2.4. Propriedades da matriz no estado endurecido 52

3.3. Fibra de curauá $\quad 54$

3.3.1. Microestrutura 56

3.3.2. Tração 58

3.3.3. Absorção 60

$\begin{array}{ll}\text { 3.4. Conclusões } & 61\end{array}$ 
4 Comportamento mecânico e mecanismos de fissuração dos compósitos cimentícios reforçados com fibra de curauá

4.1. Introdução 63

4.2. Procedimento experimental 63

4.2.1. Fabricação dos compósitos 63

4.2.2. Ensaios 65

4.3. Resultados e Discussões 72

4.3.1. Comportamento dos compósitos submetidos à tração direta $e$ seus mecanismos de fissuração 72

4.3.2. Comportamentos dos compósitos à flexão e seus mecanismos de fissuração 85

4.4. Conclusões 90

5 Capacidade de autocicatrização do compósito reforçado por três camadas de tecido unidirecional de curauá 91

5.1. Introdução 91

5.2. Procedimento experimental 91

5.2.1. Ensaios 91

5.3. Resultados e discussões $\quad 97$

5.3.1. Influência do carregamento contínuo durante 28 dias em compósitos pré-fissurados e sua capacidade de autocicatrização

5.3.2. Influência de diversas condições de exposição durante 28 dias em compósitos pré-fissurados

5.3.3. Capacidade de autocicatrização do compósito reforçado com três camadas de tecido de curauá sob carregamento cíclico

6 Conclusões e trabalhos futuros

6.1. Conclusões 123

6.2. Sugestões para trabalhos futuros 124

7 Referências bibliográficas 


\section{Lista de Figuras}

Figura 2-1 - Classificação das fibras vegetais, adaptado de [17] ........................ 23

Figura 2-2 - Estrutura morfológica de uma fibra natural, adaptado de [26].......... 26

Figura 2-3 - Comportamento mecânico típico de compósitos que apresentam

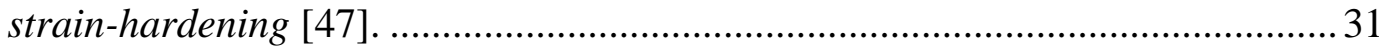

Figura 3-1 - Granulometria da areia fina utilizada. ...........................................50

Figura 3-2 - Etapas da mistura da argamassa: (a) areia com metade da água;

(b) materiais cimentícios; (c) argamassa antes de adicionar o superplastificante

e (d) após adicionar o superplastificante. ........................................................... 51

Figura 3-3 - Etapas do espalhamento: (a) argamassa sendo colocada no tronco de cone; (b) medida do primeiro diâmetro; (c) medida do segundo diâmetro e (d) detalhe da borda, na qual é possível observar que não houve segregação de materiais. 52

Figura 3-4 - Arranjo experimental do ensaio de compressão. .53

Figura 3-5 - Evolução no tempo da resistência à compressão da matriz

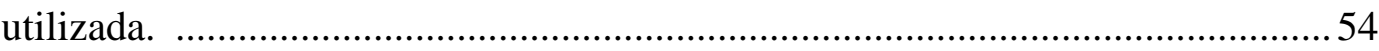

Figura 3-6 - Aparato usado para separar as fibras no processo inicial. ..................55

Figura 3-7 - Fibras de curauá antes (esquerda) e depois (direita) de passarem

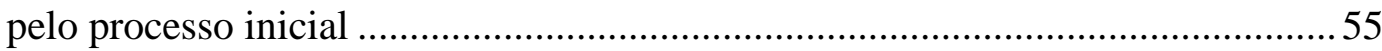

Figura 3-8 - (a) MEV utilizado e (b) detalhe das amostras de fibra de curauá. .... 56 Figura 3-9 - Contorno para cálculo da área da seção transversal da fibra de curauá.

Figura 3-10 - Micrografias da fibra de curauá: (a) superfície lateral; (b)

exemplo de seção transversal; (c) exemplo de seção transversal e

(d) identificação de parte da estrutura morfológica.

Figura 3-11 - Guia de papel cartão para ensaio de tração do filamento da fibra de curauá. O filamento é posicionado no centro da guia que é dobrada e colada com cola instantânea. Posteriormente, as laterais da guia são cortadas para não influenciarem o ensaio. 
Figura 3-12 - Arranjo experimental do ensaio de tração das fibras de curauá

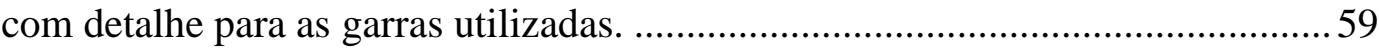

Figura 3-13 - Curva resistência versus deformação da fibra de curauá...................60

Figura 3-14 - Curva do ganho de massa do curauá ao longo do tempo. ................ 61

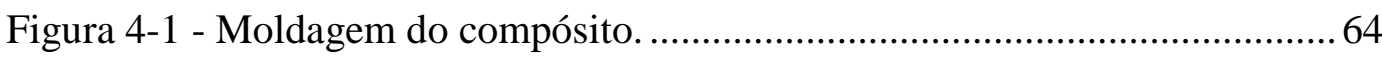

Figura 4-2 - Diferença entre as espessuras dos três compósitos............................. 64

Figura 4-3 - Arranjo experimental usado para ensaios de tração........................... 66

Figura 4-4 - Esquema de um subset de referência com a correlação do mesmo

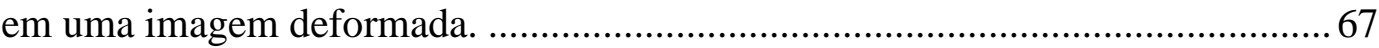

Figura 4-5 - Arranjo experimental utilizado para o DIC. ......................................6 68

Figura 4-6 - Amostra caracterizada com fundo branco fosco, com pontos preto

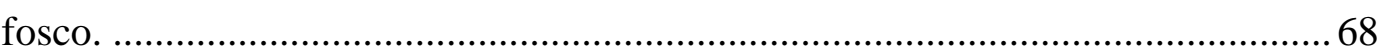

Figura 4-7 - Demarcação da área de interesse com detalhe do subset. .................69

Figura 4-8 - Posicionamento dos strain gages e suporte para os LVDTs............. 71

Figura 4-9 - Arranjo experimental usado em ensaios de flexão a quatro pontos.

Célula usada para amostras de 3 e 5 camadas.

Figura 4-10 - Zonas que representam os estágios de carregamento do compósito de três camadas submetido à tração direta. .73

Figura 4-11 - Resposta dos três diferentes de compósitos à tração direta............. 74

Figura 4-12 - (a) Reta aproximada para cálculo das rigidezes; e (b) Valores

das rigidezes por Zona, II e III, para os três tipos de compósitos.

Figura 4-13 - Compósitos submetidos à flexão e seus respectivos espaçamentos entre fissuras. .75

Figura 4-14 - Campos de deformação em diferentes momentos dos compósitos reforçados com (a) 1 camada; (b) 3 camadas; e (c) 5 camadas. .77

Figura 4-15 - Pontos referentes às imagens analisadas dos compósitos............... 78

Figura 4-16 - Detalhe de regiões que contém mais de uma fissura.......................79

Figura 4-17 - Identificação de três zonas: localização, "1" e região uniforme no campo de deformações 80

Figura 4-18 - Posição Y versus deformação para os compósitos reforçados com (a) 1 camada; (b) 3 camadas; e (c) 5 camadas de tecido de curauá. 81 Figura 4-19 - Comparação entre o padrão de fissuração gerado pelo DIC com o padrão de fissuração real após o término do ensaio dos compósitos reforçados 
com (a) uma camada; (b) três camadas; e (c) cinco camadas de tecido de curauá

Figura 4-20 - Comparação entre diferentes compósitos solicitados à tração direta.

Figura 4-21 - Resposta dos três tipos de compósitos sob flexão a quatro pontos e seus respectivos espaçamentos entre fissuras.

Figura 4-22 - Modos de ruptura dos compósitos de três (acima) e cinco (abaixo) camadas sob flexão

Figura 4-23 - Deformações (a) de compressão e (b) de tração dos compósitos reforçados com tecidos de curauá.

Figura 4-24 - Final do ensaio de flexão do compósito reforçado com uma camada.

Figura 4-25 - Desenvolvimento da linha neutra normalizada dos três compósitos

Figura 5-1 - Esquematização das condições que as amostras foram expostas durante 28 dias após a pré-físsuração. Todos os procedimentos ocorreram dentro de sala com ambiente controlado.

Figura 5-2 - Arranjo experimental usado no ensaio de carregamento constante:

(a) suporte para apoio do LVDT; (b) rolete para distribuição da carga nos mesmos pontos do carregamento de pré-fissuração; (c) início do carregamento e (d) amostras totalmente carregadas.

Figura 5-3 - Monitoramento de fissuras durante o ensaio de carga contínua com o uso de um microscópio estereoscópico portátil (a) e localização das fissuras que foram acompanhadas ao longo do ensaio (b).

Figura 5-4 - (a) Localização e orientação das amostras; e (b) lâminas delgadas.

Figura 5-5 - Comportamento do compósito com três camadas de fibra de curauá submetido ao ensaio de flexão. Níveis de deslocamento adotados no ensaio cíclico, 10 e $20 \mathrm{~mm}$, indicados .95

Figura 5-6 - Arranjo experimental para exposição das amostras submetidas ao ensaio cíclico.

Figura 5-7 - (a) Localização dos eixos onde as fissuras foram observadas, dois laterais e um central, e (b) exemplo de uma amostra após 3 ciclos com detalhe da correspondência de cores com os ciclos. 
Figura 5-8 - Cálculo da rigidez inicial. (a) Parte do gráfico analisada; e (b) procedimento de cálculo. .98

Figura 5-9- Pré-fissuração e comportamento dos compósitos após 28 dias sem e com carga contínua.

Figura 5-10 - Comportamento do deslocamento ao longo dos 28 dias das amostras submetidas ao carregamento contínuo,sem e com ciclos de água borrifada. 100

Figura 5-11 - Exemplo de como as fissuras de amostras submetidas ao carregamento contínuo se comportaram, se dividindo em outras fissuras. 101

Figura 5-12 - Média da abertura das amostras submetidas aos cilos de água borrifada (97 m) e não submetidas aos ciclos (53 m); (b) detalhe superior das amostras; e (c) detalhe inferior das amostras, mostrando a diferença das aberturas das fissuras. 102

Figura 5-13 - Deslocamento adicional recuperado após 28 dias sob carga conínua.

Figura 5-14 - Exemplo de fissura de amostra submetida ao ensaio de carga contínua após (a) 2 dias; e (b) 27 dias de carregamento.

Figura 5-15 - Pré-fissuração e comportamento dos compósitos submetidos a carregamento contínuo submetidos e não submetidos aos ciclos de água borrifada. 104

Figura 5-16 - Comparação entre as curvas dos compósitos que não foram submetidos à carga contínua. As amostras foram submetidas aos ciclos de água borrifada ou não. A curva do ensaio monotônico também é apresentada

Figura 5-17 - Seis exemplos de comportamento das fissuras de uma mesma amostra após ser exposta a 4 ciclos de água borrifada; escala $500 \mu \mathrm{m}$. 106

Figura 5-18 - Exemplos de duas fissuras após serem expostas a (a) e (c) 4 ciclos; e (b) e (d) 12 ciclos de água borrifada; detalhe de parte da fissura preenchida.

Figura 5-19 - Comparação entre amostras submetidas a ciclos de molhagem de 12 horas e imersas com amostra sem exposição a água. 108 Figura 5-20 - Exemplo de uma fissura após (a) a pré-fissuração sem nenhum ciclo de molhagem; (b) 1 ciclo de molhagem e (c) 13 ciclos de molhagem com detalhes em amarelo das partes cicatrizadas 
Figura 5-21 - Exemplo de uma fissura após (a) a pré-fissuração sem nenhum ciclo de molhagem; (b) 1 ciclo de molhagem e (c) 13 ciclos de molhagem.

Figura 5-22 - Exemplo de uma fissura após (a) a pré-fissuração sem nenhum ciclo de molhagem; (b) 1 ciclo de molhagem e (c) 13 ciclos de molhagem.

Figura 5-23 - Micrografias da lâmina delgada T1 sob luz polarizada simples

(a) Localização da fissura; (b) extensão da fissura; (c) produto partindo

das superfícies laterais; e (d) detalhe do produto.

Figura 5-24 - Micrografias da seção transversal da amostra T1, evidenciando

as fibras encolhidas depois do processo de fabricação da lâmina delgada sob (a) luz polarizada simples e; (b) luz polarizada cruzada.

Figura 5-25 - Resposta do ensaio cíclico das amostras submetidas a nível de deslocamento de (a) $10 \mathrm{~mm}$ e (b) $20 \mathrm{~mm}$.

Figura 5-26 - Evolução das propriedades mecânicas a cada ciclo do ensaio cíclico das amostras submetidas a ambiente seco com (a) $10 \mathrm{~mm}$ e

(b) $20 \mathrm{~mm}$ de nível de carregamento.

Figura 5-27- Evolução do comportamento de uma fissura de amostra submetida ao ensaio cíclico de nível de carregamento de $20 \mathrm{~mm}$ (a) após o primeiro ciclo; (b) após o segundo ciclo e (c) após o terceiro ciclo.

Figura 5-28 - Evolução do número de fissuras e espaçamento entre as mesmas de amostra submetida ao ensaio cíclico de nível de deslocamento de

(a) $10 \mathrm{~mm}$ e (b) $20 \mathrm{~mm}$.

Figura 5-29 - Resposta ao carregamento cíclico dos compósitos submetidos a nível de deslocamento de (a) $10 \mathrm{~mm}$ e (b) $20 \mathrm{~mm}$, ambos submetidos ao ciclo de água borrifada.

Figura 5-30 - Evolução das propriedades mecânicas a cada ciclo do ensaio cíclico das amostras submetidas a ciclos de água borrifada com (a) $10 \mathrm{~mm}$ e (b) $20 \mathrm{~mm}$ de nível de carregamento. 119

Figura 5-31 - Evolução do comportamento da fissura de $19 \mu \mathrm{m}$ (a) após o primeiro ciclo e após 12 ciclos de água borrifada; (b) após o segundo ciclo e 25 ciclos de água borrifada e (c) após o terceiro ciclo e após 37 ciclos de água borrifada. 120

Figura 5-32 - Evolução do comportamento da fissura de $25 \mu \mathrm{m}$ (a) após o primeiro ciclo e após 12 ciclos de água borrifada; (b) após o segundo 
ciclo e 25 ciclos de água borrifada e (c) após o terceiro ciclo e após 37 ciclos de água borrifada.

Figura 5-33 - Evolução do comportamento da fissura de $44 \mu \mathrm{m}$ (a) após o primeiro ciclo e após 12 ciclos de água borrifada; (b) após o segundo ciclo e 25 ciclos de água borrifada; (c) após o terceiro ciclo e após 37 ciclos de água borrifada; (d) continuação da mesma fissura após o segundo ciclo e 25 ciclos de água borrifada e (e) continuação da mesma fissura logo antes do terceiro ciclo e após 37 ciclos de água borrifada.

Figura 0-1 - Micrografia da lâmina delgada S1. (a) Propagação da fissura por entre a zona interfacial dos agregados; fibra transversal sob (b) luz polarizada normal e; (c) luz polarizada cruzada.

Figura 0-2 - Fissura mostrada no Capítulo 5 sob luz polarizada cruzada (b), (c) e (d).

Figura 0-3 - Micrografias ressaltando a microestrutura transversal da fibra de curauá 


\section{Lista de Tabelas}

Tabela 2-1 - Composição química de diferentes fibras naturais, adaptada de [30]. 27

Tabela 2-2 - Composição química da fibra de curauá..........................................2 27

Tabela 2-3 - Propriedades mecânicas de fibras naturais, adaptada de [30]........... 29

Tabela 2-4 - Propriedades mecânicas da fibra de curauá. ...................................... 30

Tabela 2-5 - Símbolos usados na química do cimento. .......................................... 37

Tabela 3-1 - Composição química e massa específica do metacaulim...................50

Tabela 3-2 - Área da seção transversal da fibra de curauá....................................57

Tabela 3-3 - Propriedades mecânicas da fibra de curauá. ...................................... 60

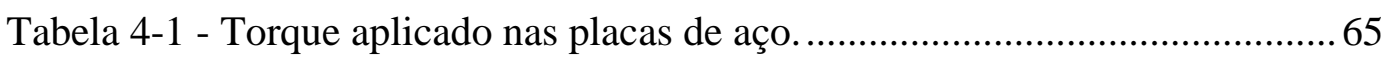

Tabela 4-2 - Resumo dos valores das propriedades mecânicas para os três

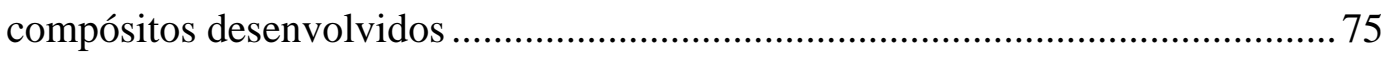

Tabela 4-3 - Quantidade de fissuras, tamanho médio e espaçamento entre elas após o término do ensaio de tração

Tabela 4-4 - Abertura média das fissuras dos três tipos de compósitos ao nível de 4,8 MPa por visualização das curvas de deformação geradas pelo DIC.

Tabela 4-5 - Abertura média das fissuras formadas no centro dos compósitos após o ensaio de flexão. 86

Tabela 4-6 - Propriedades mecânicas dos três compósitos quando submetidos ao ensaio de flexão. 86

Tabela 5-1 - Valor das cargas adicionadas em cada amostra para o ensaio de carga contínua.

Tabela 5-2 - Número, média e abertura máxima das fissuras após a préfissuração, por linha

Tabela 5-3 - Resumo das propriedades mecânicas avaliadas a cada ciclo do ensaio cíclico das amostras submetidas a $10 \mathrm{~mm}$ e $20 \mathrm{~mm}$ de deslocamento, sem presença de água.

Tabela 5-4 - Média das fissuras por ciclo de amostras submetidas aos ensaios cíclicos de nível de carregamento de $10 \mathrm{~mm}$ e $20 \mathrm{~mm}$, por linha. 
Tabela 5-5 - Evolução da média das aberturas das fissuras formadas no primeiro ciclo dos ensaios cíclicos de nível de carregamento de $10 \mathrm{~mm}$ e $20 \mathrm{~mm}$, por linha.

Tabela 5-6 - Resumo das propriedades mecânicas avaliadas a cada ciclo do ensaio cíclico das amostras submetidas a $10 \mathrm{~mm}$ e $20 \mathrm{~mm}$ de deslocamento, com ciclos de água borrifada. 
Don't panic!

Douglas Adams, The hitchhiker's guide to the galaxy 


\section{Introdução}

\subsection{Motivação}

Com o passar dos anos, uma grande variedade de materiais usados na engenharia, incluindo cerâmicas, plásticos, cimento e produtos derivados do gesso, passaram a incorporar fibras com o objetivo de melhorar suas propriedades. Essas propriedades compreendem: resistência à tração, módulo de elasticidade, controle de fissuração, tenacidade, fadiga, resistência ao impacto e abrasão, retração, expansão, características térmicas e resistência ao fogo. Há vários tipos de fibras disponíveis no mercado. Em geral elas são divididas em fibras de aço, de vidro, sintéticas e fibras naturais [1]. A forma com que são usadas também varia, podendo ser dispostas como em polpa, curtas ou tecidos.

O interesse pelo uso de materiais sustentáveis é crescente à medida que o contexto mundial se volta para as mudanças climáticas. O uso de materiais que necessitam de menos quantidade de energia e emitem menos gases tóxicos em sua produção, se torna cada vez mais atraente. A construção civil é responsável por grande parte da emissão de gases tóxicos, principalmente o $\mathrm{CO}_{2}$, tanto pelo uso de cimento quanto do aço. Visando alternativas para diminuir o consumo de cimento, uma prática adotada é a substituição de parte dele por adições de materiais que agem como materiais cimentícios [2]. Exemplos dessas adições são a escória de alto forno e as pozolanas, tais como cinza volante, sílica ativa, metacaulim e cinzas de cana de açúcar [3]. Ainda, com uma combinação de boas propriedades mecânicas e físicas e benefícios ambientais, o uso de fibras naturais provenientes de fontes renováveis utilizadas como reforço em materiais compósitos é uma alternativa viável para elementos não estruturais [4].

Há muito tempo, materiais frágeis, como cerâmica feita de tijolos de argila cozidos no sol, são reforçados com fibras. Apesar disso, só a partir de 1970, o conceito de materiais cimentícios reforçados com fibras naturais foi melhor desenvolvido com o objetivo de substituir fibras manufaturadas e de amianto [5]. De acordo com Swamy, o uso de compósitos reforçados com fibras naturais como 
painéis finos para fachadas, elementos de cobertura e componentes pré-fabricados pode representar uma contribuição significativa para a infraestrutura de países em desenvolvimento. As fibras naturais estão disponíveis em vários países, possuem baixo custo e baixa densidade, contribuindo para elementos mais leves, além de serem biodegradáveis, provenientes de fontes renováveis, não são perigosas para saúde na sua produção e não são abrasivas, contribuindo para a questão ambiental [6]. A principal vantagem dos reforços de fibra natural é o comportamento que o compósito adquire após ocorrer as primeiras fissuras: as fibras formam pontes entre as fissuras que ocorrem na matriz e transferem as forças entre elas. A tenacidade existente na pós-fissuração pode permitir o uso mais intensivo desse tipo de compósito na construção civil [4]. Fibras naturais também apresentam um comportamento adequado para reduzir fissuras por retração plástica [7] e boas propriedades de isolamento térmico [8].

Apesar das vantagens, há dificuldades em se produzir compósitos em grande escala pela falta de conhecimento em como aumentar a durabilidade sem deixar que os materiais percam suas características dúcteis [9]. Esse problema de durabilidade é associado com a degradação das fibras em ambiente alcalino. Isso faz com que o material sofra uma redução na tenacidade e na resistência quando ocorrem as primeiras fissuras [10]. Além disso, as fibras naturais possuem variações significativas na composição química, que é influenciada pelas condições geográficas, climáticas e variações no cultivo, como a qualidade do solo, nível de maturação e o processo de maceração, mesmo com fibras de uma mesma espécie. Suas propriedades físicas, como diâmetro, comprimento e rugosidade também variam. Todos esses fatores fazem com que haja dispersão nas propriedades mecânicas das fibras, levando a um alto coeficiente de variação [11]. Mesmo assim, com um traço da matriz adequado para evitar a mineralização e levando em consideração as propriedades mecânicas das fibras e seus altos coeficientes de variação, é possível desenvolver materiais apropriados para fins construtivos [12].

O concreto, um material frágil, geralmente é reforçado para suportar esforços de tração, seja ela direta ou na flexão. Ainda assim, as fissuras são inevitáveis e a presença delas gera necessidade de inspeção, manutenção e, com isso, custos. Assim, o maior controle das fissuras é de grande interesse e a chamada autocicatrização das fissuras poderia auxiliar nesse controle. Alguns 
autores definem que a autocicatrização só acontece quando, além do bloqueio físico das fissuras, há a recuperação das propriedades mecânicas e físicas [13]. O concreto por si só possui propriedades intrínsecas que levam a esse fenômeno por conta da sua composição química, que possibilita a precipitação de cristais de carbonato de cálcio e de produtos de hidratação. As fibras naturais possuem uma microestrutura capaz de criar uma rede porosa, podendo conduzir umidade por toda a matriz. Assim, a umidade disponível seria capaz de ativar a hidratação tardia, que junto com as reações de carbonatação, conduziria à cicatrização das fissuras [14].

Assim, esta pesquisa se propõe em desenvolver materiais compósitos cuja matriz é de composição tal que minimize possíveis problemas de durabilidade e que apresente um comportamento de múltiplas microfissuras pouco espaçadas, facilitando sua autocicatrização.

\subsection{Objetivos}

Os objetivos dessa pesquisa incluem:

- Avaliar e comparar as respostas mecânicas de três tipos de compósitos reforçados com tecido de curauá submetidos a ensaios de tração direta e flexão a quatro pontos.

- Fazer um estudo acerca dos mecanismos de fissuração dos compósitos desenvolvidos a partir de análises de fotos tiradas ao longo dos ensaios e por campos de deformação gerados por DIC.

- Avaliar a capacidade de autocicatrização do compósito reforçado com três camadas de tecido quando exposto a diferentes ambientes e solicitações. Essas solicitações buscam simular o material submetido a carregamentos repetidos (ensaio cíclico) e a carregamento permanente (carga contínua). Tanto o comportamento mecânico quanto o aspecto das fissuras desenvolvidas são avaliados.

\subsection{Organização da Dissertação}

O Capítulo 1 traz a introdução e os objetivos da pesquisa.

O Capítulo 2 traz a revisão bibliográfica, contendo informações gerais das fibras naturais, com ênfase no curauá. Além disso, cita trabalhos de compósitos 
cimentícios com tecidos de fibras naturais, descrevendo seu comportamento mecânico.

O Capítulo 3 apresenta a caracterização da matriz utilizada em estado fresco e endurecido, bem como a caracterização da fibra em termos de resistência a tração e sua microestrutura.

O Capítulo 4 descreve o desenvolvimento, a caracterização mecânica e os mecanismos de fissuração de compósitos cimentícios reforçados com tecido unidirecional de curauá.

O Capítulo 5 aborda o estudo acerca da capacidade de autocicatrização de um dos compósitos desenvolvidos, abrangendo aspectos do comportamento mecânico e da evolução das fissuras.

O Capítulo 6 traz as conclusões do presente trabalho e sugestões para continuação e complementação do mesmo. 


\section{Revisão Bibliográfica}

\subsection{Fibras naturais}

As fibras naturais podem ser classificadas em vegetais, animais e minerais, dependendo da sua origem $[15,16]$. As fibras vegetais são então classificadas como as provenientes da madeira, que podem ser flexíveis ou rígidas, e as não provenientes da madeira. Nesta última classificação tem-se quatro principais fontes de fibras vegetais mais utilizadas em compósitos cimentícios: o caule, as folhas, as frutas e sementes. Na Figura 2-1 são apresentados alguns exemplos de fibras provenientes dessas quatro fontes. Além de diretamente retiradas de suas respectivas fontes, as fibras vegetais podem vir de resíduos da indústria agrícola e subprodutos industriais como bagaço da cana de açúcar, palha de café e cascas de arroz [17].

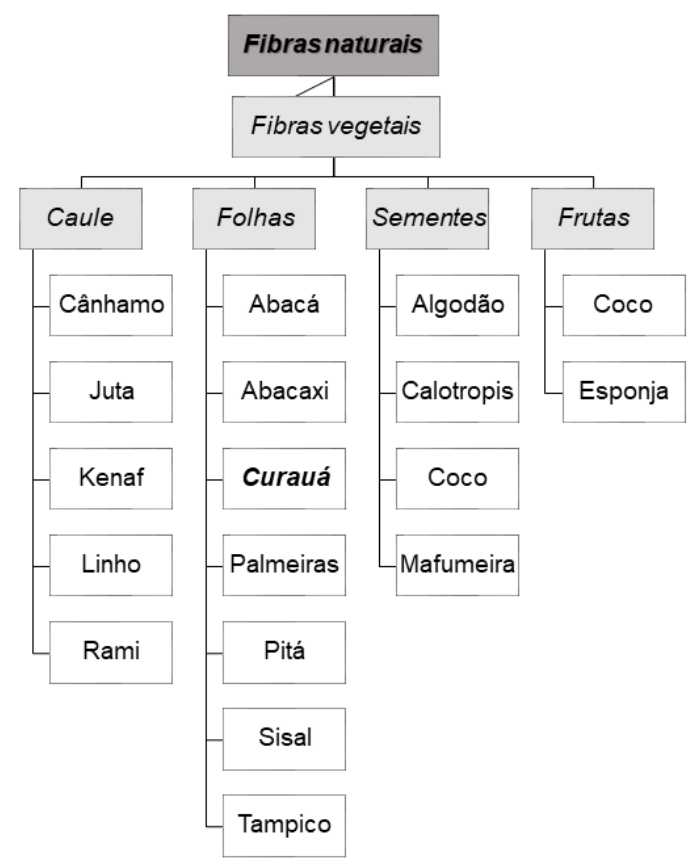

Figura 2-1 - Classificação das fibras vegetais, adaptado de [18].

As diversas vantagens de se usar fibras naturais incluem: disponibilidade em vários países, baixo custo de produção e processamento e baixa densidade, contribuindo para elementos mais leves. São também biodegradáveis, 
provenientes de fontes renováveis, não são perigosas para saúde na sua produção e não são abrasivas [6]. Essas características, junto com a questão ambiental crescente e com as boas propriedades mecânicas que as fibras naturais apresentam, fazem com que elas sejam uma boa alternativa para reforço de materiais cimentícios [19].

A fibra estudada neste trabalho é chamada de curauá (Figura 2-2), proveniente da folha da planta Ananas erectifolius, cultivada na região amazônica do Brasil. A planta é da mesma família do abacaxi e pode ser encontrada em países vizinhos, como a Guiana, Colômbia, Venezuela e Suriname, com diferentes nomes: kurowa, caroa e abacaxi selvagem [20]. A fibra é utilizada pela população local para fazer corda para arcos, redes de peixe e de dormir e como moeda de troca entre tribos.

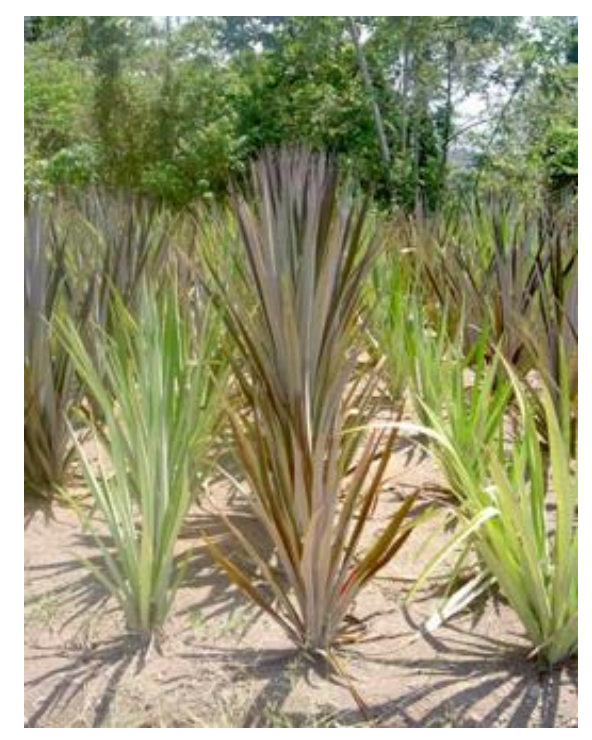

Figura 2-2 - Planta Ananas erectifolius (curauá) [21].

A primeira plantação comercial de curauá foi estabelecida na região do Pará, que é até hoje o produtor principal [22]. A planta do curauá tem folhas duras e planas, seu comprimento fica entre 100 a 150 centímetros, largura de aproximadamente $4 \mathrm{~cm}$ e espessura por volta de 0,5 cm [23]. Em geral, cada planta produz cerca de 50 folhas por ano e cada folha pesa, em média, 150 gramas. São conhecidas quatro variedades: branca, roxa, vermelha e branca clara, sendo a roxa e a branca as mais comuns [20].

Devido aos valores de resistência alcançados na tração, a fibra de curauá tem se mostrado promissora para reforçar diversos tipos de matrizes. Sua estrutura é mais fina do que a das fibras de sisal e de coco e bem mais barata que fibras 
sintéticas, apesar de apresentar propriedades mecânicas compatíveis com as de fibras de vidro, dependendo do uso [22]. Além disso, elas não exalam odores e se tornaram alvo de estudo da indústria automobilística para serem aplicadas em interiores de carros [22,24].

Para entender o comportamento das fibras, é necessário ter conhecimento acerca da sua estrutura morfológica e composição química, apresentados na seção a aseguir.

\subsubsection{Estrutura morfológica e composição química.}

Apesar das fibras naturais terem origens diversas e serem afetadas pelas características da região onde foram cultivadas, a estrutura morfológica e composição química são bastante similares entre si [25].

A alta resistência à tração que as fibras naturais provenientes de plantas geralmente possuem é devido à sua estrutura hierárquica. Cada fibra individual é formada por diversas fibrilas. Por sua vez, cada fibrila é dividida em três partes principais: a parede primária, a secundária - a mais espessa formada por três camadas - e o lúmen. As fibrilas estão ligadas entre si por meio da lamela média, formada por hemicelulose e lignina [26].

A estrutura típica de uma fibrila proveniente de fibra natural é ilustrada na Figura 2-3, na qual se pode observar uma estrutura complexa de camadas. Cada parede é formada por microfibrilas de celulose, que possuem diâmetros nanométricos e comprimentos de escala de micrometros, inseridas em uma matriz de lignina [26]. A primeira parede é a primeira camada depositada durante o crescimento celular. As microfibrilas da parede primária são dispostas de maneira aleatória, arranjo que não confere muita resistência a essa camada. Ela é fina e envolve a parede secundária, que, por sua vez, é composta por três camadas ( $\mathrm{S}$ 1, S2 e S3). A do meio é composta por microfibrilas dispostas de maneira helicoidal, arranjo que lhe confere bastante resistência. Por conta disso, as propriedades mecânicas da fibra são determinadas em grande parte pela segunda camada da parede secundária, geralmente a mais espessa. Há uma cavidade central, transversalmente disposta, o lúmen, fazendo com que as fibras naturais sejam ocas [27]. 


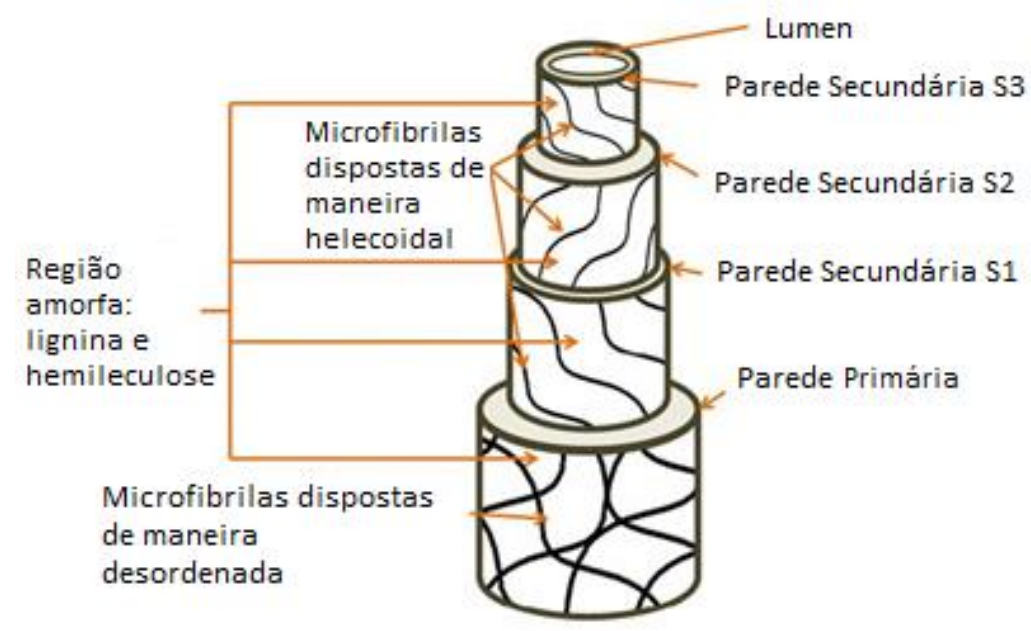

Figura 2-3 - Estrutura morfológica de uma fibra natural, adaptado de [27].

Cada parede é composta principalmente por celulose, hemicelulose e lignina. Cera e pectina também fazem parte da composição química da fibra, porém em participação menor [25].

A celulose é o componente orgânico mais rígido e resistente e, portanto, o mais importante estruturalmente, que proporciona estabilidade e resistência à fibra. Ela é um polímero natural e em suas moléculas estão incluídas unidades de glucose ligadas entre si, formando longas cadeias que alinhadas umas às outras em forma de hastes delgadas, as microfibrilas. Porém, a celulose é um polissacarídeo semicristalino com uma grande quantidade de grupos de hidroxilas, que a torna um componente hidrofílico [28]. Essa característica faz com que a fibra absorva água, perdendo tanto resistência quanto aderência quando úmida.

Hemiceluloses são polissacarídeos, assim como a celulose, só que de baixo peso molecular e ligados em cadeias mais curtas, ramificadas. A hemicelulose ajuda a incorporar a celulose, funcionando como parte da matriz, sendo fortemente ligada às microfibrilas por meio de ligações de hidrogênio. A sua estrutura é aberta e totalmente amorfa, possuindo grupos de hidroxila e acetila, o que faz a hemicelulose ser solúvel em água e higroscópica [29].

A lignina, assim como a celulose, é um polímero, mas difere desta por ser predominantemente um composto aromático, de alta complexidade. É altamente irregular em sua constituição, ou seja, amorfa. A lignina é o composto que confere rigidez à planta, funcionando como um adesivo químico dentro e entre as fibras [11]. Como composto que menos absorve água, a lignina ajuda no transporte de água na fibra. 
Pectina é um nome coletivo para heteropolissacarídeo e tem a função de dar flexibilidade à planta. Ceras consistem em tipos diferentes de álcoois e, juntamente com alguns óleos, se agrupam na superfície da fibra para oferecer proteção à mesma [27,30].

A composição química das fibras naturais possui grande influência sobre suas propriedades mecânicas. Isso porque a celulose, hemicelulose e lignina são as principais responsáveis pelos comportamentos de aderência e degradação das fibras [25]. A composição varia entre os tipos de fibra e alguns exemplos são encontrados na Tabela 2-1, em porcentagem.

Tabela 2-1 - Composição química de diferentes fibras naturais, adaptada de [31].

\begin{tabular}{|c|c|c|c|c|c|}
\hline Fibra & Celulose & Hemicelulose & Lignina & Pectina & Ceras \\
\hline Abacá & $56-63$ & $20-25$ & 7-13 & 1 & 3 \\
\hline Bambu & $26-65$ & 30 & $5-31$ & - & - \\
\hline Cânhamo & $68-74$ & $15-22$ & $3,7-10$ & 0,9 & 0,8 \\
\hline Coco & $32-44$ & $0,15-20$ & $40-45$ & $3-4$ & - \\
\hline Juta & $59-71,5$ & $13,6-20,4$ & $11,8-13$ & $0,2-0,4$ & 0,5 \\
\hline Kenaf & $31-72$ & $20,3-21,5$ & 8-19 & $3-5$ & - \\
\hline Linho & $62-72$ & $18,6-20,6$ & $2-5$ & $2-3$ & $1,5-1,7$ \\
\hline Piaçava & 28,6 & 25,8 & 45 & - & - \\
\hline Sisal & $60-78$ & $10-14,2$ & $8-14$ & 10 & 2 \\
\hline
\end{tabular}

A variabilidade da composição química se dá por conta principalmente da espécie estudada, região onde foi cultivada e métodos de extração e preparo das amostras [6,31]. A Tabela 2-2 mostra um resumo da composição química da fibra de curauá encontrada na literatura.

Tabela 2-2 - Composição química da fibra de curauá.

\begin{tabular}{c|c|c|c|c}
\hline Celulose & Hemicelulose & Lignina & Cinzas & Referência \\
$71,3 \pm 0,89$ & $17,3 \pm 2,7^{\mathrm{a}}$ & $9,53 \pm 1,01$ & $1,86 \pm 0,12$ & {$[32]$} \\
70,7 & - & 11,1 & 0,79 & {$[33]$} \\
70,4 & $16,3^{\mathrm{b}}$ & 11,1 & 2,2 & {$[34]$} \\
\hline
\end{tabular}

${ }^{\mathrm{a}}$ Extrativos

b $5,5 \%$ correspondente a extrativos

As boas propriedades mecânicas que a fibra de curauá possui são relacionadas ao seu alto teor de celulose, componente químico responsável principal pela rigidez da fibra [20]. Nas Tabelas 2-1 e 2-2, é possível perceber que 
a porcentagem desse elemento é similar ao do sisal, linho e cânhamo. Tais fibras são consideradas de alto desempenho mecânico. Essa característica acompanhada dos pequenos diâmetros da fibra de curauá, entre 7 e $10 \mu \mathrm{m}$ [18], fazem dela uma boa opção de reforço para diversos compósitos [33].

\subsubsection{Propriedades físicas e mecânicas.}

Diferente das fibras sintéticas, as fibras naturais possuem uma grande variabilidade das propriedades mecânicas por conta das diferentes condições, citadas por Yan et al. [29], dentre elas:

i. Cultivo da planta: espécie, origem geográfica, localização da fibra na planta, clima local (chuva e temperatura);

ii. Maturação: processos de crescimento que influencia diversos fatores, como espessura das paredes, aspereza, adesão entre as fibras, tamanho e forma do lúmen, porosidade e ângulo microfibrilar;

iii. Processo de extração: método de maceração (imersão em água) e separação (desfibramento);

iv. Fornecimento: transporte e estoque;

v. Condições de ensaio: taxa de velocidade, comprimento avaliado, umidade da fibra estocada e durante o ensaio, temperatura e seção transversal em diferentes pontos avaliados.

As características físicas das fibras naturais, como a estrutura e suas falhas, o ângulo microfibrilar (ângulo entre o eixo da fibra e as microfibrilas) e as dimensões, dependem basicamente dos formatos, dos tamanhos, orientações e espessuras das paredes da estrutura interna [28].

A cavidade interna das fibras, o lúmen, possui formato variável (circular, poligonal ou elíptico) e diminui a densidade das mesmas, agindo como um intensificador da capacidade de isolamento acústico e térmico [35]. Poros (vazios) também fazem parte da estrutura das fibras, indicando a existência de um grau de porosidade que não depende somente do lúmen. Quanto maior o grau de porosidade, maior será a absorção de umidade pela fibra. $\mathrm{O}$ teor de umidade das fibras influencia na resistência à tração, no grau de cristalinidade (organização das cadeias poliméricas) e dilatação, além de facilitar a sua degradação, principalmente em ambientes alcalinos [36]. 
Geralmente a resistência à tração da fibra natural diminui se seu comprimento aumentar [37,38] e isso pode se dar por dois motivos principais. $\mathrm{O}$ primeiro deles é que, quanto mais longa a fibra, maior também a probabilidade de haver defeitos, ligações mais fracas e imperfeições na estrutura da mesma, causando, ou uma ruptura mais rápida ou uma diminuição na resistência, em comparação com fibras mais curtas [6]. Além disso, o mecanismo de falha pode ser diferente entre comprimentos. A interface entre a pectina e as fibrilas é relativamente fraca, se tornando um possível local de falha, que ocorre de maneira brusca e instantânea, em fibras de comprimento maior. Se o comprimento da fibra for menor do que as fibrilas, a falha não acontece mais na interface, e sim através das células de celulose, que são bem mais resistentes do que as de pectina [38].

O diâmetro das fibras também influencia as propriedades mecânicas. A dimensão do diâmetro depende, dentre tantos fatores, do tamanho do lúmen e varia com a localização da fibra estudada. Apesar da grande dispersão dos resultados, em média, o módulo de Young decresce com o aumento do diâmetro da fibra [39]. Além disso, quanto menor o ângulo microfibrilar, ou seja, quanto mais alinhada a fibra for, maior a resistência e rigidez da mesma, enquanto ângulos maiores proporcionam maior ductilidade [25].

As propriedades mecânicas das fibras naturais variam muito dependendo da espécie. A Tabela 2-3 mostra alguns exemplos.

Tabela 2-3 - Propriedades mecânicas de fibras naturais, adaptada de [31].

\begin{tabular}{c|c|c|c}
\hline Fibra & $\begin{array}{c}\text { Resistência } \\
\text { à Tração } \\
(\mathrm{MPa})\end{array}$ & $\begin{array}{c}\text { Módulo de } \\
\text { Elasticidade } \\
(\mathrm{GPa})\end{array}$ & $\begin{array}{c}\text { Alongamento } \\
\text { máximo (\%) }\end{array}$ \\
Abacá & $400-980$ & $6,2-20$ & $1-10$ \\
Bambu & $140-800$ & $11-32$ & $2,5-3,7$ \\
Cânhamo & $270-900$ & $23,5-90$ & $1-3,5$ \\
Coco & $95-230$ & $2,8-6$ & $15-51,4$ \\
Juta & $320-800$ & 30 & $1-1,8$ \\
Kenaf & $223-930$ & $14,5-53$ & $1,5-2,7$ \\
Linho & $343-2000$ & $27,6-103$ & $1,2-3,3$ \\
Piaçava & $134-143$ & $1,07-4,59$ & $7,8-21,9$ \\
Sisal & $363-700$ & $9-38$ & $2-7$ \\
\hline
\end{tabular}

Analisando os resultados na literatura, resumidos na Tabela 2-3, para um mesmo tipo de fibra, percebemos uma grande dispersão entre os valores. Isso se dá por conta de diversos fatores além daqueles mencionados neste item. Tomczak 
et al. [23] encontraram variações nas propriedades mecânicas do curauá quando variaram o diâmetro, o tamanho da amostra e a taxa de carregamento. $\mathrm{O}$ aumento do diâmetro de 26 para $64 \mu \mathrm{m}$ resultou em um decréscimo da tensão máxima de 310 para $87 \mathrm{MPa}$ e do Módulo de Elasticidade de 96 para 34 GPa mas sem alterações do alongamento máximo. Quando o comprimento aumentou de 5 para $25 \mathrm{~mm}$, tanto a tensão máxima quanto o alongamento máximo decresceram de 223 para 173 MPa e 10,2 para 3,74 \% mas não afetou o Módulo de Elasticidade. Já a mudança na taxa de carregamento de 5 para $50 \mathrm{~mm} / \mathrm{min}$ afetou somente a resistência à tração, com aumento de 178 para $217 \mathrm{MPa}$. Alguns valores das principais propriedades mecânicas da fibra de curauá encontram-se na Tabela 2-4.

Tabela 2-4 - Propriedades mecânicas da fibra de curauá.

\begin{tabular}{c|c|c|c}
\hline $\begin{array}{c}\text { Tensão } \\
(M P a)\end{array}$ & $\begin{array}{c}\text { Módulo de } \\
\text { Elasticidade } \\
(G P a)\end{array}$ & $\begin{array}{c}\text { Alongamento } \\
\text { máximo }(\%)\end{array}$ & Referência \\
$600 \pm 200$ & $25 \pm 5$ & $5 \pm 1$ & {$[40]$} \\
$515 \pm 202$ & $22 \pm 7$ & - & {$[32]$} \\
250 & 60 & 4,5 & {$[23]$} \\
795 & 10,7 & 3,9 & {$[34]$} \\
$543 \pm 260$ & $64 \pm 33$ & $1 \pm 0,2$ & {$[41]$} \\
493 & - & - & {$[42]$} \\
$268 \pm 58$ & $11 \pm 1,6$ & $2,1 \pm 0,4$ & {$[43]$} \\
\hline
\end{tabular}

\subsection{Compósitos reforçados com fibras}

Compósito pode ser definido como uma mistura física de dois ou mais componentes, gerando um material multifásico com propriedades superiores à de seus constituintes em separado. As duas principais fases do compósito são a matriz e o reforço. A matriz age como um elemento de transferência e homogeneização dos esforços suportados, fornecendo proteção ao elemento de reforço, mantendo o confinamento do mesmo [44,45]. Já o reforço é o principal responsável por resistir às tensões de tração e pode se apresentar na forma discreta, contínua ou uma combinação dos dois [46].

A principal vantagem de usar fibras como reforços em materiais cimentícios é o comportamento que o compósito adquire após a formação das primeiras fissuras: as fibras formam pontes entre as fissuras que ocorrem na matriz e transfere as forças entre elas [45]. A tenacidade existente na pós-fissuração aumenta, melhorando as características mecânicas, principalmente a ductilidade. 
Esse comportamento adquirido com a inserção das fibras depende de vários fatores como a fração volumétrica e orientação das fibras, bem como sua geometria e comprimento que influenciam na aderência [2,45].

Quando a fração volumétrica das fibras é menor do que 1\%, as fibras tem o papel de reduzir a fissuração por retração, principalmente. Com essa fração volumétrica, elas geralmente são utilizadas em lajes e pavimentos na forma discreta. Esses elementos possuem grande superfície exposta levando a esse tipo de fissura. Quando dispersas aleatoriamente, as fibras atuam na distribuição de forças, tornando a mesma mais eficiente, além de serem menos suscetíveis à corrosão. Aumentando a fração volumétrica para até $2 \%$, as fibras já passam a ter maior influência mecânica, podendo aumentar o módulo de ruptura, tenacidade e resistência ao impacto. Quando o percentual volumétrico passa de $2 \%$ de reforço, o compósito passa a ter, possivelmente, comportamento strain-hardening [45]. Strain-hardening é um modo de ruptura não brusco e, segundo Li et al. [47], existe quando uma matriz frágil é adequadamente reforçada com fibras contínuas ou discretas. Esse comportamento é caracterizado por uma conservação ou aumento da capacidade de carga após a primeira fissura. Isto implica em um ramo ascendente da curva de tensão-deformação após a primeira fissura, geralmente seguida por um estado de formação de fissuras, como na Figura 2-4.

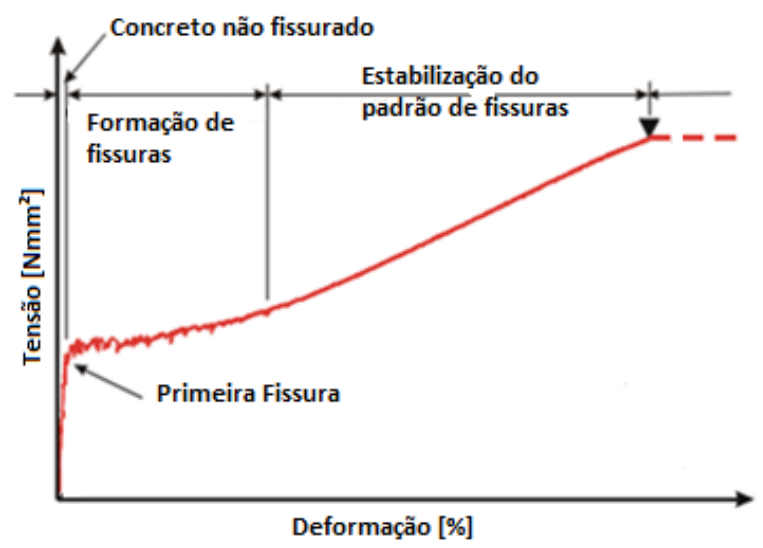

Figura 2-4 - Comportamento mecânico típico de compósitos que apresentam strain-hardening [48].

Além do strain-hardening, compósitos reforçados com fibras podem apresentar comportamento do tipo strain-softening, ou seja, o comportamento pós-fissuração é caracterizado pela queda da resistência mecânica, ou amolecimento até a ruptura do compósito [45,48]. Em geral, esse comportamento 
é mais comum quando utilizadas fibras curtas (menores que $50 \mathrm{~mm}$ ) para reforço, por não possuírem comprimento embebido suficiente para transmitir forças maiores do que as que provocam a ruptura da matriz [9].

O mecanismo de fissuração desenvolvido em um compósito reforçado com fibras é guiado pela interação entre a matriz, fibras e características da interface. Se a resistência ao arrancamento das fibras for maior do que a resistência da matriz, o compósito irá suportar cargas crescentes após a primeira fissura. As fibras agem nos compósitos no nível micro, formando "pontes" entre as microfissuras antes que elas atinjam uma abertura crítica. Assim, as fibras contribuem para a tenacidade do compósito por meios dissipativos. A partir da primeira fissura, assumimos que a matriz não contribui significativamente para a resistência do compósito, mas sim para servir de meio de transferência de tensões. Com o incremento de carga, as fibras vão tentar transferir a tensão adicional para a matriz através da interface. Se essas tensões na interface não excederem a resistência de aderência, a matriz poderá desenvolver novas fissuras. Esse processo de múltipla fissuração irá continuar até que o espaçamento entre as fissuras se tornar saturado. A partir disso, a abertura aumenta até ruptura das fibras ou até que haja concentrações de tensões que resultem no descolamento da fibra e/ou no arrancamento das mesmas [2,19].

Há vários tipos de fibra disponíveis no mercado. As categorias base são fibras de aço, de vidro, sintéticas e fibras naturais [1]. As fibras naturais, alvo deste trabalho, podem se apresentar na forma discreta, contínuas (tecidos uni e bidirecionais) [9,41], como polpa [49] e, mais recentemente, na nano escala [50]. Apesar das vantagens mencionadas no item 2.1, não são muitos os trabalhos que exploram o uso de fibras naturais contínuas como reforço de matrizes cimentícias. Alguns exemplos são citados a seguir.

Silva et al. [9] analisaram as propriedades mecânicas bem como mecanismos de fissuração de compósitos reforçados com fibras contínuas e alinhadas de sisal. Testes de tração direta e flexão a quatro pontos foram realizados nos compósitos desenvolvidos. Os compósitos foram reforçados com 5 camadas de tecido unidirecional de sisal, resultando em $10 \%$ em volume de fração de fibras. O comportamento de múltipla fissuração foi observado em ambos os testes. O módulo de elasticidade médio foi de 30 e 34 GPa para os testes de flexão e tração, respectivamente. Já a resistência máxima foi de 12 e $25 \mathrm{MPa}$ e 
tenacidade aproximada de 45 e $22 \mathrm{~kJ} / \mathrm{m}^{2}$ nos testes de tração e flexão, respectivamente. Eles também investigaram o comportamento desse mesmo compósito na fadiga e concluíram que as amostras não romperam por fadiga até $10^{6}$ ciclos de tensão abaixo de $6 \mathrm{MPa}$ (metade da tensão máxima) [51].

Outros compósitos desenvolvidos com fibras longas e alinhadas de sisal foram aqueles estudados por Filho et al. [52]. Eles misturaram fibras longas de sisal em uma única camada com fibras discretas de sisal e de coco dispersas na matriz. O foco do estudo era a durabilidade das fibras naturais em matriz cimentícia por meio de ensaios de flexão a quatro pontos após processos diferentes de envelhecimento acelerado. Os problemas de durabilidade foram mitigados após as fibras serem imersas em pasta de sílica ativa. A carga máxima dos corpos de prova de $15 \mathrm{~mm}$ de espessura alcançada foi de $0,8 \mathrm{kN}$ com comportamento strain hardening.

Filho desenvolveu placas quadradas de argamassa que foram reforçadas bidirecionalmente com fibras contínuas e alinhadas de sisal. O compósito foi fabricado com camadas intercaladas de matriz e reforço e cada camada de reforço foi posicionada alternando a orientação das fibras. O comportamento mecânico estudado foi o de punção na placa com a variação de volume de reforço, 4, 6 e $8 \%$. Os melhores resultados foram para as placas com $8 \%$, com carga máxima de $5,16 \mathrm{kN}$ e deslocamento central de 30,26 $\mathrm{mm}$ [53].

Já na forma de tecido único, Hakamy et al. [54] produziram prismas reforçados com tecido de cânhamo e a matriz foi parcialmente substituída por microargila (nanoclay). Prismas com 8 camadas de tecido de cânhamo, resultando em $24 \%$ em peso de reforço, foram ensaiados a flexão a três pontos, chegando até $2 \mathrm{kN}$ de carga máxima. De uma forma geral, adicionando-se microssílica as propriedades mecânicas melhoraram. Com substituição de $1 \%$ do cimento Portland por microssílica o compósito diminuiu sua porosidade $(15,5 \%)$ e aumentou tanto a densidade $(5,3 \%)$ quanto a resistência na flexão $(26,2 \%)$ e tenacidade $(24,9 \%)$ quando comparado com o compósito sem adição de microssílica. Essa adição também promoveu a diminuição de hidróxido de cálcio. Os autores chegaram a conclusão de que a adição de microssílica melhorou a aderência entre o tecido e a matriz.

Com um tecido similar ao do cânhamo visto anteriormente, Fidelis et al. [41] desenvolveram compósitos reforçados com tecidos de juta. Eles compararam 
o comportamento mecânico de três tipos de compósitos: reforçados com três e cinco camadas de tecido sem tratamento e com cinco camadas de tecido tratado por meio de imersão em polímero. Os compósitos foram testados por meio de tração direta e a formação de fissuras foi observada. Apesar da resistência máxima à tração ter sido bem similar para as amostras com 3 camadas (4,38 MPa) e com 5 camadas $(4,73 \mathrm{MPa})$ sem tratamento, estas apresentaram um padrão de fissuração melhor, ou seja, mais quantidade de fissuras com menor espaçamento entre elas. Comparando os compósitos de 5 camadas com as fibras não tratadas e tratadas, os autores observaram um grande acréscimo na resistência máxima (de 4,73 para 6,94 MPa), na capacidade de deformação (de 3,19 para 6,62\%) e na tenacidade desenvolvida.

Claramunt et al. [55] desenvolveram compósitos de matriz cimentícia com substituição parcial de cimento Portland por materiais pozolânicos (microssílica e metacaulim) reforçados com tecido nonwoven de linho. As fibras foram submetidas a tratamentos para diminuir a absorção de água. As amostras reforçadas com 5 camadas foram testadas à flexão a quatro pontos. Os compósitos apresentaram comportamento deflection hardening com resistência máxima de até $12 \mathrm{MPa}$. As adições pozolânicas reduziram o teor de hidróxido de cálcio. A resistência à compressão dessas matrizes se desenvolveu principalmente nos primeiros 28 dias e a resistência à flexão das mesmas, entre os 28 e 56 dias.

\subsubsection{Compósitos reforçados com fibras de curauá}

Como visto, a fibra de curauá possui alta resistência, baixa densidade e alto teor de celulose. Essas características lhe conferem boas propriedades mecânicas para serem exploradas no desenvolvimento de compósitos leves [33]. Usadas para melhorarem as propriedades de diversas matrizes, as fibras de curauá são alvo de estudo para serem empregadas em peças de interior de carros da Volkswagen [20,24], como reforço em painéis de bordo e de portas [22,23].

Alguns pesquisadores exploraram o uso da fibra de curauá alinhada de maneira unidirecional como reforço em matrizes poliméricas [56-58]. A matriz pode variar entre sistemas epóxi, resinas biodegradáveis, como a com base em amido de milho e de poliéster. A fração volumétrica correspondente ao reforço das fibras é bem superior ao usado geralmente nas matrizes cimentícias, sendo 
valores entre 40 e $60 \%$ alcançados devido à forma de moldagem. Métodos de moldagem com compressão a quente são bem explorados. Esse alto volume de fibras permite o compósito alcançar valores de resistência e módulo de elasticidade na flexão e tração de 290 e 327 MPa e 20 e 36 GPa, respectivamente. A aderência também é um fator importante no comportamento mecânico desses compósitos e tratamentos alcalinos para criar mais rugosidade na superfície das fibras são comuns.

Já em matrizes cimentícias, d'Almeida et al. [59] usaram fibras discretas de curauá variando a porcentagem (2, 4 e $6 \%$ em volume) e o comprimento ( 25 e 50 $\mathrm{mm}$ ). Para remediar os problemas de durabilidade, $50 \%$ do cimento Portland foi substituído por metacaulim. Para testar a capacidade mecânica das placas fabricadas foi usado o teste de flexão a quatro pontos. A resistência mais alta foi alcançada pelo compósito com fibras de $25 \mathrm{~mm}$ de comprimento no volume de $2 \%$. A tenacidade mais alta foi obtida com o compósito reforçado com fibras de $50 \mathrm{~mm}$ de comprimento no volume de $4 \%, 2,13 \mathrm{~kJ} / \mathrm{m}^{2}$. Além disso, este último compósito apresentou um comportamento strain hardening bem definido.

Outro estudo envolvendo compósitos cimentícios reforçados com fibras de curauá discretas foi o realizado por Pimentel et al. [42]. Os volumes de fibra usados foram de 2 e $3 \%$ nos comprimentos de 25 e $45 \mathrm{~mm}$. O comportamento mecânico foi avaliado por meio de ensaios de flexão a quatro pontos. Não houve ruptura brusca em nenhum dos casos, e sim um aumento de carga após a primeira fissura. O compósito de maior volume de fibras mais curtas ( $3 \%$ e $25 \mathrm{~mm}$ ) foi o que apresentou maior valor de tensão máxima, $7 \mathrm{MPa}$, e apresentou também os melhores índices de tenacidade, avaliados por diferentes normas.

d'Almeida et al. [60] desenvolveram um compósito onde as fibras de curauá foram usadas em forma de tecido unidirecional como reforço em cinco camadas intercaladas com argamassa. O volume resultante de fibras foi de 6\%. Eles estudaram o efeito da aplicação de pressão de $3 \mathrm{MPa}$ no processo de moldagem e foi concluído não trazer benefício ao comportamento mecânico do compósito, avaliado por testes de flexão a quatro pontos. Comportamento strain hardening foi observado com uma resistência máxima de 27,5 MPa e tenacidade de 29,1 $\mathrm{kJ} / \mathrm{m}^{2}$.

Outro campo que pode ser explorado com as fibras de curauá é o das nanofibras, por elas apresentarem um alto teor de celulose (por volta de $70 \%$, item 
2.1.2). As nanofibras podem ser obtidas por diversos processos e se apresentarem na forma de cristais frágeis de celulose (“nanowhiskers"), nanofibras longas e flexíveis ou até mesmo redes de nanofibras conhecidas por nanofibrilas celulósicas. Processos químicos, equipamentos mecânicos e processos enzimáticos são utilizados para se obter as diferentes formas das nanofibras [20]. Comparando com aplicações convencionais de microfibras, as nanofibras oferecem maior resistência por conta da área de superfície maior que interage com a matriz. Além disso, a densidade é menor (comparada com as microfibras) e elas também podem se apresentar na forma transparente para aplicações óticas [34]. Souza et al. [34] incluíram nanofibrilas de curauá em matriz de álcool polivinílico (PVA) em 4 e $5 \%$. As nanofibrilas tiveram um efeito positivo aumentando em até 144 e 448\% a resistência à tração e o módulo de elasticidade, respectivamente, quando comparado ao PVA puro.

\subsubsection{Matriz cimentícia}

As proporções para mistura de matriz de cimento reforçado com fibra natural não podem ser generalizadas uma vez que existe uma variedade de elementos que podem ser adicionados como pozolanas, agregados finos, adições e aditivos [1].

Fibras naturais em ambiente alcalino, como o da matriz cimentícia, sofrem um processo de envelhecimento que resulta na perda de tenacidade e resistência na pós-fissuração. Esse problema de durabilidade é associado com o aumento de ruptura das fibras e de seu arrancamento [61]. Isso ocorre, principalmente, devido a três fatores: ataque álcali, mineralização da fibra e variação de volume. $O$ ataque álcali causa a decomposição química da lignina e hemicelulose, ambas presentes na lamela média, quebrando a ligação entre as microfibrilas. A mineralização é a migração dos produtos de hidratação, principalmente o hidróxido de cálcio, para a superfície e lúmen da fibra. Essa cristalização diminui a resistência e a flexibilidade da fibra. A variação de volume ocorre pelo alto teor de absorção de água que a fibra possui, enfraquecendo a interface fibra-matriz [61,62].

Diversas estratégias podem ser utilizadas para mitigar o problema de durabilidade das fibras naturais. Pode-se modificar as fibras por meio de impregnação com agentes repelentes e bloqueadores de água e com pasta de micro 
sílica [30,52]. Pode-se também modificar a matriz selando os poros [63] ou diminuindo sua alcalinidade [10,41,52,61,64]. A estratégia de diminuir a alcalinidade geralmente é feita substituindo parte do cimento Portland por materiais pozolânicos, como escória de alto forno [52], microssílica [52], argila calcinada [61], metacaulim [65] e uma mistura de metacaulim com cinza volante $[41,64]$.

A Tabela 2-5 a seguir apresenta as siglas encontradas na literatura para designar elementos comuns da química de materiais cimentícios.

Tabela 2-5 - Símbolos usados na química do cimento.

\begin{tabular}{c|c|c}
\hline Nome & Fórmula & Símbolo \\
Água & $\mathrm{H}_{2} \mathrm{O}$ & $\mathrm{H}$ \\
Óxido de cálcio & $\mathrm{CaO}$ & $\mathrm{C}$ \\
Óxido de silício & $\mathrm{SiO}_{2}$ & $\mathrm{~S}$ \\
Óxido de alumínio & $\mathrm{Al}_{2} \mathrm{O}_{3}$ & $\mathrm{~A}$ \\
Silicato dicálcico & $2 \mathrm{CaOSiO}_{2}$ & $\mathrm{C}_{2} \mathrm{~S}$ \\
Silicato tricálcico & $3 \mathrm{CaOSiO}_{2}$ & $\mathrm{C}_{3} \mathrm{~S}$ \\
Hidróxido de cálcio & $\mathrm{Ca}\left(\mathrm{OH}_{2}\right.$ & $\mathrm{CH}$ \\
Silicato de cálcio hidratado & Estequiometria não & $\mathrm{C}-\mathrm{S}-\mathrm{H}$ \\
& definida & \\
\hline
\end{tabular}

O hidróxido de cálcio e o silicato de cálcio hidratado são produtos formados na hidratação dos silicatos presentes no cimento Portland: silicato tricálcico (alita) e bicálcico (belita). A reação de hidratação dos silicatos se encontra nas Equações 1 (alita) e 2 (belita) [2].

$$
\begin{gathered}
2 \mathrm{C}_{3} \mathrm{~S}+7 \mathrm{H} \rightarrow \mathrm{C}-\mathrm{S}-\mathrm{H}+3 \mathrm{CH} \\
2 \mathrm{C}_{2} \mathrm{~S}+7 \mathrm{H} \rightarrow \mathrm{CSH}+\mathrm{C}-\mathrm{S}-\mathrm{H}+\mathrm{CH}
\end{gathered}
$$

Os materiais pozolânicos possuem um alto teor de compostos silicosos/aluminosos amorfos que consomem o $\mathrm{CH}$ formando C-S-H (Equação 3), C-A-H (Equação 4) e/ou C-A-S-H (Equação 5), em ambiente alcalino

$$
\begin{aligned}
C H+S+H & \rightarrow C-S-H \\
C H+A+H & \rightarrow C-A-H \\
C H+A+S+H & \rightarrow C-A-S-H
\end{aligned}
$$


Essas reações mantêm a matriz com baixo teor de hidróxido de cálcio e essa estratégia se mostrou eficiente no combate ao processo de envelhecimento das fibras naturais $[52,61,65]$.

De maneira geral, adicionar fibras em uma matriz de concreto resulta em perda de consistência por conta do aumento da área de superfície e absorção de água das fibras. Essa perda de consistência é influenciada pela razão de aspecto da fibra e pela quantidade da mesma. Apesar disso, manter a trabalhabilidade é importante, seja para garantir a compactação adequada quando usada com fibras discretas, seja para penetrar entre os fios de tecidos. Uma opção é tratar as fibras anteriormente para reduzir a absorção de água ou molhá-las antes de adicionar na matriz. Além disso, a absorção de água pode ser levada em consideração quando da elaboração do traço da matriz [1].

No trabalho desenvolvido por Mansur e Aziz, a trabalhabilidade da matriz com fibras curtas de juta não foi determinada quantitativamente, mas foi observado que a mesma diminuía com o aumento do comprimento das fibras utilizadas [66]. O mesmo efeito foi observado quando uma matriz de cimento Portland foi reforçada com fibras curtas de coco. Quanto maior o volume de fibras, maior foi a dosagem do superplastificante para se obter uma mesma trabalhabilidade [67].

Além desse problema na consistência, outro aspecto que deve ser levado em consideração quando da utilização de fibras naturais em matriz cimentícia é a "pega" (tempo para endurecimento) retardada [1]. Segundo Bilba et al. [68] e Stancato et al [69], os componentes de glicose, hemicelulose e lignina podem retardar a hidratação do cimento. E, segundo Sedan et al. a explicação para isso pode ser que a pectina pode adsorver o cálcio prevenindo a formação de C-S-H [70]. A ASTM sugere ainda o uso de cimento Portland do Tipo III (alta resistência inicial) para ajudar na pega [1].

\subsection{Autocicatrização autônoma}

A autocicatrização dos materiais cimentícios é basicamente a capacidade que o material possui de fechar suas fissuras e ter, ainda, algum reganho de propriedades mecânicas e/ou físicas. A terminologia é discutida entre vários autores e associações. Nesta dissertação será adotada a nomenclatura base 
proposta pelo RILEM (Reunion Internationale des Laboratoires et Experts des Materiaux, Systemes de Construction et Ouvrages) 221-SHC, que compreende, dentre outras:

- Autocicatrização: processo pelo qual o material passa por uma recuperação e melhora em seu desempenho após uma ação que tenha reduzido o mesmo.

- Autocicatrização autógena: o processo de autocicatrização é dito autógeno quando a recuperação vem de componentes que já estariam presentes no material mesmo que este não tivesse sido projetado especificamente para ocorrer a autocicatrização.

- Autocicatrização engenheirada: este processo de autocicatrização ocorre quando a recuperação vem de componentes que foram inseridos intencionalmente para desencadearem o fenômeno de fechamento das fissuras.

Há ainda o termo "autovedação" que se aplica quando há apenas o fechamento das fissuras sem o reganho de nenhuma outra propriedade.

Neste trabalho, será realizado o estudo da capacidade de autocicatrização autógena do material desenvolvido. Ou seja, a capacidade de fechamento das fissuras com reganho de propriedades mecânicas graças às propriedades intrínsecas ao material, sem nenhum outro componente adicionado para este fim.

Por possuir propriedades intrínsecas que levam ao fechamento natural, a autocicatrização de fissuras em materiais cimentícios é um fenômeno antigo e bem conhecido, sendo reconhecido pela Academia Francesa de Ciência em 1836 por observações em reservatórios, bueiros e tubulações [71,72]. A partir disso, estudos sobre a permeabilidade do concreto [73] assim como sobre a autocicatrização foram desenvolvidos e contribuíram para melhor entendimento do fenômeno [74], fazendo com que ele chamasse a atenção de pesquisadores que começaram a explorar diversas abordagens sobre o tema.

Há várias formas de se mensurar a capacidade de autocicatrização de uma amostra. Alguns autores se concentram na parte de transporte de fluidos, utilizando testes de penetração de água $[75,76]$ e de cloreto [77-80] e absorção [75,78,81]. Já outros focam nas propriedades mecânicas com testes de tração [75,82] e testes de flexão [83-85]. Além de analisar qualitativamente por meio de análises em microscópio estereoscópico [84-86]. 


\subsubsection{Mecanismos de autocicatrização.}

A autocicatrização de fissuras em materiais cimentícios é uma combinação complexa de processos químicos e físicos e pode ser atribuída a vários fatores. Podem-se destacar cinco mecanismos e, na maioria dos casos, dois ou mais desses mecanismos podem acontecer simultaneamente $[71,87]$.

Os dois principais mecanismos são a formação de hidróxido de cálcio $\left(\mathrm{Ca}(\mathrm{OH})_{2}\right)$, que precisa de água, e a formação de carbonato de cálcio $\left(\mathrm{CaCO}_{3}\right)$, que além de água, necessita da presença de dióxido de carbono [88]. Como visto, o hidróxido de cálcio é um dos produtos de hidratação do cimento (Equações 1 e 2 , item 2.2.2).

O mecanismo fundamental para formação de carbonato de cálcio se dá da seguinte forma: o dióxido de carbono é dissolvido em água (Equação 6) formando o ácido carbônico que pode se desassociar de duas maneiras (Equações 7 e 8); o hidróxido de cálcio se dissipa ao longo das superfícies das fissuras, sendo fonte de íons de cálcio; esses íons estão livres para reagirem com o produto da dissolução do ácido carbônico, formando o carbonato de cálcio (Equações 9 e 10). A reação representada na Equação 9 acontece somente quando o pH está acima de 8 enquanto que a 10 acontece quando o nível do pH está entre 7,5 e 8 [89].

$$
\begin{gathered}
\mathrm{H}_{2} \mathrm{O}+\mathrm{CO}_{2} \leftrightarrow \mathrm{H}_{2} \mathrm{CO}_{3} \\
\mathrm{H}_{2} \mathrm{CO}_{3} \leftrightarrow \mathrm{H}^{+}+\mathrm{HCO}_{3}^{-} \\
\mathrm{H}_{2} \mathrm{CO}_{3} \leftrightarrow 2 \mathrm{H}+\mathrm{CO}_{3}^{2-} \\
\mathrm{Ca}^{2+}+\mathrm{CO}_{3}^{2-} \leftrightarrow \mathrm{CaCO}_{3} \\
\mathrm{Ca}^{2+}+\mathrm{HCO}_{3}^{-} \leftrightarrow \mathrm{CaCO}_{3}+\mathrm{H}^{+}
\end{gathered}
$$

O terceiro mecanismo destacado é o bloqueio das fissuras por meio de deposição de detritos ou impurezas, no qual não há recuperação de propriedades mecânicas [88]. Pode-se considerar ainda a hidratação tardia de grãos de material cimentícios que não reagiram quando da concretagem e a expansão de produtos de hidratação, como a dilatação do C-S-H [90]. 
A contribuição que cada um desses mecanismos tem no processo de autocicatrização permanece em debate. Numa pesquisa realizada por Edvardsen C. Water [74] foi relatado que o bloqueio por deposição de detritos e a expansão de produtos de hidratação são de contribuição mínima. Aparentemente, o mecanismo com a maior eficiência na autocicatrização depende da idade do concreto no momento em que ocorrem as fissuras. A hidratação tardia se apresenta como o principal mecanismo em concretos jovens por ainda possuir muitos grãos não hidratados enquanto que para uma idade mais avançada, o mecanismo que tem a maior influência é a precipitação de cristais de carbonato de cálcio. Apesar das diferentes opiniões, pesquisadores concordam que a presença de água é essencial para que ocorra a autocicatrização [74,88].

O processo de autocicatrização ocorre entre superfícies de fissuras estreitas. A amplitude máxima que uma fissura pode ter para ser completamente fechada por meios autógenos foi objeto de estudo de diversos autores [91], que obtiveram resultados diversos entre si. Apesar disso, as pesquisas apontam que quanto mais estreitas forem as fissuras, o fechamento das mesmas é mais provável de ocorrer. Em geral, fissuras de até $50 \mu \mathrm{m}$ são capazes de serem fechadas desde que haja a presença de água e íons (seja na forma de $\mathrm{Ca}^{2+}, \mathrm{CO}_{2}$ ou partículas não hidratadas). Fissuras maiores do que $150 \mu \mathrm{m}$ já se mostram mais difíceis de serem fechadas $[84,85,87,92]$.

\subsubsection{Estratégias para se obter autocicatrização}

A pesquisa deste trabalho gira em torno da capacidade de autocicatrização autógena do compósito desenvolvido. Apesar disso, neste item são apresentadas algumas abordagens de como se tem feito para promover o fechamento de fissuras por meio de inserções de componentes no material (autocicatrização engenheirada).

Como visto, uma característica positiva dos materiais cimentícios é possuir propriedades intrínsecas que levam a autocicatrização. Porém, a ocorrência e eficiência desses mecanismos são incertas. Assim, algumas interferências podem melhorar tais propriedades, como:

i) Fornecimento de água, já que os principais processos da autocicatrização são realizados na presença de água. 
ii) Melhorar a possibilidade de hidratação e cristalização contínua, levando a formação de produtos de hidratação e de carbonato de cálcio.

iii) Restrição da amplitude das fissuras, visto que é necessário menos produto para fechar as fissuras mais estreitas.

\subsubsection{Fornecimento de água}

A água é necessária tanto para a hidratação contínua quanto para a formação de carbonato e hidróxido de cálcio. Não é certo que umidade suficiente para as reações estará disponível, então, seria interessante que a própria matriz a pudesse fornecer. Uma classe promissora de materiais que permite que haja disponibilidade de água dentro da matriz é a dos polímeros superabsorventes (SAP - superabsorbent polymer) [84,92].

Os SAP's, também conhecidos como hidrogel, são polímeros reticulados que possuem a capacidade de absorver uma grande quantidade de líquido, se expandindo em forma de gel insolúvel. O quanto o hidrogel consegue expandir depende da alcalinidade e da concentração iônica da solução. Assim, quando o hidrogel é adicionado na matriz cimentícia ainda na fase líquida, o $\mathrm{pH}$ da água presente é bem alto, levando a um nível de dilatação menor se comparado com água pura [93]. Enquanto o cimento sofre hidratação, o hidrogel libera a água absorvida gradualmente, encolhendo de tamanho, deixando pequenos poros. Quando a fissura é desencadeada na matriz, é provável que ela se propague através desses poros onde se encontram os hidrogels, já que deixam falhas. No momento em que o hidrogel é exposto ao ambiente através da fissura, a umidade ou um fluido de baixa concentração iônica (chuva, por exemplo) entra em contato, o hidrogel se expandirá além de seu poro original, proporcionando o bloqueio físico entre as fissuras. Ainda, em períodos de secagem, o hidrogel pode voltar a liberar água para hidratação de algum grão presente na superfície da fissura, promovendo, assim, a hidratação tardia.

Várias pesquisas investigam o uso dos SAP's para melhorar o fechamento das fissuras, explorando tanto o grau de dilatação ligado a alcalinidade do meio quanto as consequências relativas às reservas de água [93-95]. Lee et al. [93] prepararam amostras contendo quantidades diferentes de SAP e carregaram as mesmas até formarem fissuras e foram submetidas a uma solução que simulava a 
infiltração de águas subterrâneas. No caso de fissuras de até $0,3 \mathrm{~mm}$, o fluxo foi reduzido em até $85 \%$. Eles concluíram que, aumentando a dosagem de SAP, acelera-se o processo de fechamento das fissuras, porém isso causa uma grande redução da resistência, limitando seu uso. Em outra pesquisa, foi verificado que a perda de resistência pode chegar até $52 \%$ se a quantidade de SAP utilizada for tal que proporcione o melhor resultado no fechamento das fissuras [94]. Para diminuir o impacto na resistência, Mignon et al. [95] usaram biopolímeros que reduziram somente $15 \%$ da resistência à compressão com a adição de $1 \%$ em massa de SAP.

Outro grupo atuante na pesquisa dos SAP's como promotores da autocicatrização é aquele liderado por Nelie de Belie [71,84,92,94-97]. Eles geralmente juntam características do SHCC (conceito visto em 2.2) com os benefícios dos SAP's. Em um desses estudos, foram usados dois tipos de SAP e uma amostra sem SAP para controle. Apesar das amostras com SAP apresentarem melhores resultados de fechamento de fissuras (feito qualitativamente através de estereoscópio) do que as sem SAP, só a presença deles não foi suficiente para tornar a água externa indispensável. Isso foi verificado com diferentes tipos de exposição: ciclos de molhagem e secagem e deixando em câmara úmida (UR>90\%) [84]. Uma pesquisa conduzida para de investigar o uso de SAP's em grande escala $(150 \times 250 \times 3000 \mathrm{~mm})$ foi realizada por esse grupo [97]. Eles utilizaram diversas técnicas para avaliar a autocicatrização, como DIC, tomografia de raio-X, transdutores de emissão acústica, microscopia e luz fluorescente. Apesar de ser mais difícil de observar o fechamento, ele é verificado e se torna mais latente para as amostras com SAP por apresentarem fissuras menores.

\subsubsection{Hidratação e Cristalização}

Além de introduzir água na matriz, outra maneira de estimular a hidratação contínua e a formação de carbonato de cálcio é adicionar agentes que promovem a deposição de cristais nas fissuras.

Isso pode ser feito deixando grãos não hidratados na matriz: uma vez que a fissura está formada, a água (ou umidade) chega à região reagindo com os grãos e formando produtos de hidratação que preenchem a fissura. Alguns pesquisadores adicionam materiais pozolânicos que são muito finos e podem permanecer não 
hidratados ao longo do tempo. Como exemplo, Şahmaran et al. [98] substituíram 35 e $55 \%$ do cimento Portland por cinzas volantes e constatou que para materiais com alto teor de cinzas volantes a perda inicial de resistência é maior do que para matrizes sem substituição. Apesar disso, após pré-fissuração e imersão em água por um mês, a recuperação mecânica das amostras com cinzas volantes chegou a ser $10 \%$ maior. Resultados semelhantes foram obtidos para os ensaios de permeabilidade.

Outra estratégia é usar agentes expansivos. Quando a água entra na fissura, o agente expansivo aumenta de tamanho e agentes químicos promovem a precipitação de cristais que fecham a fissura. Sisomphon et al. [99] usaram uma combinação de aditivo expansivo com base em sulfoaluminato de cálcio combinado com mistura cristalina (sílica reativa e catalizantes). Discos com diversas proporções de materiais foram produzidos e pré-fissurados em até 400 $\mu \mathrm{m}$. A autocicatrização foi mensurada com testes de permeabilidade e visualmente. Após 28 dias submersos em água, as amostras contendo agentes químicos apresentaram zero permeabilidade, com cristais concentrados na parte mais externa da fissura, onde a concentração de íons de $\mathrm{Ca}^{2+}$ é maior. Apesar disso, microfissuras foram detectadas na interface dos agentes por conta das reações expansivas.

Uma desvantagem em usar as abordagens citadas até agora é que, uma vez que o grão reage ou o cristal é formado, o agente de cura é consumido no processo. Para combater isso, uma linha de pesquisa (liderada por Jonkers e Schlangen) foi desenvolvida com foco em bactérias que precipitam $\mathrm{CaCO}_{3}[100$ 104]. Por elas apenas mediarem o processo e não serem convertidas, o uso das bactérias é uma estratégia promissora para a ocorrência da autocicatrização [101]. Após anos de pesquisas, chegou-se em uma bactéria capaz de sobreviver ao ambiente altamente alcalino de uma matriz cimentícia encapsulada em esporos separadamente do seu substrato para não morrerem quando da precipitação dos cristais de carbonato de cálcio. Esporo é uma camada que protege a bactéria e é responsável pela resistência ao ataque de agentes físicos e químicos. A formação dos cristais é basicamente a conversão metabólica das bactérias quando elas consomem o substrato orgânico presente no segundo esporo. Para testar essa capacidade, discos foram produzidos com ambos os esporos integrados na matriz 
e pré-fissurados. As amostras foram colocadas em um arranjo experimental de permeabilidade e, após 24 horas com uma das faces em contato com a água, as fissuras foram totalmente fechadas com permeabilidade tendendo a zero [100]. Há ainda dois problemas principais com essa estratégia. O primeiro é que com a adição dos esporos, o material perde cerca de $25 \%$ de sua resistência à compressão. A outra é o custo que ainda é maior do que o concreto convencional [102]. Apesar disso, o uso dessas bactérias é o mais promissor possível, sendo, inclusive já utilizado em recuperação de permeabilidade em pavimentos na Holanda [105].

\subsubsection{Restrição da abertura das fissuras}

Como mencionado, a probabilidade de sucesso da autocicatrização é maior quanto mais estreitas forem as fissuras. Com isso em mente, alguns pesquisadores começaram a incorporar materiais funcionais como ligas com memória de forma (SMA - shaping memory alloys) e polímeros com memória de forma (SMP shaping memory polymers) para fechar mecanicamente as fissuras.

O conceito básico desses materiais é que eles possuem um formato memorizado; quando as fissuras se formam, eles se deformam fazendo a ligação entre as fissuras, alterando sua forma; quando são submetidos a uma alta temperatura, eles tendem a voltar ao formato original, menor do que o submetido, se contraindo e aplicando uma força que faz com que as fissuras se fechem, voltando ao estado original do elemento [89].

Várias ligas foram testadas como Ouro-Cádmio, Cobre-Alumínio-Manganês e Níquel-Titânio, conhecida como nitinol. Estudos mostraram que, com a devida protensão, as SMA's podem melhorar a capacidade de dissipação de energia do elemento de concreto, reduzindo a largura das fissuras residuais e a deformação do mesmo [106]. Xiaopeng el al. [107] estudaram quatro diferentes tipos de materiais com ligas de $\mathrm{Ni}-\mathrm{Ti}$ sob testes cíclicos, incluindo um compósito que apresentou $40 \mu \mathrm{m}$ como média de largura das fissuras. Para este material, após sete ciclos de ensaios de flexão, todas as fissuras foram fechadas mecanicamente pelas ligas de Ni-Ti. Neste caso, não foi avaliado o reganho de propriedades mecânicas. 
Apesar dos excelentes resultados que as pesquisas com SMA's vêm apresentando acerca do fechamento das fissuras [71,106], o custo para a utilização delas é praticamente inviável, exceto para casos específicos. Numa tentativa de manter o conceito desses materiais, porém diminuindo o preço para eles serem viáveis para um número maior de aplicações, foram desenvolvidos os SMP. Jefferson et al. [108], usando polímero do tipo PET Shrinktite, conseguiram fechar fissuras de até $300 \mu \mathrm{m}$.

\subsubsection{Autocicatrização autógena em materiais que apresentam comportamento strain-hardening.}

Foi visto no item 2.3.2.3 que há estratégias para fechar mecanicamente as fissuras de um elemento. Outra abordagem que se beneficia do conceito de restrição da amplitude das fissuras são os compósitos que desenvolvem um comportamento strain-hardening (SHCC - strain-hardening cementitious composites). Como visto no item 2.2, as microfissuras podem ser vistas como uma propriedade intrínseca desses materiais, proporcionando melhores condições para ocorrência da autocicatrização autógena. Além de apresentarem pequenas fissuras (da ordem de $80 \mu \mathrm{m}$ ), esses compósitos geralmente possuem muitos materiais finos em sua composição, aumentando a quantidade de grãos não hidratados na matriz.

Um exemplo de estudo de autocicatrização autógena foi realizado por Yang et al. [82]. Neste estudo, dois compósitos foram fabricados: um para que houvesse comportamento strain hardening e outro com comportamento strain softening, de forma que diferentes tamanhos de fissuras fossem avaliados. Após seis meses de cura, os compósitos do tipo SHCC foram pré-carregados até cinco níveis diferentes de deformação. Após todas as amostras serem pré-fissuradas, elas foram expostas a duas condições de exposição: 24 horas submersas em água seguidas por 24 horas em ar a $21^{\circ} \mathrm{C}$ e 24 horas submersas em água seguidas por 22 horas em forno a $55^{\circ} \mathrm{C}$. Para mensurar os efeitos da autocicatrização autógena, os autores utilizaram frequência de ressonância, testes de permeabilidade e testes de tração direta. Segundo os testes de ressonância e de permeabilidade, para fissuras de até $50 \mu \mathrm{m}$ a recuperação foi completa. O nível de recuperação em fissuras a partir de $50 \mu \mathrm{m}$ diminuiu e, em fissuras de $150 \mu \mathrm{m}$, não houve recuperação. $\mathrm{O}$ 
efeito da exposição a $55^{\circ} \mathrm{C}$ foi observado principalmente no teste mecânico. Foi verificado que, apesar da resistência ter sido ligeiramente maior quando exposto a $55^{\circ} \mathrm{C}$, o nível de deformação decresceu significativamente, quando comparado com as amostras de controle. De maneira geral, quanto menor as fissuras, maior sua recuperação e, mesmo em altos níveis de pré-carregamento (3\% de deformação), as características dúcteis do material foram conservadas.

A fim de explorar o uso de cinza volante para autocicatrização autógena, Kan e Shi compararam dois compósitos: um com $33 \%$ e outro com $44 \%$ de cinzas volantes. Amostras com 3, 7, 28, 56 e 90 dias foram pré-fissuradas em 0,3, 0,5, 1 e $2 \%$ de deformação em ensaio de tração e expostas a ciclos de 24 horas de imersão em água e 24 horas em ambiente com umidade relativa de 50\%. Foi observado que, para as amostras com maior teor de cinza volante, o número de fissuras foi maior e a média do tamanho delas foi menor. Amostras pré-carregadas a $2 \%$ após 10 ciclos tiveram reganho avaliado por frequência de ressonância: 75 e $85 \%$ para as amostras com 33 e $44 \%$ de cinza volante, respectivamente. Com análise de Espectroscopia por Dispersão de Energia de Raios X (EDS), as proporções de cálcio:sílica e oxigênio:cálcio foram verificadas para os produtos

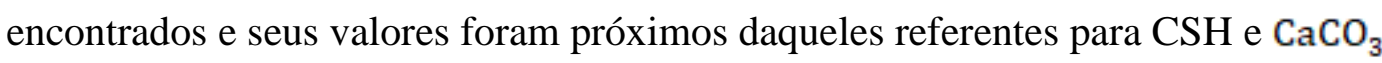
[109]. Resultados similares foram encontrados por Zhang et al. [81] com outros volumes de cinza volante.

Qian et al. [110] desenvolveram um material com características similares ao Yang et al. [75], mas com escória de alto forno e pó de calcário como substitutos parciais do cimento Portland. A pré-fissuração se deu por flexão a quatro pontos até $2,4 \mathrm{~mm}$ de deflexão e condicionamento ao ar e em água para efeitos de comparação. As amostras submetidas a água tiveram recuperação da capacidade de deflexão de $105 \%$ enquanto que, para as amostras submetidas ao ar, somente $65 \%$. Para os valores de rigidez, o reganho foi de 60 e $40 \%$, para as amostras submetidas a água e ao ar, respectivamente.

No âmbito do uso das fibras naturais para facilitar a autocicatrização autógena, Snoeck et al. [85] desenvolveram compósitos com fibras curtas de linho tratadas a $2 \%$ com hidróxido de sódio, resultando em comportamento strain hardening. $\mathrm{O}$ fechamento das fissuras foi monitorado por microscópio estereoscópio. As amostras foram carregadas em ensaio de flexão a quatro pontos 
até a tensão máxima e submetidas a ciclos de molhagem e secagem (12 horas de imersão em água seguidas por 12 horas em ambiente com umidade relativa de $60 \%$ ) por 14 dias. Um compósito de controle foi desenvolvido com fibras de PVA e usado para verificar diferenças entre fibras sintéticas e naturais. Eles concluíram que o fechamento das fissuras independe do tipo de fibra utilizada mas depende, sim, do tamanho da fissura que o compósito apresenta. Fissuras com até $30 \mu \mathrm{m}$ foram totalmente fechadas. Fissuras com até $150 \mu \mathrm{m}$ foram fechadas parcialmente e, para valores além deste, nenhum reganho foi observado. Apesar disso, o reganho de propriedades mecânicas (resistência na primeira fissura, resistência máxima, deformação e módulo de elasticidade) foi maior para as amostras com PVA. Resultados semelhantes podem ser encontrados por Snoeck e Belie [96].

Ferrara et al. [14] compararam a capacidade de autocicatrização autógena de compósito reforçado apenas com fibras de aço e com outro híbrido de fibras de aço e sisal. Para cada tipo de reforço foram desenvolvidos dois tipos de compósitos: um com comportamento strain hardening e outro com comportamento strain softening. Os dois tipos de compósitos foram fabricados a fim de ter diferentes tamanhos de fissuras. Três níveis de pré-fissuração foram feitos para o compósito do tipo SHCC e apenas um para o outro compósito por meio de ensaio de flexão a quatro pontos. Os corpos-de-prova foram submetidos a quatro condicionamentos: imersão em água, exposição a ambiente com 50\% de umidade relativa, exposição a ambiente com $90 \%$ de umidade relativa e ciclos de molhagem e secagem de 24 horas. Após três meses submetidos ao condicionamento cíclico, algumas fissuras das amostras contendo sisal foram fechadas. Após seis meses submetidas ao mesmo condicionamento, foi observado apenas a diminuição do tamanho de algumas fissuras das amostras sem sisal. 


\section{Desenvolvimento e Caracterização dos Materiais}

\subsection{Introdução}

O comportamento desejado do compósito desenvolvido envolve a formação de múltiplas microfissuras quando solicitado a tensões de tração. Para isso, deve haver sinergia adequada entre matriz e reforço fazendo com que a transferência de tensões ocorra satisfatoriamente. Isso é alcançado quando se tem uma boa adesão química entre os materiais [4]. Assim, a matriz deve ser fluida o suficiente para a maior penetração possível da mesma entre as fibras longas e alinhadas de curauá e consistente para sustentar as fibras como reforço interno.

Outra questão que deve ser levada em conta ao produzir compósitos cimentícios reforçados com fibras naturais é a durabilidade. Fibras naturais em ambiente alcalino, como o da matriz cimentícia, sofrem um processo de envelhecimento que resulta na perda de tenacidade e resistência na pós fissuração, como visto no item 2.2.2. Portanto, para garantir a durabilidade dos compósitos desenvolvidos neste trabalho, uma matriz cimentícia com baixo teor de hidróxido de cálcio foi utilizada. Para isso, metade do cimento foi substituído por materiais pozolânicos (metacaulim e cinza volante) tendo como base a matriz utilizada por Diaz [64].

\subsection{Matriz cimentícia}

\subsubsection{Materiais}

Os materiais secos utilizados para produzir a matriz cimentícia foram: Cimento Portland CPII F-32 fabricado pela empresa Lafarge; metacaulim da Metacaulim do Brasil Industria e Comercio Ltda; cinza volante distribuída pela Pozofly (Santa Catarina); e areia de rio com diâmetro máximo de 1,18mm. O superplastificante Glenium 51 (MS) com teor de sólidos de $32 \%$ foi usado na proporção de $2,5 \%$ do peso dos materiais cimentícios para oferecer a trabalhabilidade necessária para a moldagem dos compósitos. 
O cimento Portland CPII F-32 é aquele que tem em sua composição clínquer e sulfatos de cálcio correspondentes entre 90 e $94 \%$ e materiais carbonáticos (materiais finamente divididos em sua maior parte composto de carbonato de cálcio) correspondentes entre 6 e 10\%, segundo a NBR 11578/91. A composição química do metacaulim se encontra na Tabela 3-1 a seguir. Os dados foram fornecidos pelo fabricante para o lote usado.

Tabela 3-1 - Composição química e massa específica do metacaulim.

\begin{tabular}{c|c}
\hline \multicolumn{2}{c}{ Composição química do } \\
metacaulim \\
$\mathrm{SiO}_{2}$ & $59,0 \%$ \\
$\mathrm{Al}_{2} \mathrm{O}_{3}$ & $32,9 \%$ \\
$\mathrm{Fe}_{2} \mathrm{O}_{3}$ & $1,9 \%$ \\
$\mathrm{TiO}_{2}$ & $0,9 \%$ \\
$\mathrm{CaO}$ & $0,3 \%$ \\
$\mathrm{MgO}$ & $0,3 \%$ \\
$\mathrm{~K}_{2} \mathrm{O}$ & $1,9 \%$ \\
$\mathrm{Na}_{2} \mathrm{O}$ & $0,1 \%$ \\
$\mathrm{SO}_{3}$ & $0,1 \%$ \\
Massa & $2,56 \mathrm{~g} / \mathrm{cm}^{3}$ \\
específica & \\
\hline
\end{tabular}

Areia de rio lavada foi utilizada como agregado miúdo com granulometria passante na peneira $1,18 \mathrm{~mm}$ e retida na de abertura $0,15 \mathrm{~mm}$. Esta granulometria foi escolhida para obter uma boa compatibilidade com os materiais cimentícios já mencionados. A granulometria do agregado miúdo foi determinada com o auxílio de um agitador mecânico, da marca Mesh, em peneiras de abertura: 0,15;0,30; 0,60 e 1,18 mm com uma amostra de 1000 gramas. A curva de distribuição granulométrica da areia é mostrada na Figura 3-1.

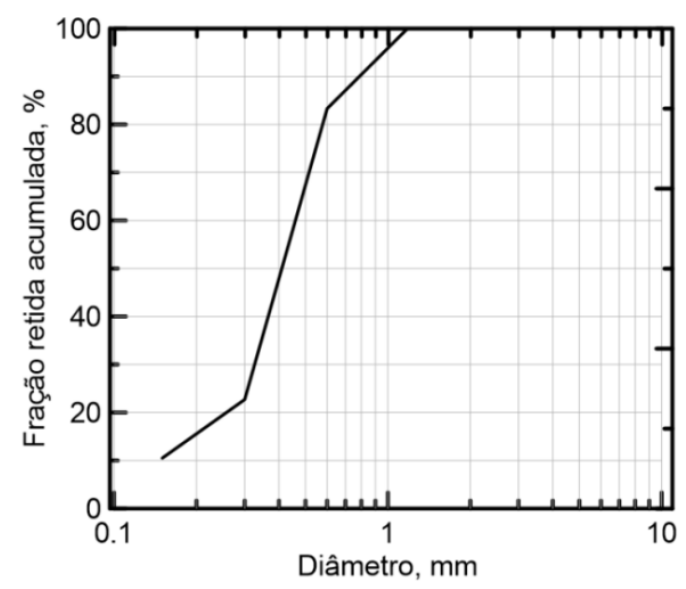

Figura 3-1 - Granulometria da areia fina utilizada. 


\subsubsection{Dosagem e Processamento}

O traço adotado foi 1:1:0,4 (areia:materiais cimentícios:água), sendo o mesmo adotado por Diaz [64]. A quantidade de superplastificante, 2,5\% em massa dos materiais cimentícios, foi alterada para dar maior fluidez à matriz. $\mathrm{O}$ cimento representa $50 \%$ da massa dos materiais cimentícios, o metacaulim $40 \%$ e a cinza volante representa $10 \%$, em massa. A argamassa foi misturada em argamassadeira planetária com capacidade de 5 litros da seguinte forma:

i) a areia foi misturada com metade da água por 1 minuto em velocidade de $136 \mathrm{rpm}$;

ii) adição dos materiais cimentícios e da água restante, misturando por 30 segundos a $136 \mathrm{rpm}$;

iii) o superplastificante foi adicionado lentamente, distribuindo por todo o recipiente, e homogeneizado com os outros materiais por 4 minutos a $281 \mathrm{rpm}$.

A Figura 3-2 mostra o processo de mistura dos materiais.

(a)

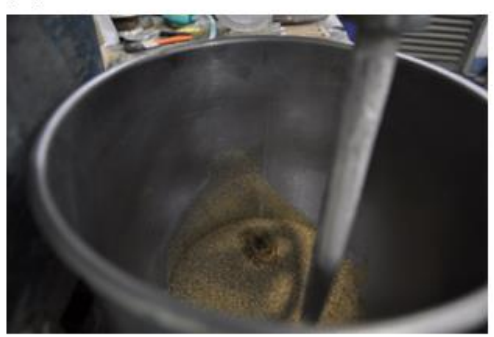

(c)

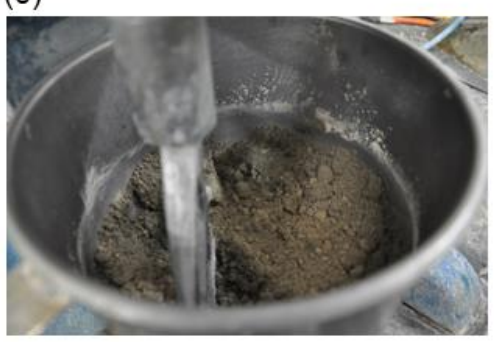

(b)

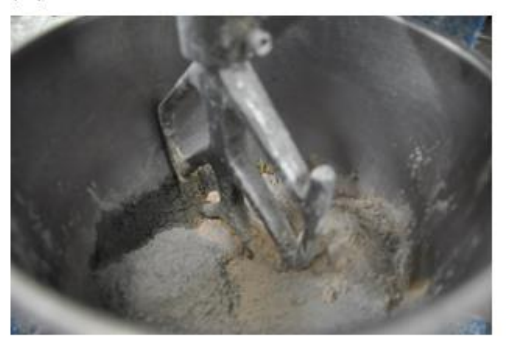

(d)

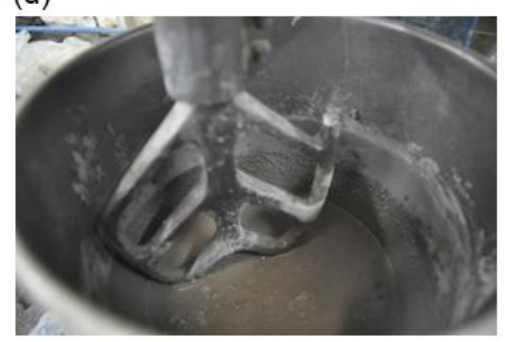

Figura 3-2 - Etapas da mistura da argamassa: (a) areia com metade da água; (b) materiais cimentícios; (c) argamassa antes de adicionar o superplastificante e (d) após adicionar o superplastificante.

\subsubsection{Propriedades da matriz no estado fresco}

Como já mencionado, a trabalhabilidade da matriz é de grande interesse, pois ela precisa ter fluidez tal que consiga penetrar por entre o tecido unidirecional 
de fibras de curauá. A consistência da matriz foi determinada a partir do ensaio de espalhamento segundo a ASTM C230/C230M (2014), modificado para as dimensões do molde disponível. Utilizou-se uma mesa horizontal lisa e plana e um molde com formato de tronco cônico de metal de dimensões $12,5 \mathrm{~mm}$ x 8,0 $\mathrm{mm} \times 5,5 \mathrm{~mm}$ (base maior $\mathrm{x}$ base menor $\mathrm{x}$ altura). A mistura foi colocada no cone até a borda do tronco. Depois de cheio, o molde foi retirado, deixando que a mistura se espalhasse na mesa. Esperou-se até que não houvesse diferença de mais de $5 \mathrm{~mm}$ entre duas medidas consecutivas de diâmetro. A consistência foi então determinada como a média aritmética de dois diâmetros ortogonais, e o valor obtido foi de $400 \mathrm{~mm}$. A Figura 3-3 apresenta o processo de determinação da consistência da matriz e um detalhe da borda, mostrando que não houve segregação do agregado.

(a)

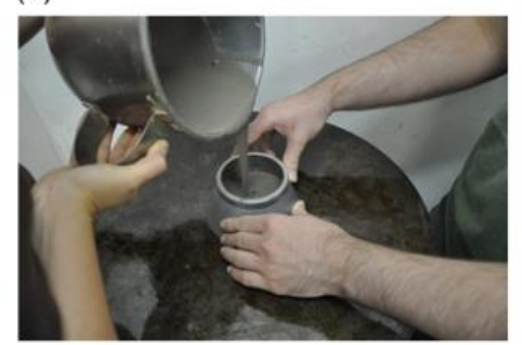

(c)

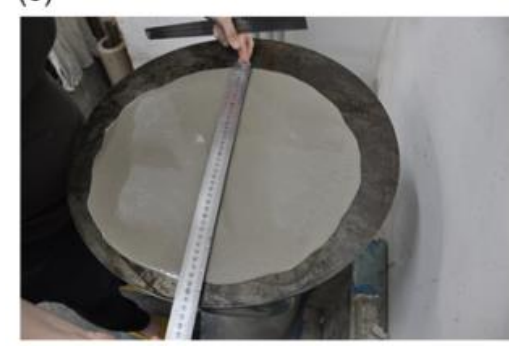

(b)

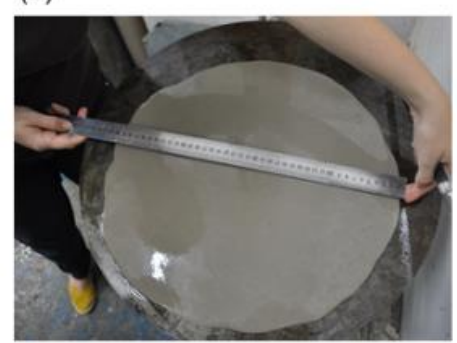

(d)

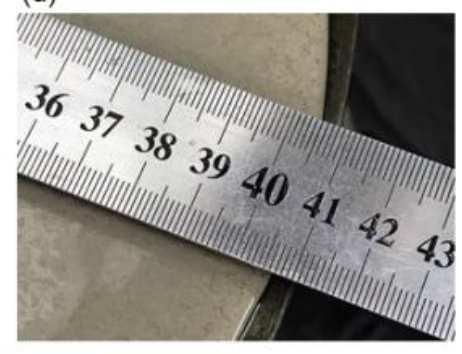

Figura 3-3 - Etapas do espalhamento: (a) argamassa sendo colocada no tronco de cone; (b) medida do primeiro diâmetro; (c) medida do segundo diâmetro e (d) detalhe da borda, na qual é possível observar não haver segregação de materiais.

\subsubsection{Propriedades da matriz no estado endurecido}

A matriz desenvolvida foi testada à compressão para determinar a sua resistência. Os ensaios foram realizados em três idades diferentes a fim de entender a cinética de hidratação dos materiais pozolânicos. Os ensaios de compressão axial foram realizados em um equipamento universal de ensaios 
mecânicos MTS, modelo 810/500, com capacidade de carga de 500 kN, aos 14, 28, 42 e 125 dias. Para cada idade foram produzidos três corpos de prova cilíndricos em um molde metálico com $100 \mathrm{~mm}$ de altura e $50 \mathrm{~mm}$ de diâmetro. Eles foram desmoldados com 24 horas e curados em água até um dia antes do ensaio, quando foram faceados, a fim de se obter a regularização da superfície, evitando concentração de tensões e excentricidades. A taxa de deslocamento adotada nos ensaios de compressão foi de $0,4 \mathrm{~mm} / \mathrm{min}$. Os deslocamentos verticais foram medidos por dois transdutores de deslocamento verticais (LVDTs), com comprimento de $7 \mathrm{~mm}$, acoplados a anéis acrílicos posicionados ao redor do corpo de prova. O valor do deslocamento considerado foi o valor médio dos deslocamentos obtidos pelos LVDTs. A Figura 3-4 ilustra o arranjo experimental do ensaio.

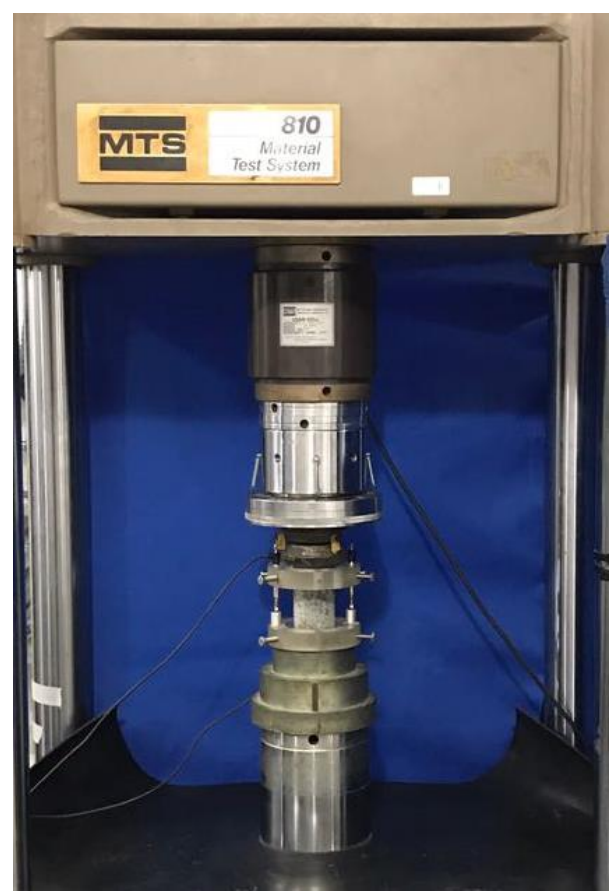

Figura 3-4 - Arranjo experimental do ensaio de compressão.

Para o cálculo da resistência, os valores de força foram divididos pela área da seção transversal do corpo de prova: área $=\pi \times \mathrm{r}^{2}$, onde $\mathrm{r}$ é o valor do raio do corpo de prova cilíndrico. Os valores de deformação foram calculados dividindo o deslocamento considerado (média dos LVDTs) pelo comprimento que os LVDTs cobriam. Os resultados de resistência à compressão da matriz em diferentes idades se encontram na Figura 3-5. 


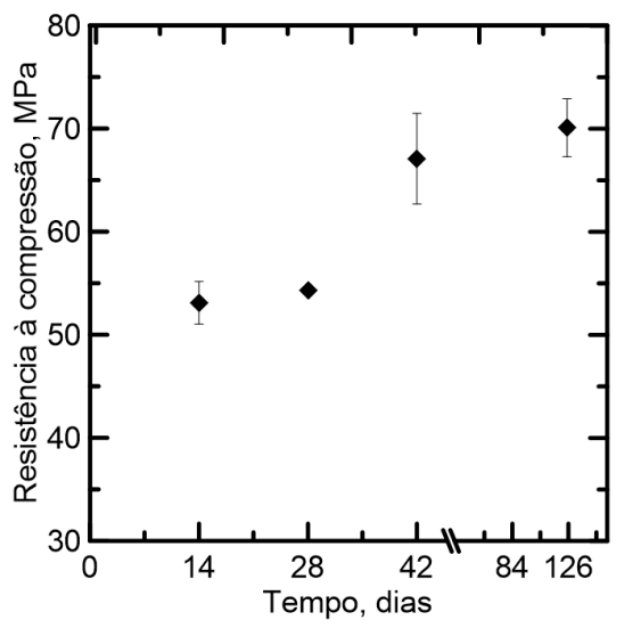

Figura 3-5 - Evolução no tempo da resistência à compressão da matriz utilizada.

A partir dos pontos mostrados na Figura 3-5 pode-se perceber que o ganho de resistência vai além dos 28 dias, sendo mais significativo entre 28 e 42 dias. Como visto no item 2.2.2, a inclusão de materiais com alto teor de aluminossilicatos leva a um consumo do hidróxido de cálcio, formando C-S-H. Como o metacaulim usado possui também alto teor de $\mathrm{Al}_{2} \mathrm{O}_{3}$, os íons de alumínio podem reagir de forma similar aos íons de silício, formando gel C-A-S-H. Essas reações secundárias que o hidróxido de cálcio sofre, dando lugar a produtos que oferecem maior resistência, podem influenciar nesse parâmetro da matriz. Uma matriz similar foi estudada por Filho et al. [65]. Neste estudo, o compósito reforçado com tecido de sisal foi ensaiado em idades diferentes, desde 28 dias a 5 anos. Houve um aumento significativo na tensão de primeira fissura, parâmetro que é relacionado principalmente às propriedades da matriz [19].

\subsection{Fibra de curauá}

As fibras de curauá usadas como reforço dos compósitos desenvolvidos neste trabalho foram extraídas das folhas da planta Ananas erectfolius, conhecida como curauá. Alguns autores já caracterizaram as propriedades mecânicas (resistência à tração, módulo de elasticidade e deformação máxima) dessa fibra e os resultados se encontram no item 2.1.2. A variação dos resultados se dá por conta de inúmeros fatores, como: condições geográficas, climáticas, variações no 
cultivo (a qualidade do solo, nível de maturação e o processo de maceração) e diferentes procedimentos de ensaio (arranjo experimental e comprimento testado).

As fibras de curauá usadas neste trabalho foram fornecidas pela CEAPAC, região de Santarém, Pará. Elas passam por um processo inicial antes de serem utilizadas para retirar impurezas e deixa-las de forma a facilitar a fabricação dos compósitos e melhorar o desempenho dos mesmos. Tal processo consistia em submergir as fibras em água quente, entre 70 e $80^{\circ} \mathrm{C}$ por uma hora e secá-las ao ar livre, sem exposição ao sol, por 48 horas. Posteriormente as fibras foram separadas em um aparato que se assemelha a um pente, com pregos (Figura 3-6). As fibras de curauá são muito finas, com seu diâmetro em torno de $50 \mu \mathrm{m}[40,43]$, e isso faz com que elas se entrelacem muito facilmente, o que justifica esse processo de separação, visando uma melhoria na aderência. A Figura 3-7 mostra as fibras antes e depois do processo.

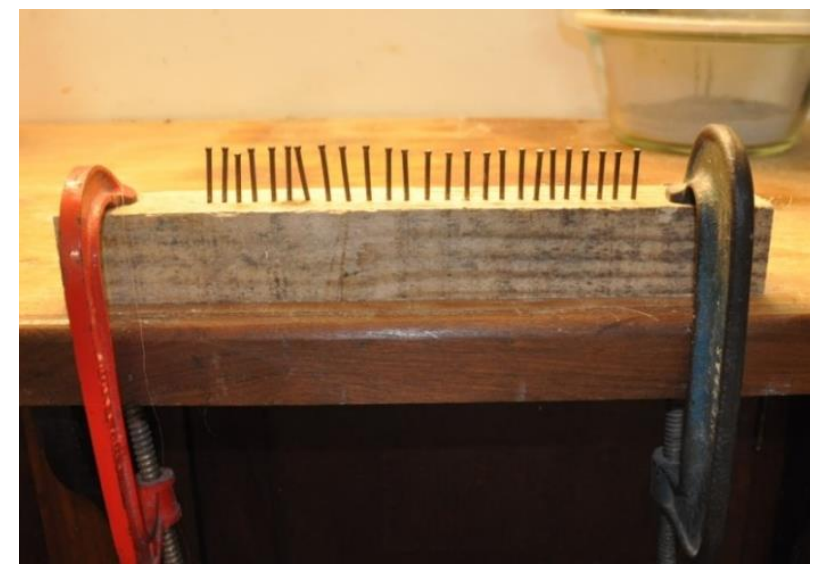

Figura 3-6 - Aparato usado para separar as fibras no processo inicial.

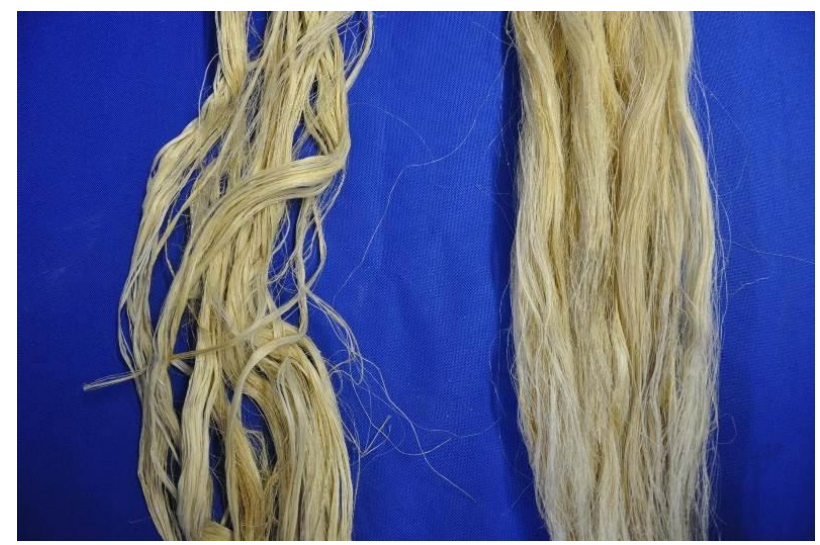

Figura 3-7 - Fibras de curauá antes (esquerda) e depois (direita) de com passarem pelo processo inicial 


\subsubsection{Microestrutura}

Para medir parâmetros como área e diâmetro do curauá, técnicas como a medição com paquímetro [42] e projeção ampliada [42,43] já foram utilizadas. Mas, como já mencionado, os filamentos das fibras de curauá são extremamente finos, tornando a medição da área dos mesmos difícil. Por isso, neste trabalho, a área transversal das fibras foi obtida por meio de análise de imagem de micrografias. Para isso, 10 amostras foram analisadas em um microscópio eletrônico de varredura (MEV), modelo Jeol JSM 6510 LV (Figura 3-8), operando de 10 a $20 \mathrm{kV}$, do Laboratório de Microscopia Eletrônica do Departamento de Engenharia de Materiais da PUC-Rio. As fibras foram previamente imersas em água por 24 horas e cortadas com lâminas de aço inoxidável de forma perpendicular ao eixo longitudinal do filamento. Fitas de carbono foram usadas para fixar as fibras no aparato do MEV.

(a)

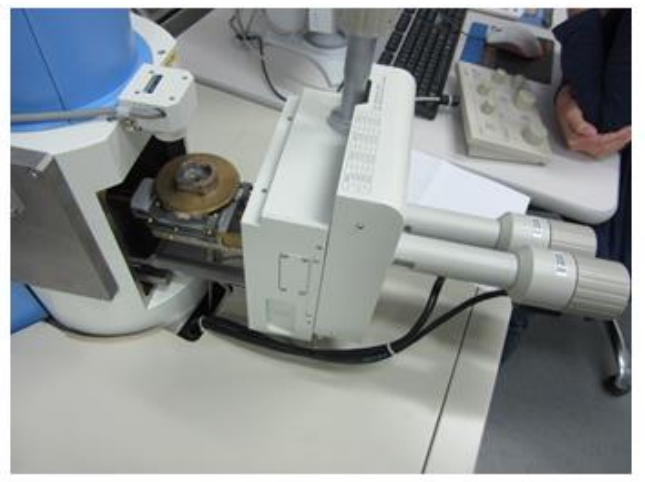

(b)

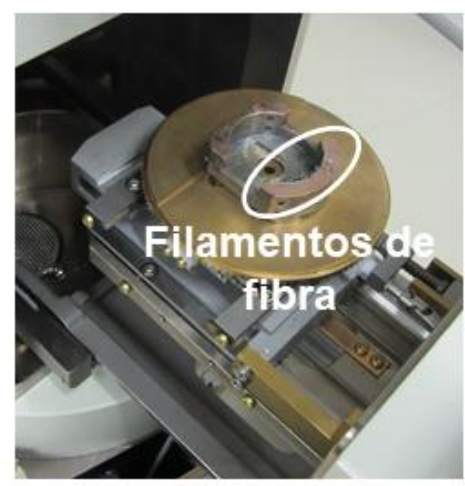

Figura 3-8 - (a) MEV utilizado e (b) detalhe das amostras de fibra de curauá.

Para tornar as fibras condutoras e adequadas à análise no MEV, as amostras foram submetidas à deposição de 30 segundos. A partir das micrografias, foi possível medir as áreas da seção transversal de cada fibra no software ImageJ com uma ferramenta de contorno do próprio software, como ilustrado na Figura 3-9. 


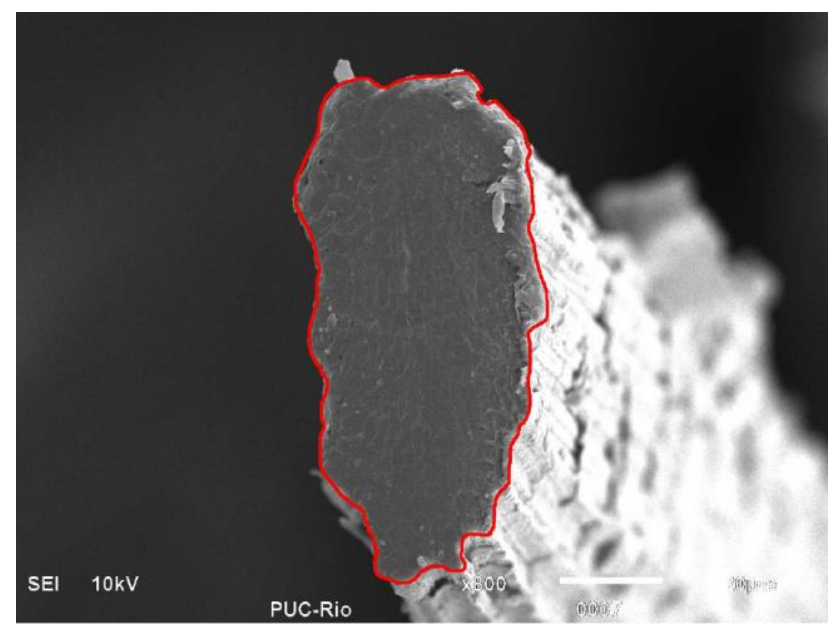

Figura 3-9 - Contorno para cálculo da área da seção transversal da fibra de curauá.

A Tabela 3-2 apresenta a área de cada amostra bem como a média e o desvio padrão. Micrografias das fibras de curauá são apresentadas na Figura 3-10. As Figuras 3-10 (b) e (c) mostram seções de diferentes amostras. A partir delas pode-se perceber que há uma grande diferença de morfologia entre as fibras, evidenciado pelo alto desvio padrão $(73 \%)$. O valor utilizado para o cálculo da resistência à tração (item 3.3.2) é aquele referente à média, 0,008 mm².

Tabela 3-2 - Área da seção transversal da fibra de curauá.

\begin{tabular}{c|c}
\hline $\begin{array}{c}\text { Seção } \\
\text { Transversal }\end{array}$ & Área $\left(\mathrm{mm}^{2} \times 10^{-3}\right)$ \\
01 & 3,73 \\
02 & 4,89 \\
03 & 3,90 \\
04 & 3,72 \\
05 & 6,10 \\
06 & 1,95 \\
07 & 5,86 \\
08 & 8,90 \\
09 & 7,39 \\
10 & 1,96 \\
Média & $8,36( \pm 6,13)$ \\
\hline
\end{tabular}

A Figura 3-10 (a) mostra a micrografia da lateral da fibra. Segundo Souza et al. [20], ela apresenta uma disposição compacta de um grande número de microfibrilas unidas por uma matriz de lignina e hemicelulose. A superfície da fibra é bem rugosa e isso pode contribuir para uma melhor aderência na matriz cimentícia. Na Figura 3-10 (d) é possível identificar parte da estrutura 
morfológica da fibra, como o lúmen, a parede secundária bem espessa e a lamela média ligando as microfibrilas.

(a)

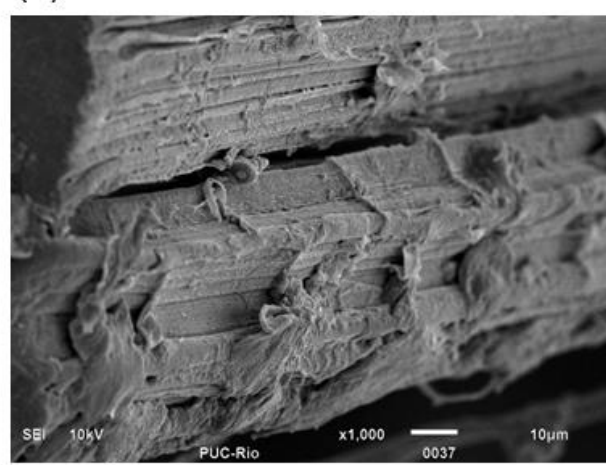

(c)

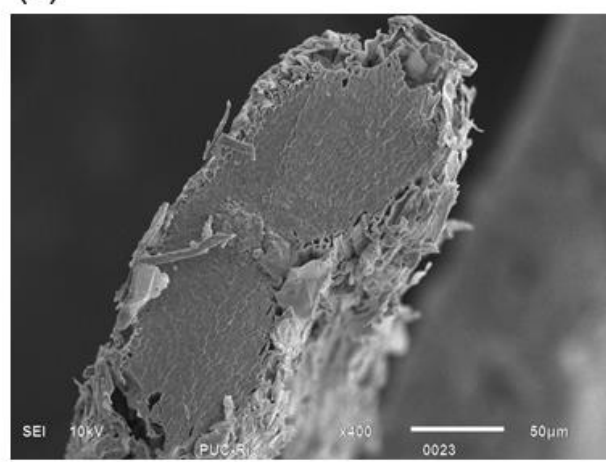

(b)

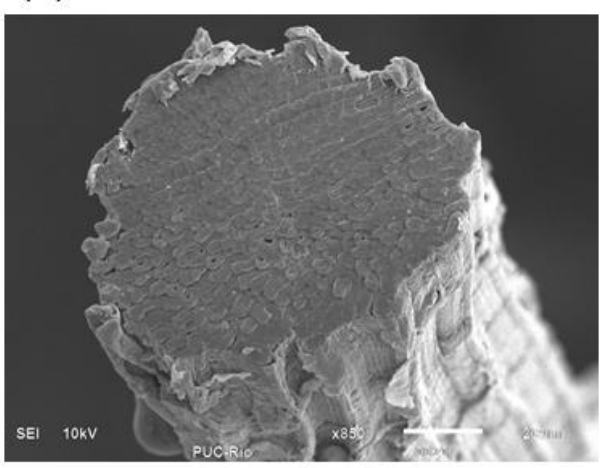

(d)

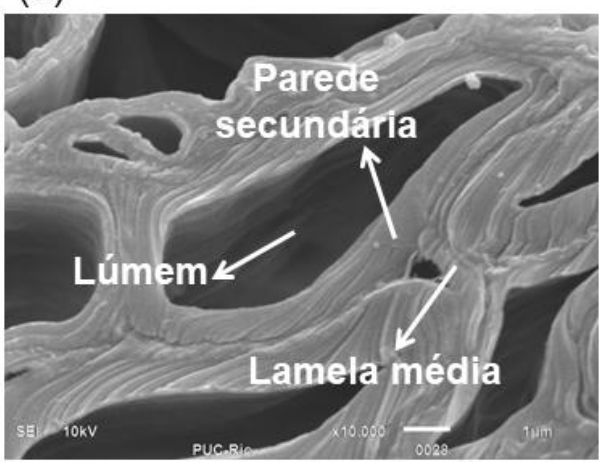

Figura 3-10 - Micrografias da fibra de curauá: (a) superfície lateral; (b) exemplo de seção transversal; (c) exemplo de seção transversal e (d) identificação de parte da estrutura morfológica.

\subsubsection{Tração}

A caracterização mecânica da fibra foi realizada por meio de ensaios de tração, segundo a norma ASTM C1557 (2014), com modificações. Foram testados 15 filamentos da fibra de curauá depois de passarem pelo processamento inicial para corresponderem às fibras utilizadas nos compósitos. Como as fibras são muito finas e flexíveis, elas necessitam de uma guia de montagem para serem presas pelas garras do arranjo experimental na máquina de ensaios mecânicos. Essas guias foram feitas de papel cartão, com densidade de 140 gramas $/ \mathrm{cm}^{2}$, e servem para evitar que o filamento seja esmagado pelas garras. Para eliminar a influência da guia, as bordas são cortadas antes do começo do ensaio. Uma ilustração da guia é mostrada na Figura 3-11. 


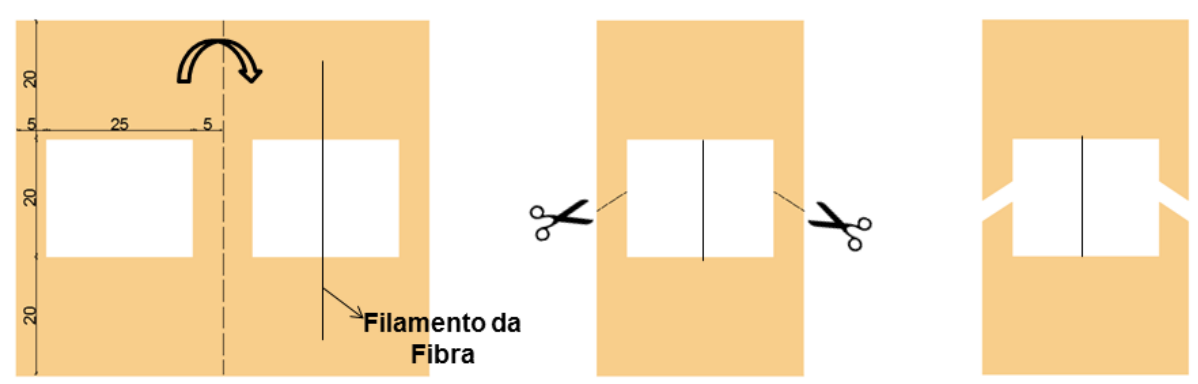

Figura 3-11 - Guia de papel cartão para ensaio de tração do filamento da fibra de curauá. O filamento é posicionado no centro da guia que é dobrada e colada com cola instantânea. Posteriormente, as laterais da guia são cortadas para não influenciarem o ensaio.

Os ensaios de tração da fibra foram realizados em uma máquina universal de ensaios mecânicos MTS 850, com capacidade de $250 \mathrm{kN}$. Como a ordem de grandeza da célula de carga na máquina é muito superior ao da previsão do ensaio, no máximo $10 \mathrm{~N}$, foi acoplada uma célula de carga de capacidade de $100 \mathrm{~N}$ ao sistema. Foram ensaiados 15 corpos de prova com velocidade de ensaio de 0,1 $\mathrm{mm} / \mathrm{min}$. Um LVDT de 7,0 $\mathrm{mm}$ foi usado para medir o deslocamento vertical e posteriormente, calcular a deformação das fibras. O deslocamento medido pelo LVDT foi comparado com o da máquina para avaliar a rigidez do sistema usado. $\mathrm{O}$ arranjo experimental completo do ensaio se encontra na Figura 3-12. As abas das guias ainda não haviam sido cortadas.
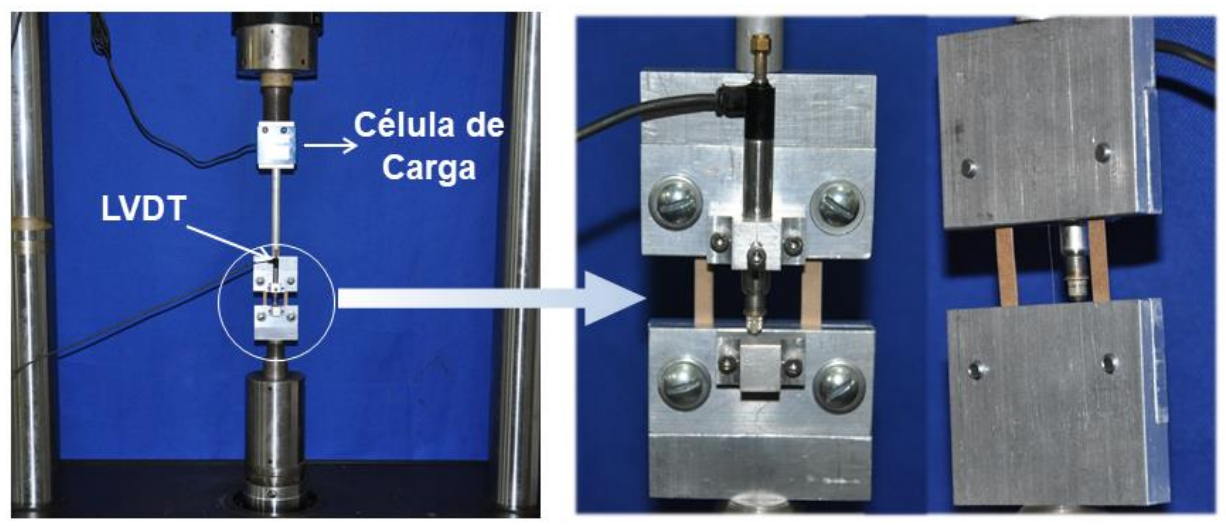

Figura 3-12 - Arranjo experimental do ensaio de tração das fibras de curauá com detalhe para as garras utilizadas.

A partir da área transversal média obtida no item 3.3.1, foi possível calcular a resistência à tração das fibras pela média aritmética das áreas das amostras. A resistência foi calculada dividindo a força pela área transversal média das fibras. 
A deformação foi calculada dividindo o deslocamento pelo comprimento livre utilizado no ensaio, de $20 \mathrm{~mm}$. A partir das curvas de resistência à tração versus deformação, foram determinados o módulo de elasticidade, a tensão máxima e a deformação máxima. O módulo de elasticidade foi calculado como o coeficiente angular da curva tensão-deformação na região correspondente ao início do ensaio. A Figura 3-13 apresenta a curva típica obtida nos ensaios. A Tabela 3-3 mostra os resultados das propriedades mecânicas com seus respectivos desvios padrão.

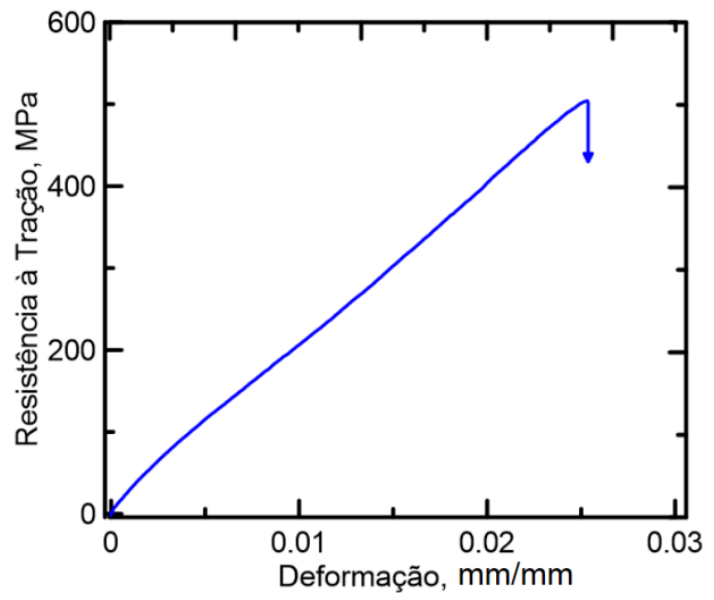

Figura 3-13 - Curva resistência versus deformação da fibra de curauá.

Tabela 3-3 - Propriedades mecânicas da fibra de curauá.

\begin{tabular}{|c|c|c|}
\hline Tensão Máxima & Módulo de Elasticidade & Deformação máxima \\
\hline $543,1 \pm 147,6 \mathrm{MPa}$ & $27,6 \pm 6,7 \mathrm{GPa}$ & $2,4 \pm 0,25 \%$ \\
\hline
\end{tabular}

A fibra de curauá, assim como a de sisal e juta, é considerada de alta performance por seus valores de tensão e módulo de elasticidade quando comparada com outras, como a de coco e piaçava [41]. Os resultados obtidos estão dentro daqueles encontrados na literatura como mostrado na Tabela 2-15 do item 2.1.2 deste trabalho.

\subsubsection{Absorção}

As fibras naturais são hidrofílicas, possuem uma estrutura porosa e, por conta disso, absorvem uma grande quantidade de água. Portanto, para determinar a absortividade das fibras, foi realizado um ensaio de absorção de água. 
Três feixes de fibra após processamento inicial, conforme descrito em 3.3, foram cortados e pesados da mesma forma que uma camada de tecido usada na fabricação dos compósitos (item 4.2.1). As amostras foram secas em estufa, previamente, a $40^{\circ} \mathrm{C}$, até a constância de massa. Os feixes foram então pesados secos e submersos em água da torneira. Leituras de massa foram feitas em 2, 4, 6, $8,10,30,60,90$ e 150 min depois de imersas. A cada leitura, as amostras eram retiradas da água, posicionadas sobre papel absorvente e cobertas com o mesmo papel durante 30 segundos. O ganho de massa se encontra na Figura 3-14.

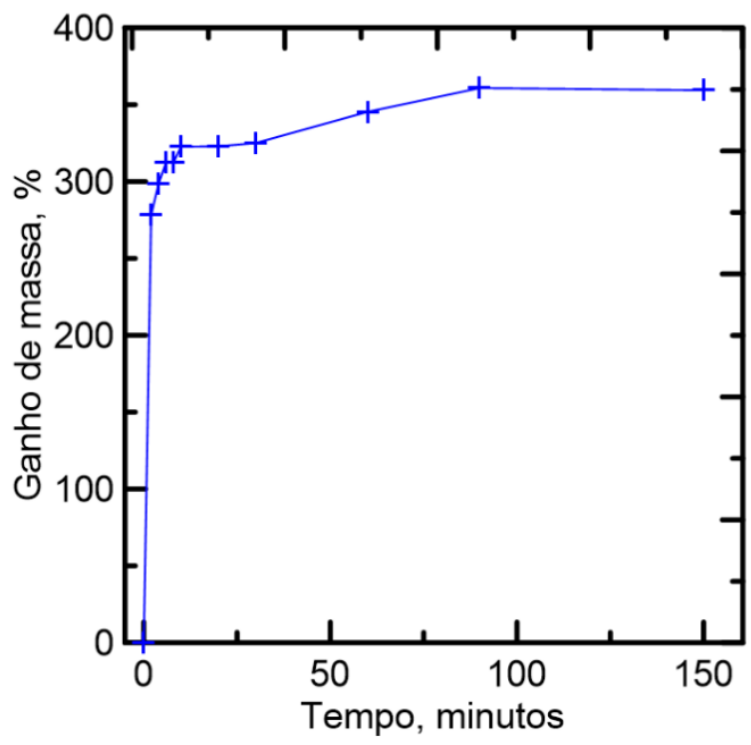

Figura 3-14 - Curva do ganho de massa do curauá ao longo do tempo.

O limite do ganho de massa é aproximadamente $360 \%$ e acontece aos 90 minutos. Esse resultado se encontra entre os valores obtido por Pimentel et al. [41], 449\% onde não há dados acerca da metodologia utilizada, e por Lopes et al. [42], 92\%, . Neste, os autores informam que após a imersão, a fibra foi brevemente seca com papel para retirar o excesso.

\subsection{Conclusões}

Neste capítulo, a matriz e a fibra usadas para fabricação dos compósitos foram caracterizadas.

Para garantir a durabilidade do compósito, metade da massa do cimento Portland foi substituída por materiais pozolânicos, metacaulim e cinza volante, conforme estudos anteriores $[41,64,65]$. Para garantir a trabalhabilidade, a matriz foi caracterizada segundo esta propriedade, por meio do ensaio de espalhamento, 
resultando em 400 mm. A resistência à compressão foi medida ao longo do tempo resultando em um breve estudo acerca da cinética de hidratação do metacaulim. Aos 28 dias, a resistência à compressão foi de 54,34 ( $\pm 0,3) \mathrm{MPa}$.

A fibra de curauá também foi caracterizada. A resistência à tração é de grande interesse por conta das solicitações que os compósitos serão submetidos. Para ter uma medida precisa da área, técnicas de análise de imagem foram usadas em imagens obtidas em microscópio eletrônico de varredura. A média da área foi de $0,008( \pm 0,006) \mathrm{mm}^{2}$ e esse valor foi o utilizado para calcular a resistência à tração. A resistência à tração foi de 543,1 $( \pm 147,6) \mathrm{MPa}$, o módulo de elasticidade obtido foi de 27,6 $( \pm 6,7)$ GPa e o alongamento máximo do filamento da fibra foi de $2,4( \pm 0,25) \%$. Os valores obtidos são compatíveis com a literatura. A absorção de água do tecido de curauá também foi medida ao longo do tempo, resultando em $360 \%$ de ganho de massa em 90 minutos. Altos valores de desvio padrão foram obtidos na caracterização da fibra, como esperado, por se tratar de um material heterogêneo. 


\section{Comportamento mecânico e mecanismos de fissuração dos compósitos cimentícios reforçados com fibra de curauá}

\subsection{Introdução}

Três tipos de compósitos foram desenvolvidos utilizando-se a matriz e fibra caracterizadas no Capítulo 3. O reforço composto pelas fibras de curauá foi da forma de tecido unidirecional: as fibras de $500 \mathrm{~mm}$ foram dispostas longitudinalmente, cada camada de tecido pesando o mesmo. Os compósitos variavam entre si no número de camadas de tecido, fração volumétrica de fibras e espessura. A fim de avaliar o comportamento mecânico dos compósitos, eles foram submetidos a ensaios de tração direta e flexão a quatro pontos. O espaçamento entre fissuras foi medido por meio de fotos tiradas das amostras no decorrer dos ensaios de tração e flexão e correlacionadas com o nível de tensão atuante. Como as amostras submetidas a flexão são solicitadas a tensões de tração e compressão, as deformações superiores e inferiores também foram medidas e um estudo do desenvolvimento da linha neutra foi realizado. Para avaliar melhor o desenvolvimento e formação das fissuras bem como o tamanho das mesmas, o método de correlação digital de imagens (DIC - Digital Image Correlation) foi utilizado para os testes de tração.

\subsection{Procedimento experimental}

\subsubsection{Fabricação dos compósitos}

Os materiais usados para a fabricação dos compósitos foram aqueles caracterizados no Capítulo 3. Cada camada de fibras longas alinhadas longitudinalmente (tecido unidirecional) media $500 \mathrm{~mm}$ e pesava 6,6 gramas. Foram fabricados três tipos de compósitos: com uma, três e cinco camadas de tecido. Os compósitos foram moldados em forma de metal, intercalando camadas de matriz com camadas de tecido, começando por uma camada de matriz, até 
chegar ao número de camadas de tecido pré-determinadas, como mostra a Figura 4-1.

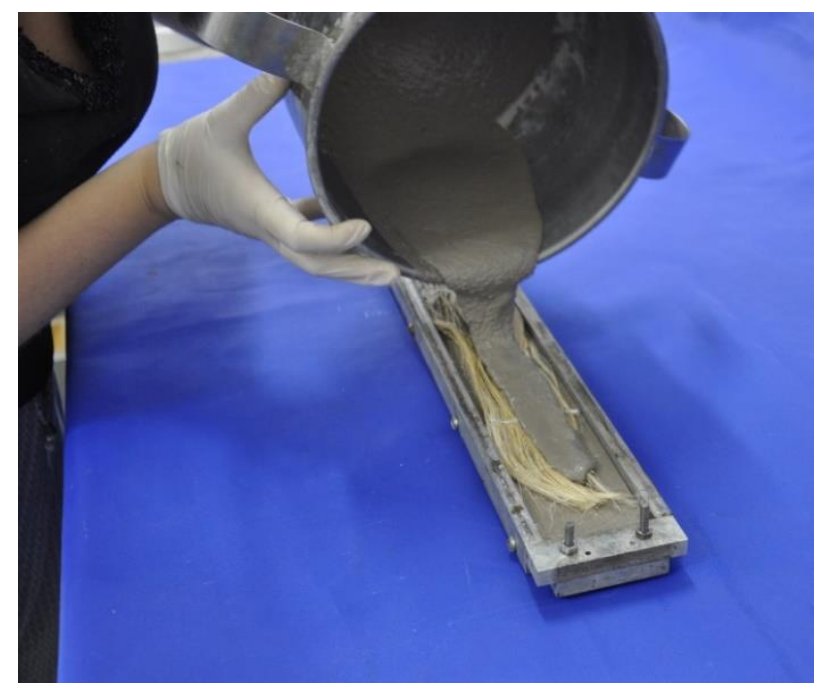

Figura 4-1 - Moldagem do compósito.

Os compósitos tinham dimensões de $500 \mathrm{~mm}$ de comprimento por $60 \mathrm{~mm}$ de largura e espessura variando com a quantidade de camadas: $6,0 \mathrm{~mm}, 10,5 \mathrm{~mm}$ e 13,5 mm para os compósitos de 1, 3 e 5 camadas, respectivamente. Como a espessura variou entre as amostras, para cada corpo de prova foi feita uma média entre três medidas de espessura. Essa média é apresentada na respectiva seção de cada ensaio. A variação do número de camadas de tecido gerou compósitos com diferentes frações volumétricas de fibra: 4,0 \%, 7,5\% e 8,5\%, do menor número de camadas para o maior. Essa fração foi calculada por meio dos pesos das fibras, com densidade aparente de 0,9 grmas $/ \mathrm{cm}^{3}$, e dos materiais da matriz, resultando em 2,75 gramas $/ \mathrm{cm}^{3}$. A Figura 4-2 mostra um exemplo de espessura de cada tipo de compósito.

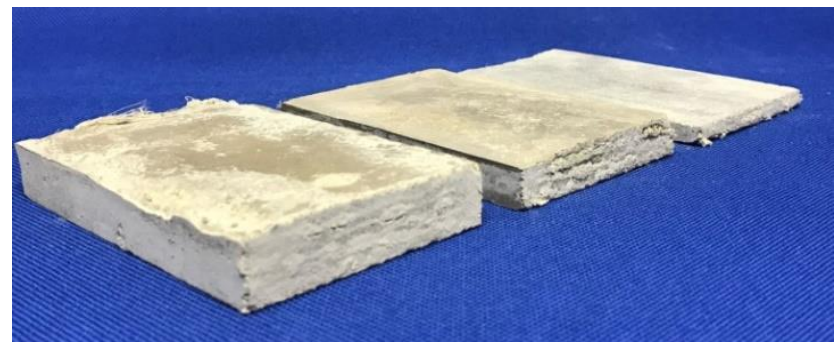

Figura 4-2 - Diferença entre as espessuras dos três compósitos.

Após a moldagem, as amostras ficaram em seus moldes cobertas por plástico filme com uma fina película de água durante 72 horas antes de serem desmoldadas e curadas em água. As amostras demoravam a ganhar resistência 
inicial suficiente para o desmolde usual de 24 horas. A demora no ganho da resistência inicial pode ser devido à hemicelulose presente nas fibras, que desacelera o processo de pega $[68,69]$. As amostras também apresentaram problemas de fissuração por retração, principalmente as de espessura menor, bem como dificuldades no desmolde (algumas fibras agarravam na forma na parte inferior) e foram descartadas. Esses problemas foram remediados com o uso do plástico filme logo após a moldagem e com o uso de papel do tipo "contact" forrando toda a forma.

Ao todo foram ensaiados 33 corpos de prova para os resultados deste Capítulo: 13 de uma camada, 10 de três camadas e 10 de cinco camadas, sendo três corpos de prova para os ensaios de flexão e sete para os de tração.

\subsubsection{Ensaios}

A fim de estudar o comportamento mecânico e analisar os mecanismos de formação de fissuras dos compósitos desenvolvidos, dois ensaios foram realizados: tração direta e flexão a quatro pontos.

\subsubsection{Tração}

Testes de tração direta foram realizados em uma máquina MTS, modelo 311.11 com capacidade de $1000 \mathrm{kN}$, com garras hidráulicas em forma de cunhas, a uma taxa de deslocamento do atuador de $0,1 \mathrm{~mm} / \mathrm{min}$.. As amostras tinham dimensões de $500 \mathrm{~mm}$ x $60 \mathrm{~mm}$ x $(5,5 ; 10,5 ; 14) \mathrm{mm}$ (comprimento x largura $\mathrm{x}$ média da espessura por tipo de compósito) e foram ensaiadas aos 28 dias de idade. As amostras foram retiradas da condição de cura um dia antes dos ensaios. Placas de aço foram presas nas extremidades das amostras com parafusos, e o conjunto foi preso na máquina, resultando em condição bi engastada do ensaio. Para cada amostra foi utilizado um torque diferente, com o auxílio de um torquímetro, como mostrado na Tabela 4.1.

Tabela 4-1 - Torque aplicado nas placas de aço.

\begin{tabular}{c|c}
\hline Tipo de compósito & Torque aplicado $(N \times \mathrm{mm})$ \\
\hline camada & 7 \\
3 camadas & 8,5 \\
5 camadas & 15,8 \\
\hline
\end{tabular}


Para medir o deslocamento vertical, dois LVDTs foram posicionados nas laterais das amostras, com comprimento livre de $190 \mathrm{~mm}$. O deslocamento adotado para posterior cálculo da deformação foi a média das leituras dos LVDTs. A Figura 4-3 mostra o arranjo experimental do ensaio.

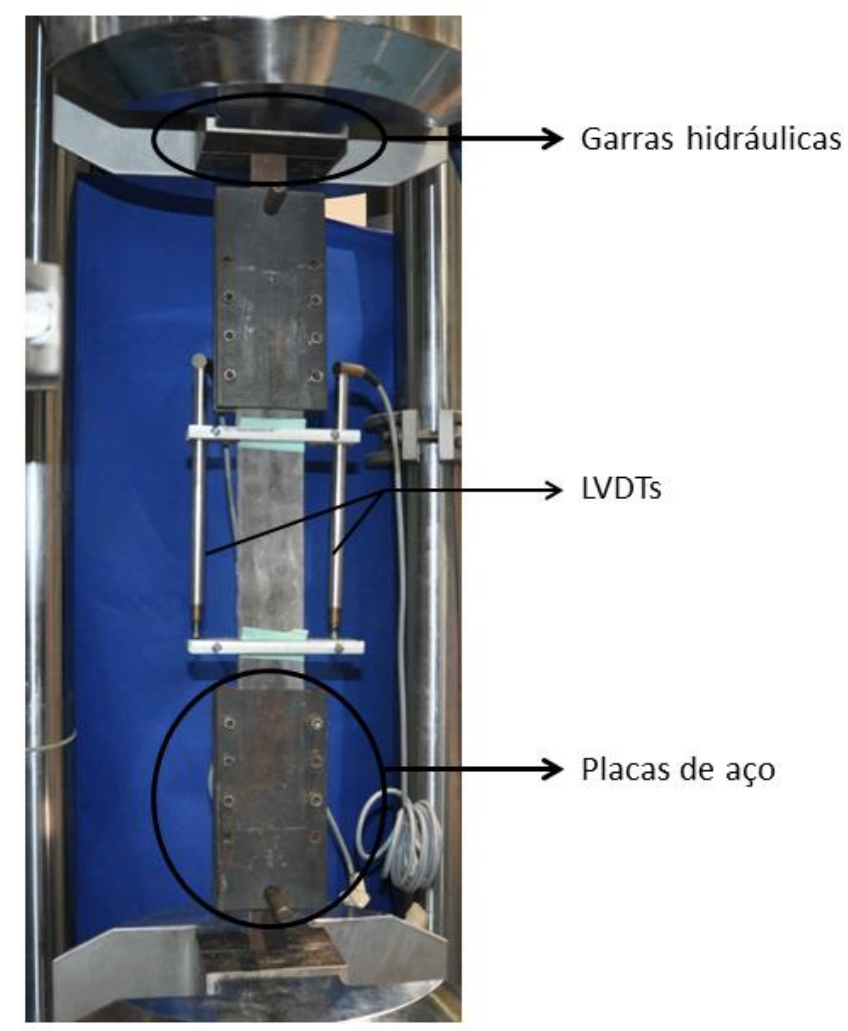

Figura 4-3 - Arranjo experimental usado para ensaios de tração.

A fim de acompanhar o desenvolvimento das fissuras ao longo do ensaio, uma câmera digital, modelo Nikon D90, foi posicionada diretamente para o arranjo. Utilizando o software Camera ControlPro2, imagens do corpo de prova foram tiradas a cada 10 segundos com resolução de 4200 x 2690 pixels. Para medir o espaçamento, as fotos de cada ensaio foram analisadas e aquelas que apresentaram novas fissuras aparentes foram separadas. De posse dessas fotos, o software ImageJ foi utilizado para medir o espaçamento entre as fissuras de cada foto. Cada foto representa um momento do ensaio assim, cada valor de espaçamento foi correlacionado com um ponto na curva de tensão versus deformação. Esse procedimento auxiliou na identificação das Zonas que representam estágios de carregamento.

Além das fotos, outro método utilizado para acompanhar mais precisamente a formação de fissuras além de medir o tamanho das mesmas foi a correlação 
digital de imagens (DIC). Uma amostra de cada tipo de compósito foi testada à tração direta utilizando o DIC.

O DIC é uma técnica que não tem contato com o corpo de prova, de alta sensibilidade que mede campos completos de deslocamentos. Essa técnica foi desenvolvida por Sutton et al. e ganha espaço enquanto novas lentes e softwares foram evoluindo. Primeiramente, deve-se selecionar uma área de interesse que será dividida em grids virtuais igualmente espaçados. Os deslocamentos são computados em cada ponto do grid. Definem-se então os subsets (subconjunto de pixels) e os steps (a distância em pixels que um subset se encontra do outro) [111,112]. Então, rastreia-se o movimento do ponto central do subset da imagem de referência (antes da deformação) e das imagens deformadas, como mostra a Figura 4-4.

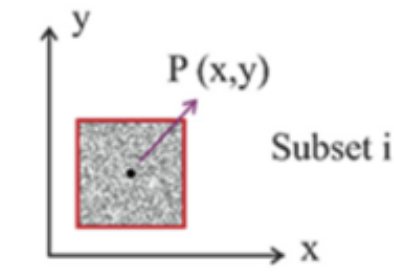

Imagem de referência

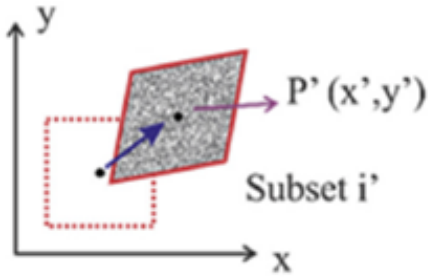

Imagem deformada

Figura 4-4 - Esquema de um subset de referência com a correlação do mesmo em uma imagem deformada.

Para fazer a correspondência entre os deslocamentos do centro de cada subset com todos os pontos discretizados é necessário um algoritmo de correlação. O algoritmo utilizado foi o algoritmo de diferenças quadradas (NSD - normalized squared diferences). Ainda, para suavizar os pontos entre os subsets, a fim de ter uma representação contínua, interpolam-se os pontos.

Para garantir a singularidade de cada subset é necessário ter uma superfície que apresente um padrão aleatório de alto contraste. Para garantir isto, as superfícies das amostras foram pintadas com tinta branca fosca com respingos de tinta preta fosca. As cores foscas são usadas para não gerar variações na iluminação. Fontes de luz são usadas também para garantir iluminação sem variações (Figura 4-5). A Figura 4-6 mostra a caracterização de uma amostra. 


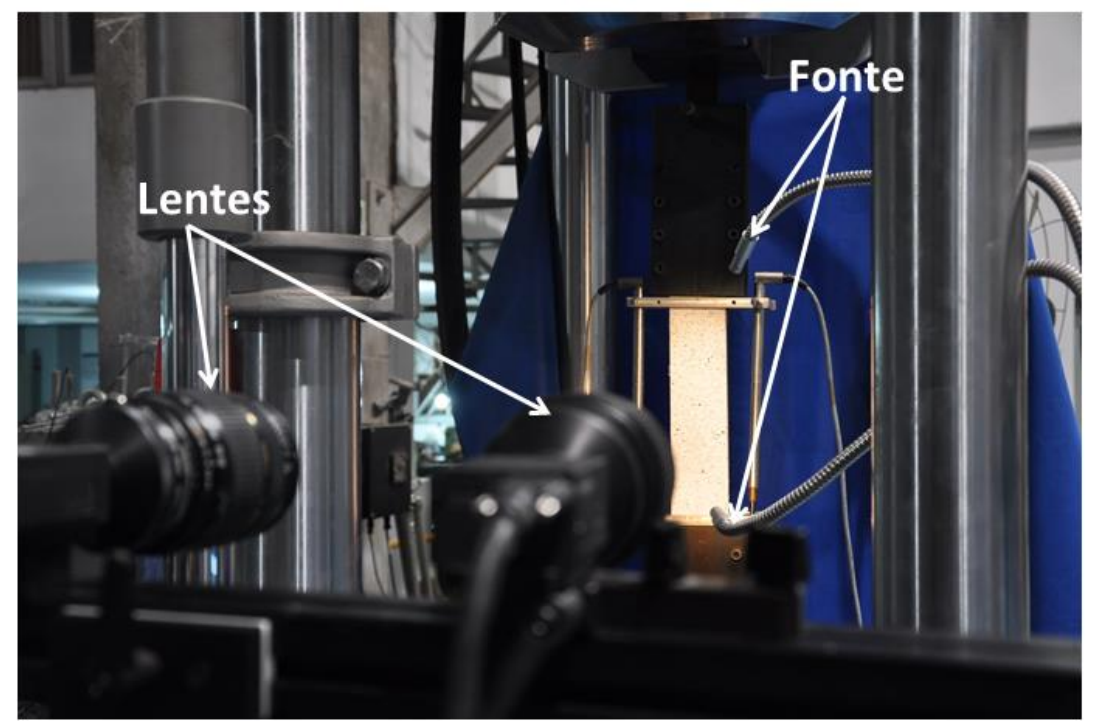

Figura 4-5 - Arranjo experimental utilizado para o DIC.

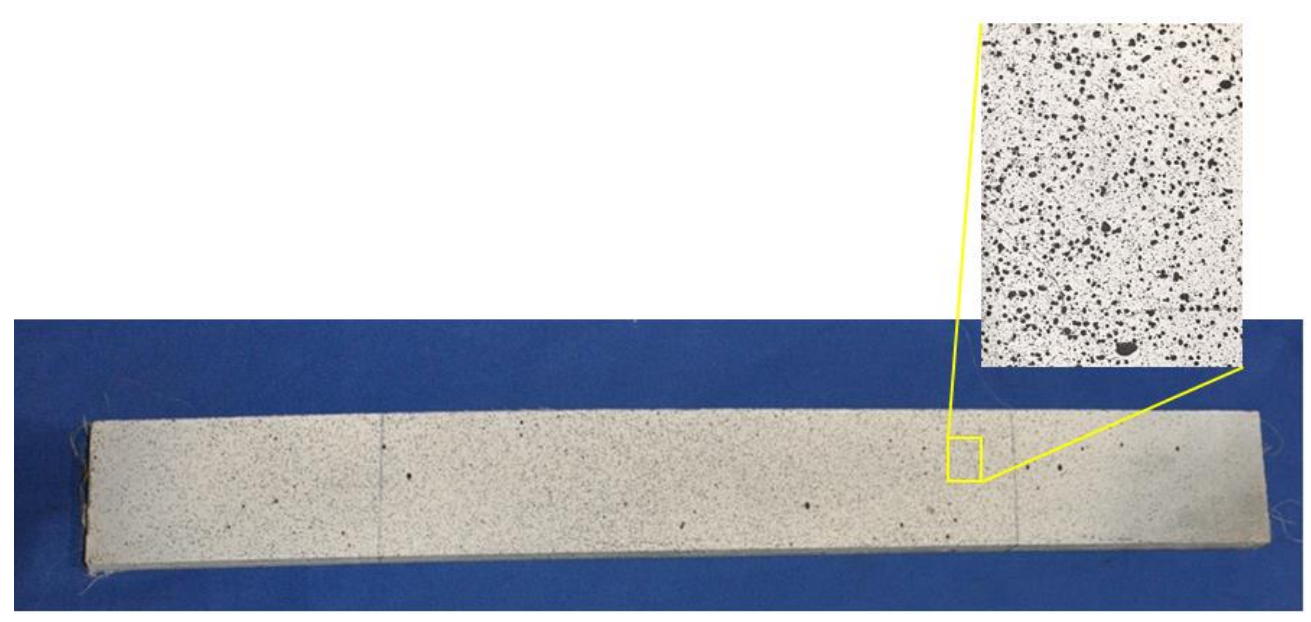

Figura 4-6 - Amostra caracterizada com fundo branco fosco, com pontos preto fosco.

O sistema estereoscópico foi composto de duas câmeras do tipo CCD de 5MP (Point Grey GRAS-50S5M) com resolução de 2448x2048 pixels com lentes de alta resolução do tipo Tamron A031 (AF28-200mm F/3.8-5.6). Esse sistema caracteriza a triangulação necessária para se ter uma medição em três dimensões. O software para aquisição e de processamento de imagens empregados foram o VIC SNAP e o VIC-3D 2010, ambos da Correlated Solutions Inc. O campo analisado foi dividido em subsets de 29 pixels com steps de 7 pixels. A área de interesse (Figura 4-7) incluía $200 \mathrm{~mm}$ do corpo de prova e é referenciada no item 4.3 como o intervalo $(-100,+100)$. 


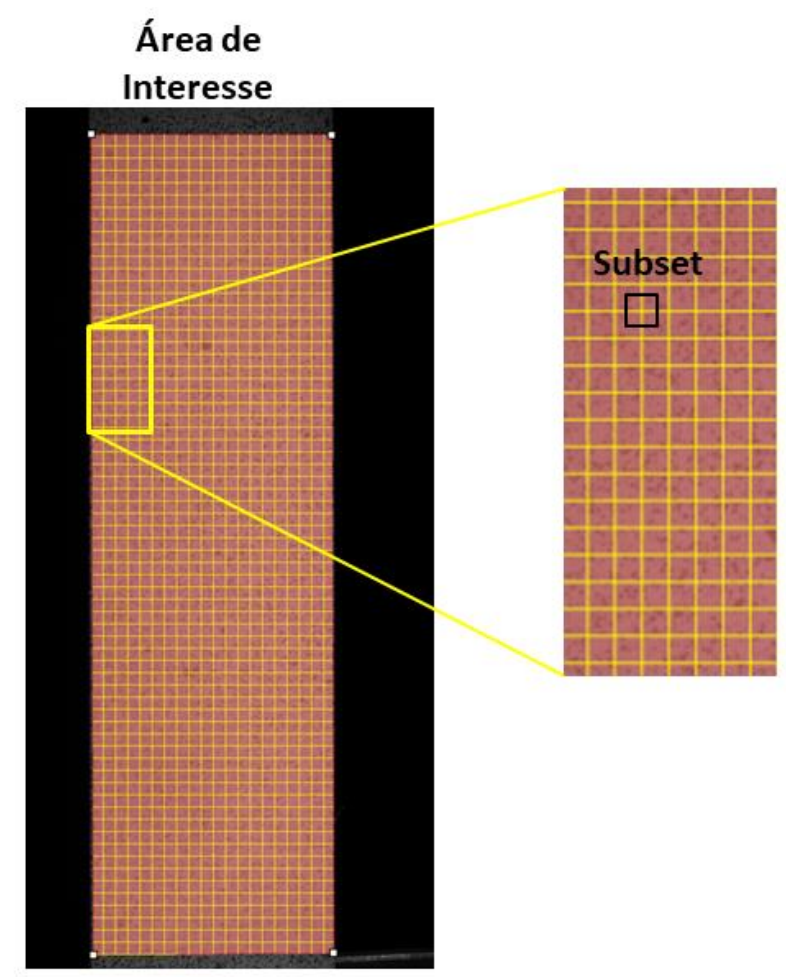

Figura 4-7 - Demarcação da área de interesse com detalhe do subset.

A fim de analisar a formação de fissuras a partir dos valores de deformação, foram plotados gráficos com os valores de deformação versus posição do eixo axial para diferentes momentos do ensaio. Para fazer uma estimativa da média da abertura das fissuras para diferentes momentos do ensaio, foi utilizado o seguinte protocolo:

i.Escolha do momento de interesse do ensaio;

ii. Plotagem do gráfico de deformação versus posição axial do momento escolhido;

iii. Identificação visual da quantidade de fissuras em uma dada região na foto tirada no momento escolhido;

iv. Multiplica-se o valor de deformação pelo o comprimento da região analisada e divide-se esse resultado pelo número de fissuras identificadas.

O resultado é referente ao valor médio aproximado do tamanho da abertura das fissuras identificadas na região. Esse valor é dito aproximado por conta das limitações do método. Por exemplo, a resolução do DIC reconhece valores de deformação somente acima de 60 microstrains e há limitações também para 
identificar o número de fissuras pelas fotos por conta das mesmas serem estreitas (menores que $10 \mu \mathrm{m}$ no início da formação).

\subsubsection{Flexão}

Testes de flexão a quatro pontos foram realizados em uma máquina MTS, modelo 810 com capacidade de 500 kN. De forma similar ao ensaio de tração nas fibras (item 3.3.1), para uma aquisição mais precisa de dados, células de carga foram acopladas ao sistema: uma de $1 \mathrm{kN}$ para os compósitos de uma camada e uma de $10 \mathrm{kN}$ para os compósitos de três e cinco camadas. Para se adequarem ao arranjo experimental disponível, as bordas das placas foram serradas um dia antes dos ensaios. Como a superfície superior das placas não era completamente uniforme, colocou-se uma camada de massa plástica na região onde os roletes superiores iam aplicar a carga. Assim, as dimensões finais das amostras para este ensaio foram $320 \mathrm{~mm}$ x $60 \mathrm{~mm}$ x $(6,3 ; 11,0 ; 14,5) \mathrm{mm}$ (comprimento x largura $\mathrm{x}$ média da espessura para cada tipo de compósito). Os ensaios foram realizados com controle de deslocamento a uma taxa de 2,0 $\mathrm{mm} / \mathrm{min}$ aos 28 dias de idade das amostras. A fim de medir as deformações de tração e compressão, dois strain gages foram colados na parte superior central e inferior central da amostra. O deslocamento vertical foi medido por dois LVDTs posicionados no meio da amostra, um de cada lado da amostra, como ilustra a Figura 4-8. Os dados obtidos pelos strain gages também foram usados para fazer uma análise do desenvolvimento da profundidade da linha neutra. 


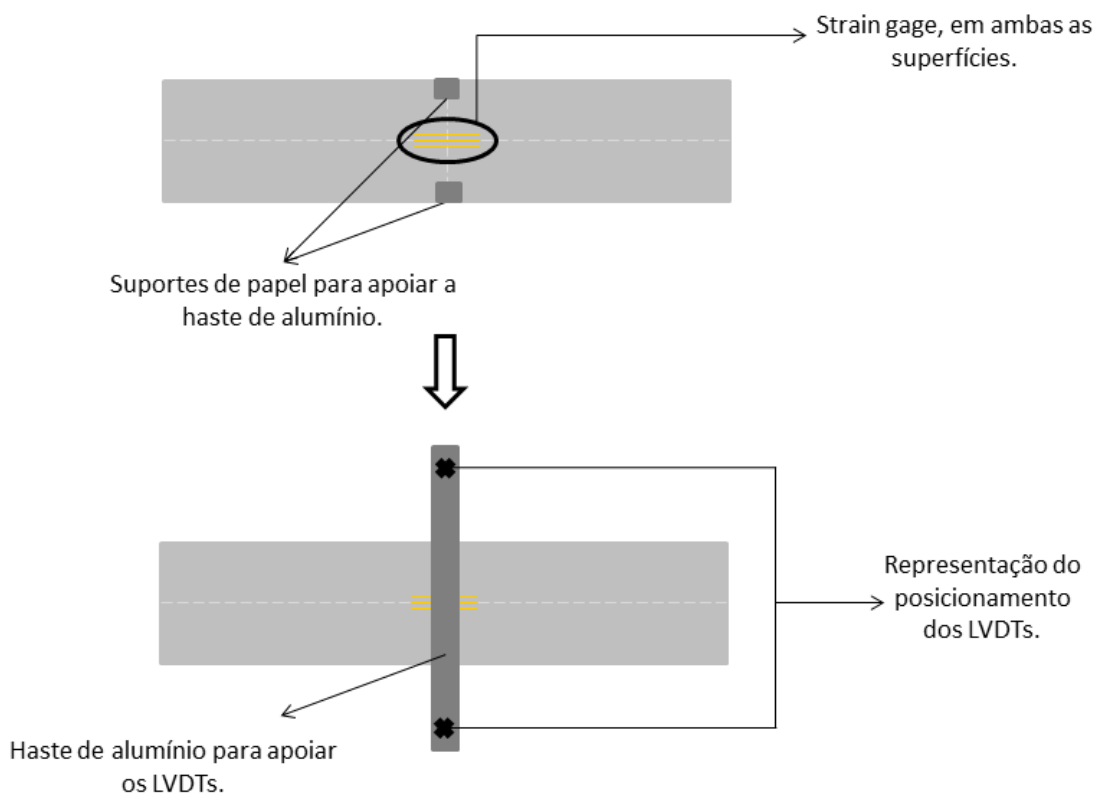

Figura 4-8 - Posicionamento dos strain gages e suporte para os LVDTs.

Do mesmo modo que o ensaio de tração direta, a formação de fissuras foi monitorada no ensaio de flexão, usando a mesma câmera e software, como descrito em 4.2.2.1. A diferença é que um espelho foi posicionado abaixo da amostra para conseguir ângulo suficiente para as fotos. $\mathrm{O}$ arranjo experimental do ensaio de flexão é mostrado na Figura 4-9.

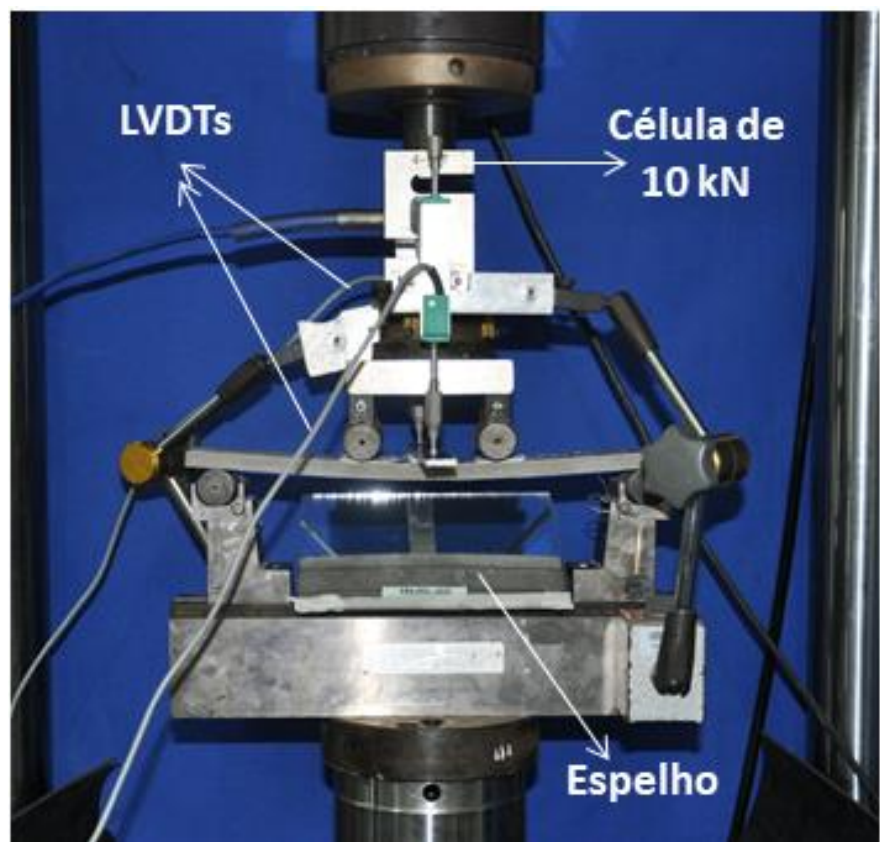

Figura 4-9 - Arranjo experimental usado em ensaios de flexão a quatro pontos. Célula usada para amostras de 3 e 5 camadas. 


\subsection{Resultados e Discussões}

As curvas apresentadas nesta seção correspondem àquelas consideradas de comportamento típico. Os mecanismos de fissuração dos compósitos quando submetidos aos ensaios de tração direta e flexão a quatro pontos são discutidos, bem como o desenvolvimento da linha neutra no ensaio de flexão. Os valores notáveis, como resistência e tenacidade, dentre outros apresentados, são a média aritmética das amostras ensaiadas. Os respectivos desvios padrão são apresentados.

\subsubsection{Comportamento dos compósitos submetidos à tração direta e seus mecanismos de fissuração}

Para um melhor entendimento dos mecanismos de fissuração e formação de fissuras, a Figura 4-10 apresenta o comportamento à tração do compósito reforçado com três camadas de tecido unidirecional de curauá. Quatro zonas principais são identificadas com números romanos. A primeira zona, Zona I, é onde matriz e reforço se comportam linearmente, é a zona linear elástica e ela é governada principalmente pelas características da matriz uma vez que o reforço representa menos que $10 \%$ do compósito em volume [19]. O "bend over point" (BOP) corresponde ao começo da fissuração da matriz. O início da primeira fissura é chamado de BOP- e quando a fissura é completamente formada, $\mathrm{BOP}+$. Observa-se que para os compósitos com uma e três camadas, o espaço entre BOPe BOP+ é praticamente imperceptível e eles perdem parte da rigidez inicial aos 3,5 MPa. Enquanto que para os compósitos com cinco camadas, o alcance do BOP vai até $6 \mathrm{MPa}$. 


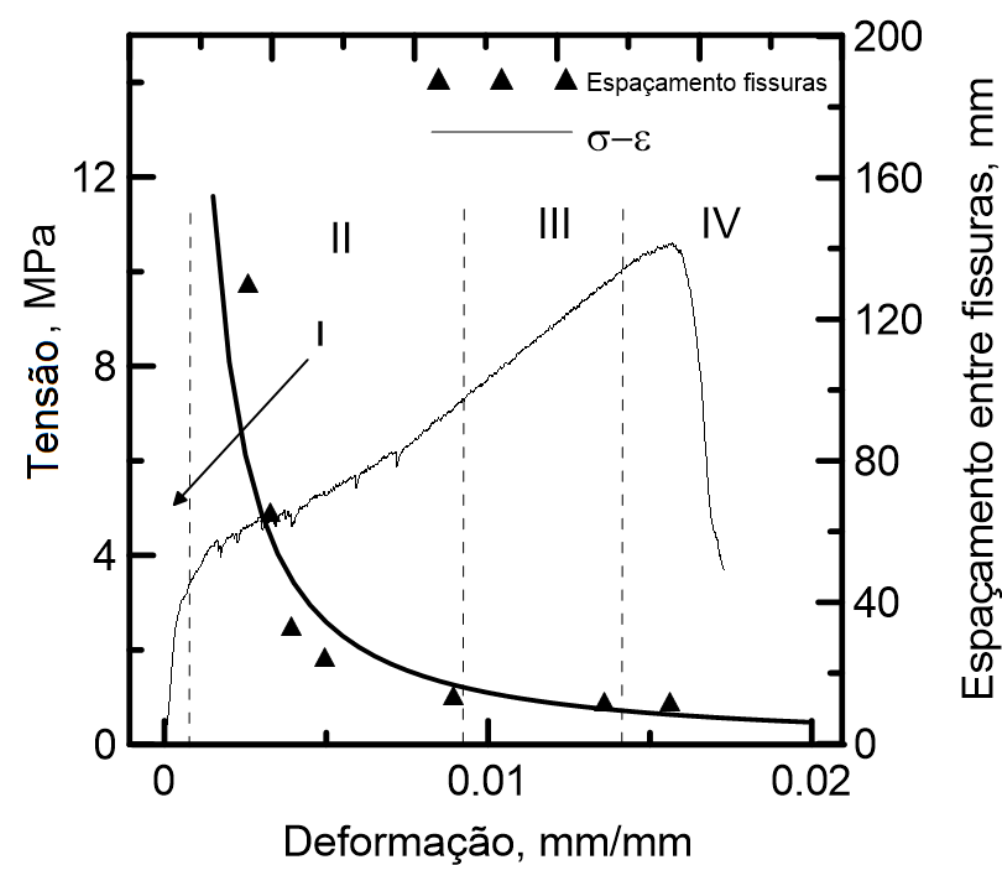

Figura 4-10 - Zonas que representam os estágios de carregamento do compósito de três camadas submetido à tração direta.

Após o BOP, há a formação de mais fissuras na Zona II onde a rigidez sofre um grande decréscimo. $\mathrm{O}$ espaço entre fissuras diminui enquanto mais fissuras são formadas. Por exemplo, para o compósito de três camadas, o espaço entre as fissuras cai de $130 \mathrm{~mm}$ para 12,7 $\mathrm{mm}$ ao longo da Zona II. Percebemos que a rigidez do sistema desenvolvido é alta o bastante para manter as fissuras bem estreitas, até a saturação do espaço entre elas, o que acontece aos 1360 microstrains. Nesta Zona, a rigidez depende do volume de fibras, suas características e de atributos da aderência entre fibra-matriz [113].

Quando o compósito atinge a saturação do espaçamento entre fissuras, por volta de 11,5 mm de deformação, as fissuras existentes começam a abrir: na Zona III nenhuma nova fissura é formada, tem-se apenas o aumento das fissuras já existentes. Assim, a Zona III é regida principalmente pelas características do tecido [9,114], causando aumento na rigidez no compósito. A Zona III termina quando uma fissura é localizada. Na Zona IV a fissura localizada abre até o compósito chegar ao comportamento de strain softening, marcando a ruptura do compósito. A Figura 4-11 mostra a resposta dos três compósitos testados sob tração direta. Todos os compósitos apresentaram comportamento strain hardening [19]. 


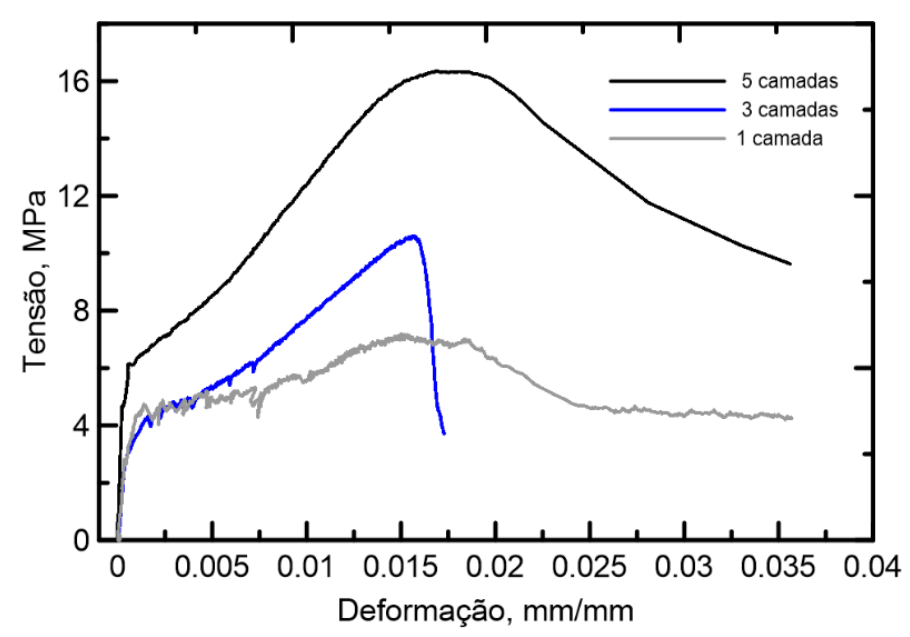

Figura 4-11 - Resposta dos três diferentes de compósitos à tração direta.

É possível observar que, à medida que a fração volumétrica de fibra (número de camadas) aumenta, a rigidez pós-fissuração também aumenta. Uma reta foi aproximada das Zonas II e III (Figura 4-12 (a)) para comparar a rigidez, calculada como sendo o coeficiente angular das retas, entre os tipos de compósitos. Os resultados se encontram na Figura 4-12 (b).

(a)

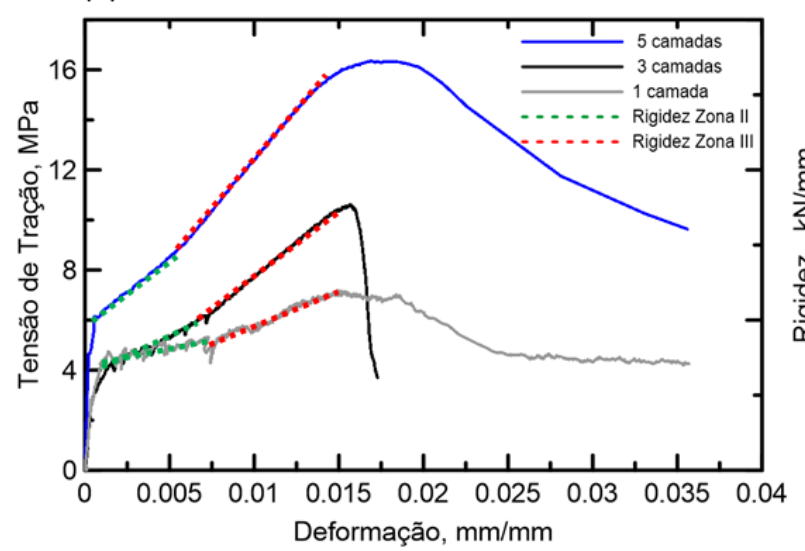

(b)

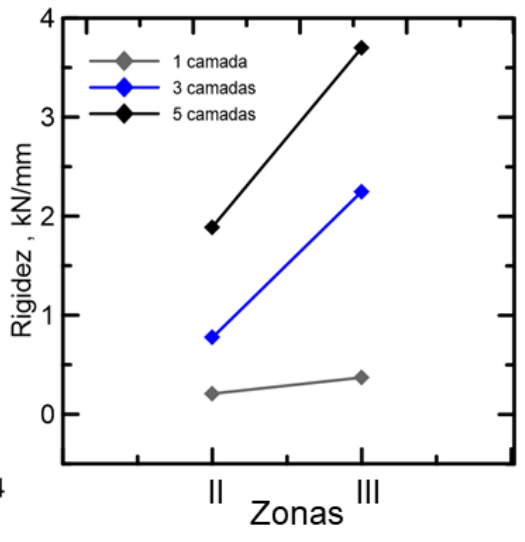

Figura 4-12 - (a) Reta aproximada para cálculo da rigidez; e (b) valores da rigidez por Zona, II e III, para os três tipos de compósitos.

A Figura 4-13 mostra o espaçamento entre fissuras medido ao longo do ensaio por meio de fotos para cada compósito. 


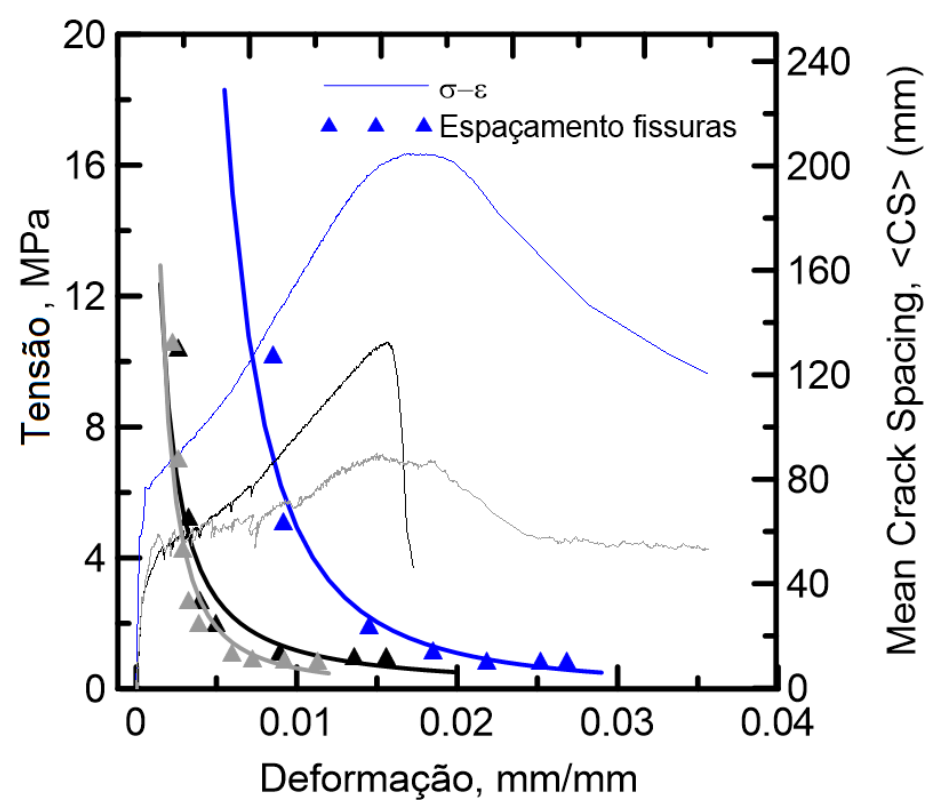

Figura 4-13 - Compósitos submetidos à tração e seus respectivos espaçamentos entre fissuras.

Cabe ressaltar, que as fissuras observadas são de abertura muito pequena, como discutido mais adiante. Esse fato pode ter influenciado na visualização das fissuras pelas imagens das fotos tiradas. Por exemplo, dada uma fissura bem pequena, no momento da sua formação, ela pode não ter sido notada. Porém, chegando na Zona III essa fissura aumenta de tamanho, se tornando visível só neste momento e então contabilizada. Exemplo disto é observado para o compósito de 5 camadas que ao final do ensaio o espaçamento entre as fissuras ainda não tinha se estabilizado completamente (marcadores azuis da curva na Figura 4-13). Por fim, pode ter ocorrido a formação de fissuras que não estavam no campo de alcance da foto. Para o ensaio de tração, fissuras se formaram na região compreendida pelas garras e na outra face da amostra que a câmera não atingia.

Apesar dos limites de resistências de cada tipo de compósito variarem entre si, a deformação final correspondente permaneceu entre 1,2\% e 1,6\% para os três tipos, como resumido na Tabela 4-2. 
Tabela 4-2 - Resumo dos valores das propriedades mecânicas para os três compósitos desenvolvidos

\begin{tabular}{c|c|c|c}
\hline Compósito & $\begin{array}{c}\text { Resistência } \\
(M P a)\end{array}$ & $\begin{array}{c}\text { Deformação máxima } \\
(\%)\end{array}$ & Tenacidade $(J)$ \\
1 camada & $\begin{array}{c}6,3 \pm 0,8 \\
(12 \%)\end{array}$ & $1,2 \pm 0,4(33 \%)$ & $7,9 \pm 2,7(34,2 \%)$ \\
3 camadas & $\begin{array}{c}9,7 \pm 1,4 \\
(14 \%)\end{array}$ & $1,4 \pm 0,1(10 \%)$ & $13,7 \pm 1,5(10,8 \%)$ \\
5 camadas & $\begin{array}{c}14,7 \pm 1,2 \\
(8 \%)\end{array}$ & $1,6 \pm 0,2(25 \%)$ & $28,4 \pm 2,4(8,5 \%)$ \\
\hline
\end{tabular}

Pode-se notar, pelos desvios padrões apresentados, que o compósito com comportamento com menos variações foi o de 3 camadas.

Na Tabela 4-3, tem-se a quantidade de fissuras, seu tamanho médio e o espaçamento entre as fissuras para cada corpo de prova submetido ao ensaio com DIC. Nesta tabela, os valores são referentes àqueles ao fim do ensaio com as amostras observadas ao estereoscópico, portanto sem carga atuante.

Tabela 4-3 - Quantidade de fissuras, tamanho médio e espaçamento entre elas após o término do ensaio de tração.

\begin{tabular}{c|c|c|c}
\hline Compósito & $N^{o}$ de fissuras & Tamanho Médio $(\mu \mathrm{m})$ & Espaçamento $(\mathrm{mm})$ \\
\hline 1 camada & 12 & 42,2 & 21,5 \\
3 camadas & 17 & 39,4 & 13,9 \\
5 camadas & 56 & 17,8 & 4,2 \\
\hline
\end{tabular}

Os campos de deformações longitudinais $\left(\varepsilon_{y y}\right)$ gerados pelo DIC dos compósitos reforçados com 1, 3 e 5 camadas são mostrados na Figura 4-14. A escala da deformação se encontra ao lado das amostras, onde a cor vermelha representa valores altos, maiores que $1,75 \%$, e a cor roxa representa os níveis mais baixos, até $0,25 \%$. 
(a)

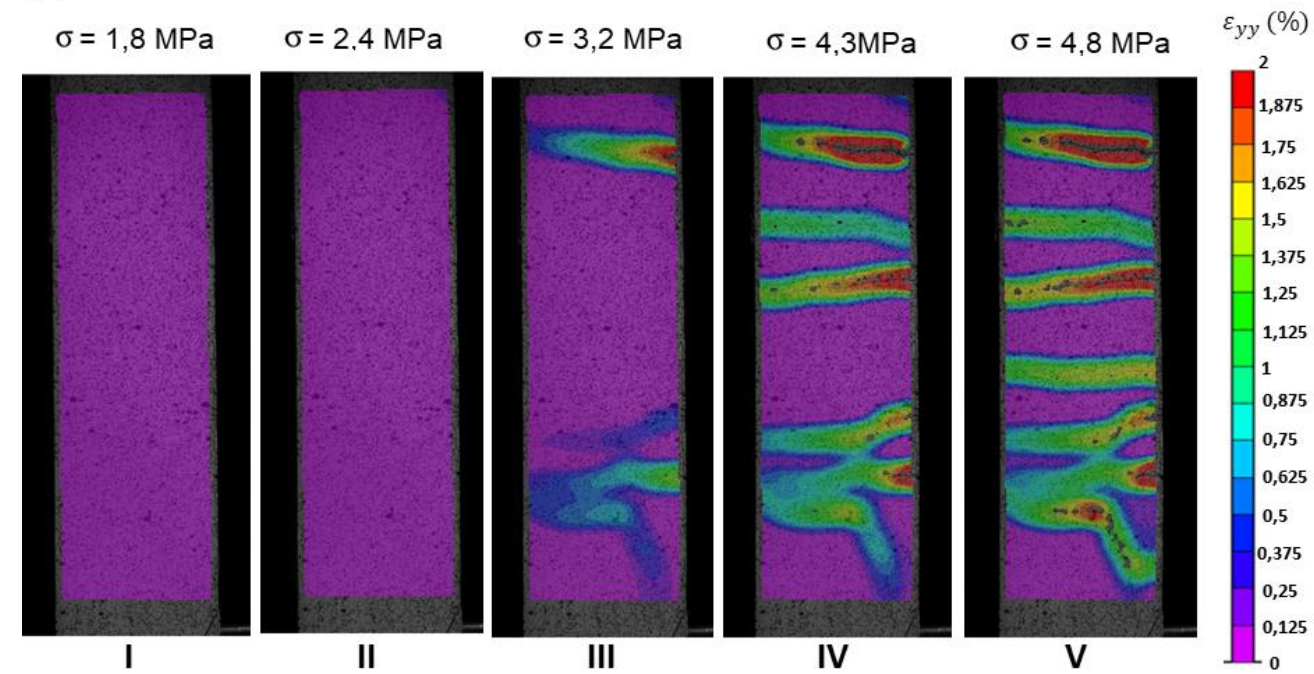

(b)

3 camadas

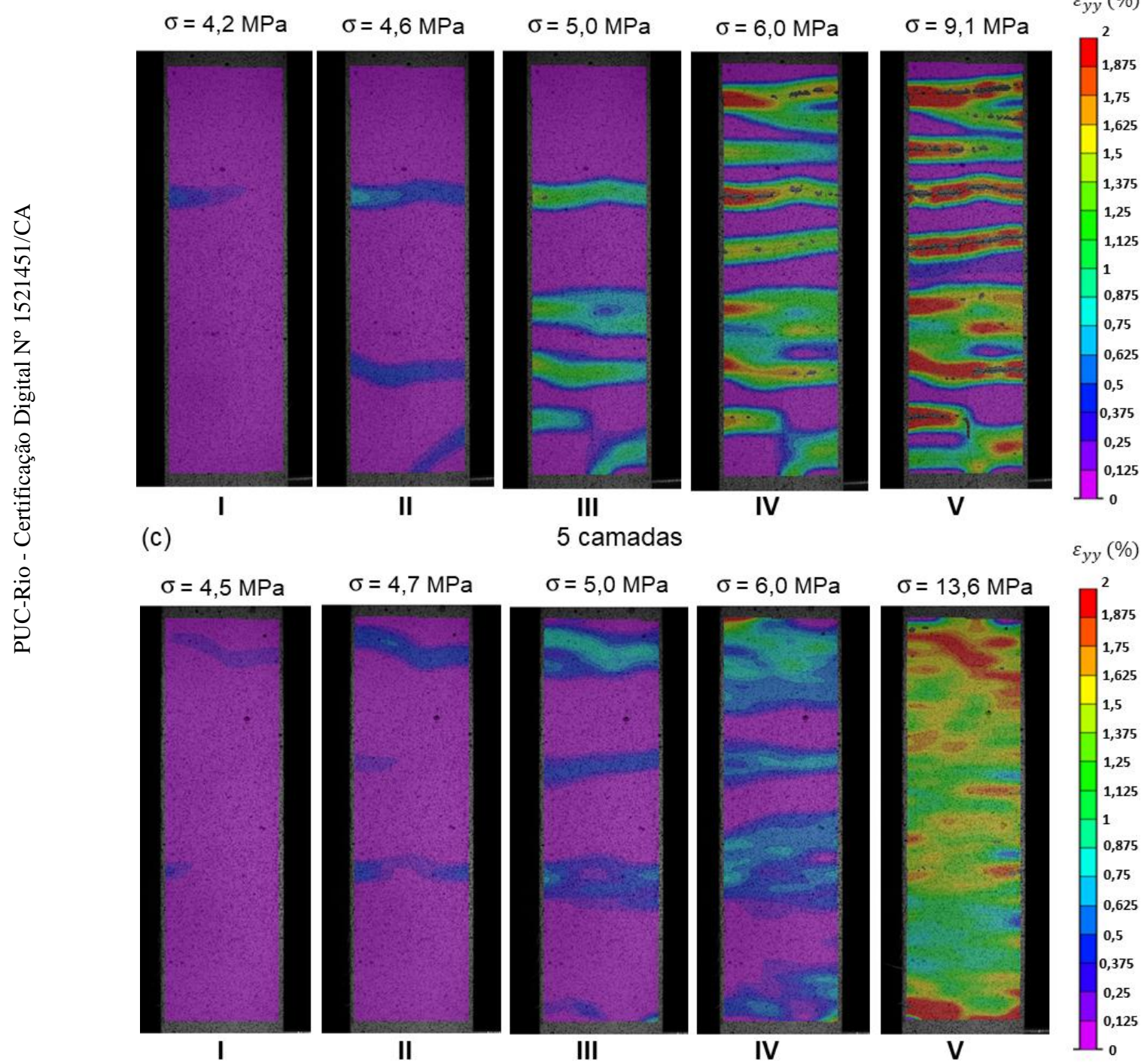

Figura 4-14 - Campos de deformação em diferentes momentos dos compósitos reforçados com (a) 1 camada; (b) 3 camadas; e (c) 5 camadas. 
Os campos de cada compósito são referentes aos pontos destacados na Figura 4-15. Eles correspondem: ao início da múltipla fissuração (I), a diferentes pontos da múltipla fissuração (II e III), ao final da múltipla fissuração (IV) e aonde o compósito atinge o maior valor de tensão antes da ruptura (V).

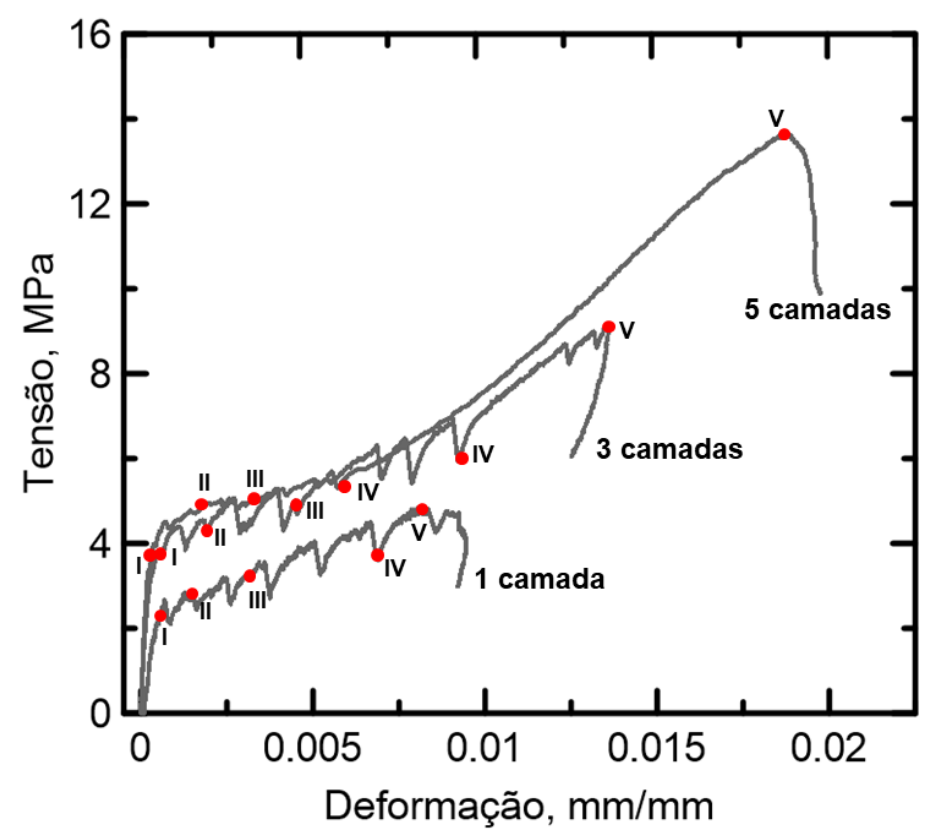

Figura 4-15 - Pontos referentes às imagens analisadas dos compósitos.

A curva do compósito de uma camada não apresentou Zonas II e III bem definidas. Sendo assim, os pontos de avaliação foram espaçados de maneira similar às outras amostras.

Ao analisar os campos de deformações nota-se que as maiores deformações se concentram na vizinhança das fissuras, enquanto que o espaço entre elas apresenta deformação uniforme (regiões rosa). Percebe-se também que primeiro são formadas faixas de cor azul e verde (correspondente a deformações de 0,25 a $1 \%$ ), indicando o início das fissuras na matriz. Mais faixas se formam até a penúltima imagem (final da múltipla fissuração). Da imagem IV (Figura 4-14) para a imagem $\mathrm{V}$ as faixas vermelhas (deformações a partir de 1,75\%) já presentes se alargam e novas regiões com alta deformação são formadas. Há ainda regiões onde não é possível separar visualmente as fissuras, como mostra o detalhe na Figura 4-16. Neste caso, tem-se mais de uma fissura muito pouco espaçadas entre si (aproximadamente $5 \mathrm{~mm}$ ). 


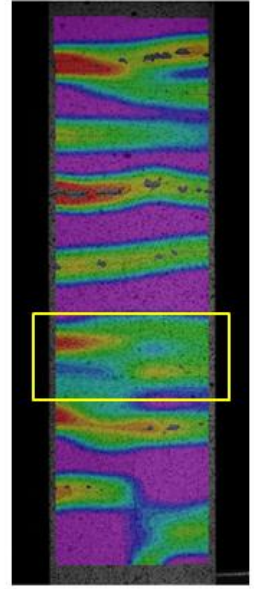

3 camadas - $\mathrm{V}$

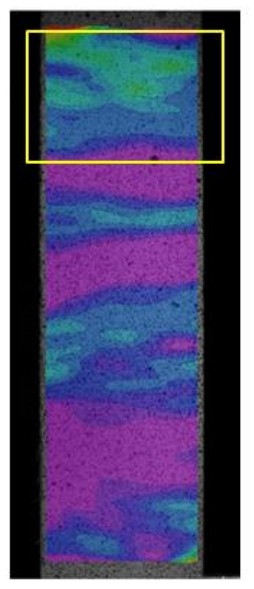

5 camadas - V

Figura 4-16 - Detalhe de regiões que contêm mais de uma fissura.

Apesar do comportamento similar entre os compósitos, as amostras de 1 e 5 camadas de fibra apresentam particularidades. Para o compósito de 1 camada (Figura 4-14 (a)), é possível notar que mesmo com uma tensão atuante de 2,4 MPa na imagem II, não há qualquer deformação maior do que 0,25\%. Cai-se em contradição com a curva tensão versus deformação (Figura 4-15) que neste ponto já apresenta quedas e recuperações de tensão (indicadores de formação de fissuras). Uma possível explicação para isso é que as fissuras que deveriam estar formadas e indicadas nas imagens ocorreram na outra face do compósito, na superfície não contemplada pelas câmeras do DIC. Isso pode explicar porque as regiões de maior deformação (cor vermelha, imagem V) não atravessaram transversalmente toda a amostra: as fissuras estariam localizadas principalmente na face oposta à analisada.

O compósito de 5 camadas não apresenta, praticamente, nenhuma região vermelha (deformações a partir de 1,75\%) mesmo submetido a tensões de $6 \mathrm{MPa}$ (imagem IV), ao final da múltipla fissuração. A grande quantidade de regiões azuis e verdes (deformações entre 0,25 a $1 \%$ ) caracterizam fissuras muito pequenas que só irão se localizar a partir desse momento até o ponto de máxima tensão (imagem V). Ao final do ensaio pode-se observar que toda a superfície analisada está sob diferentes valores de deformação, maiores do que $0,25 \%$, caracterizando uma região de fissuras muito pouco espaçadas de abertura pequena. 


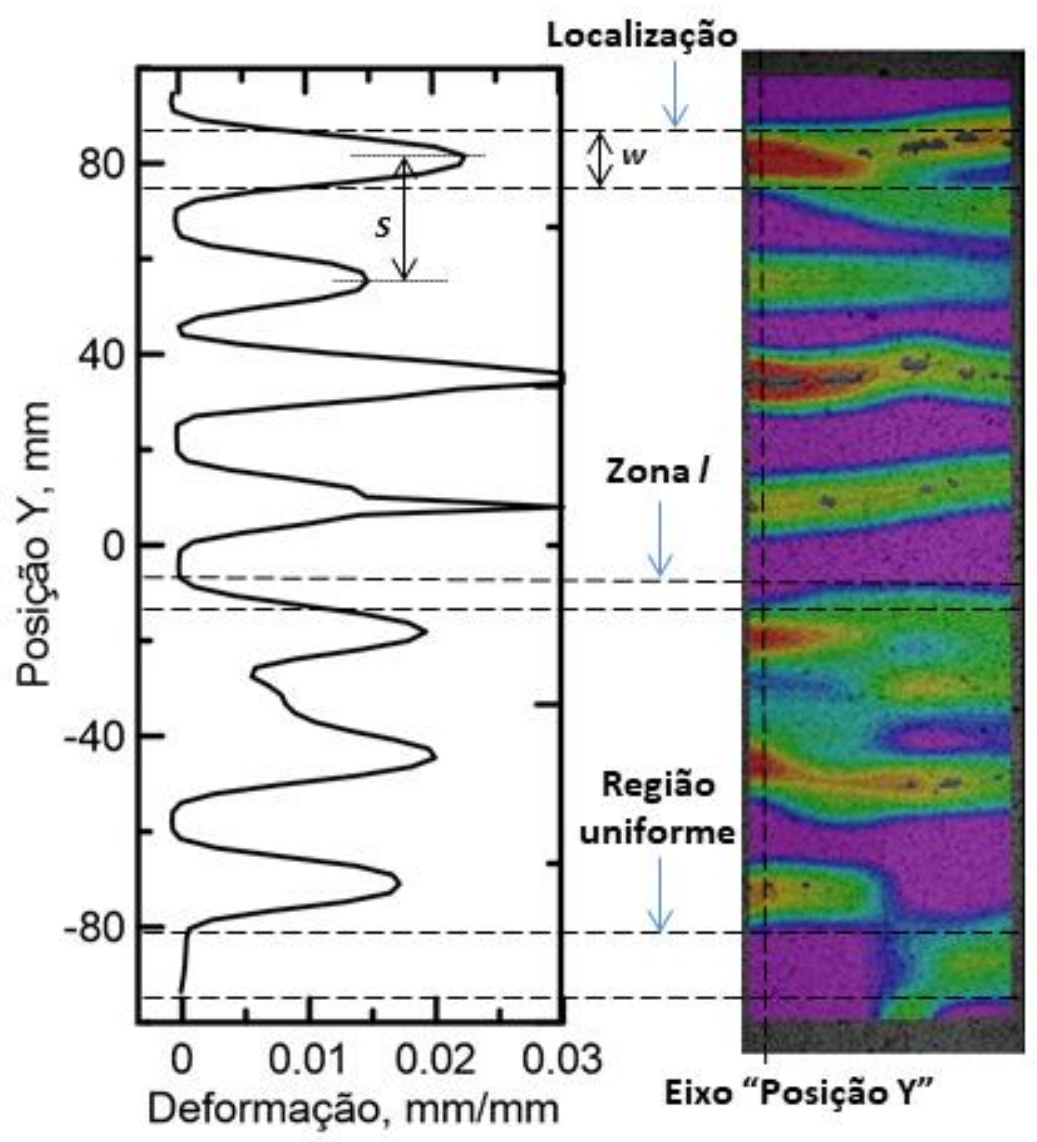

Figura 4-17 - Identificação de três zonas: localização, "l" e região uniforme no campo de deformações

A Figura 4-17 mostra a identificação de três zonas no campo de deformações:

i. Zona de Localização, evidenciada pela zona vermelha, onde a fissura é localizada e as tensões são suportadas basicamente pelo tecido;

ii. Zona de "shear lag", região nas cores azuis e verdes ao longo das maiores concentrações de deformação, onde a matriz se encontra ancorada pelo tecido. O termo "shear lag" foi utilizado por Rambo et al. [114] para definir essa zona;

iii. Zona de deformação uniforme, região rosa, onde não há presença de fissuras, onde a tensão de tração atuante é menor do que a resistência à tração da matriz.

Essas zonas podem ser relacionadas a respostas constitutivas do material [114]. Além disso, pode-se identificar o espaçamento entre fissuras $(s)$ e a espessura média de uma fissura que relaciona o comprimento $w$ com a deformação máxima naquele ponto. $\mathrm{O}$ espaçamento $s$ pode ser representativo se a 
amostra não possuir regiões de sobreposição de fissuras, como na Figura 4-15, pois alguma fissura pode ficar encoberta no gráfico posição Y versus deformação.

A distribuição das deformações de tração ao longo do eixo axial das amostras para os mesmos instantes (I, II, III, IV e V) que na Figura 4-15 é mostrada na Figura 4-18. Nela pode-se observar a evolução da deformação bem como a tensão em cada momento.

(a)

\section{1 camada}

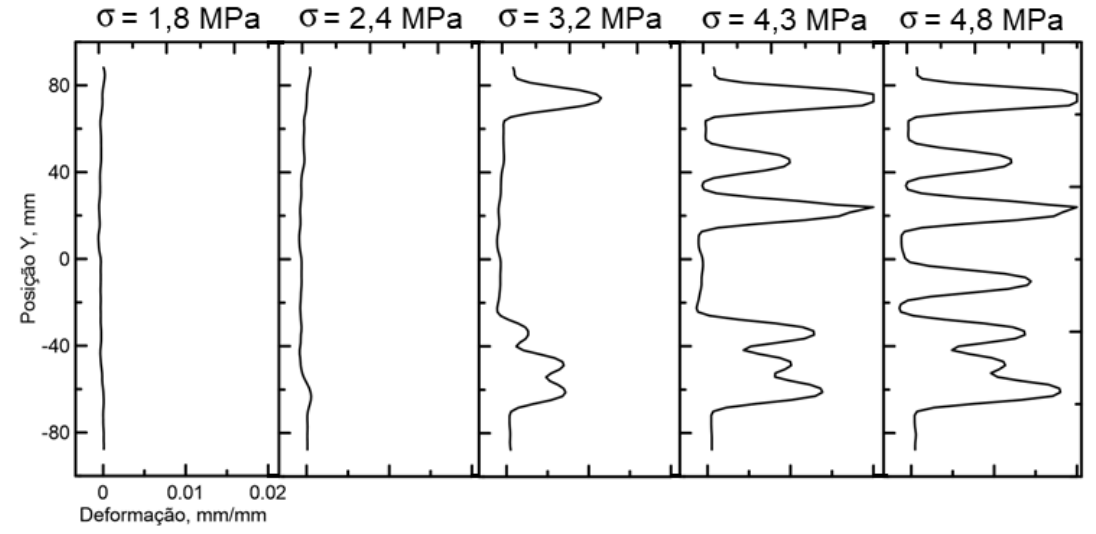

(b)

3 camadas

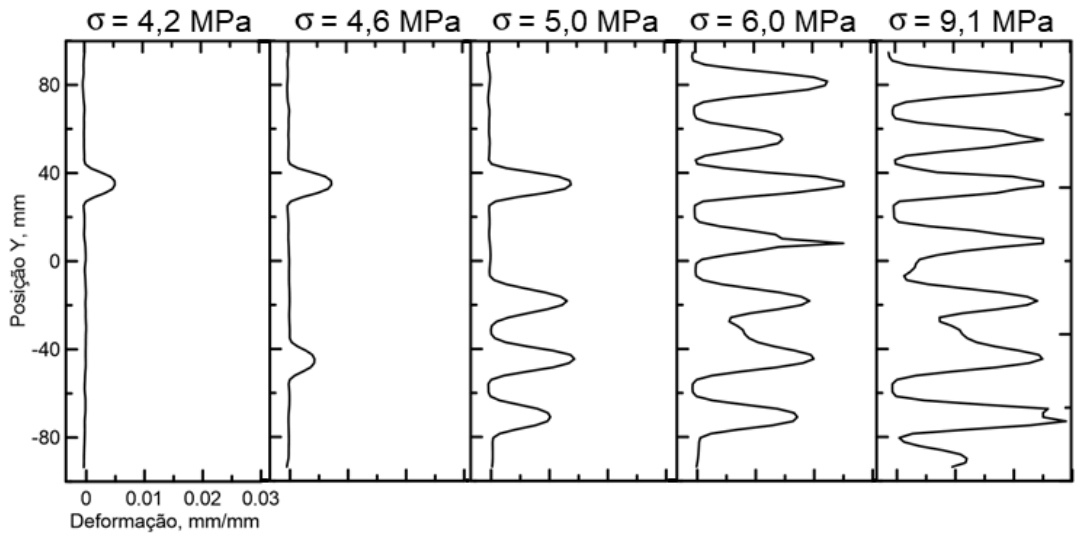

(c)

5 camadas

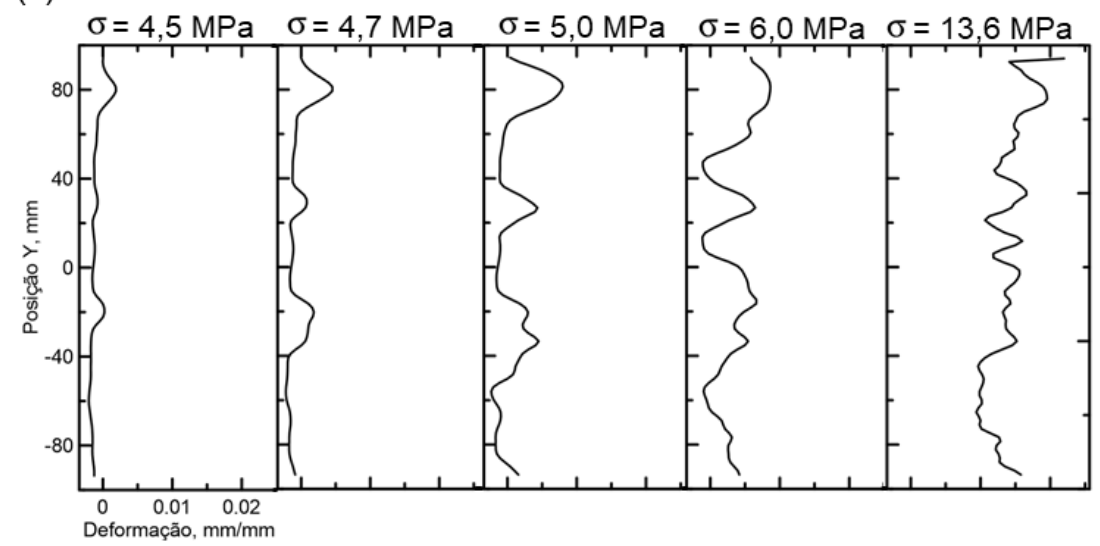

Figura 4-18 - Posição Y versus deformação para os compósitos reforçados com (a) 1 camada; (b) 3 camadas; e (c) 5 camadas de tecido de curauá. 
Quando os valores de deformação são tais que causam descontinuidade na área analisada, os valores fornecidos pelo DIC são zero. Para melhor visualização das curvas, foram escolhidos valores fixos, próximos dos valores de deformação anteriores. Portanto, para deformações excessivas, seus valores não são confiáveis.

O acompanhamento do tamanho de fissuras durante os ensaios é difícil de ser realizado somente por análise de imagens por se tratar de pequenas fissuras. A resolução das fotos não se mostrou suficiente para tal medição. Assim, realizou-se uma estimativa da abertura média da fissura, como descrito no item 4.2.2.1. Valores de abertura média de fissuras para os distintos compósitos foram comparadas para um mesmo nível de tensão, 4,8 $\mathrm{MPa}$ e os resultados se encontram na Tabela 4-4.

Tabela 4-4 - Abertura média das fissuras dos três tipos de compósitos ao nível de 4,8 MPa por visualização das curvas de deformação geradas pelo DIC.

\begin{tabular}{c|c}
\hline Compósito & Abertura média $(\mu \mathrm{m})$ \\
\hline 1 camada & 337 \\
3 camadas & 122 \\
5 camadas & 19 \\
\hline
\end{tabular}

A Figura 4-19 mostra o padrão de fissuração gerado pelos dados do DIC ao final dos ensaios contraposto com o padrão de fissuração real medido após o término dos mesmos com auxílio do microscópio esteroscópico. 


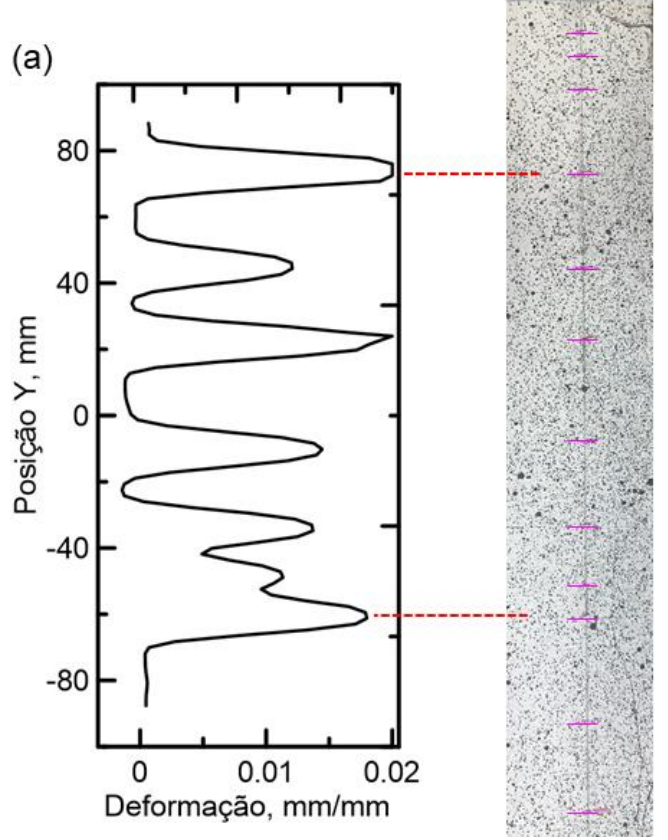

(b)

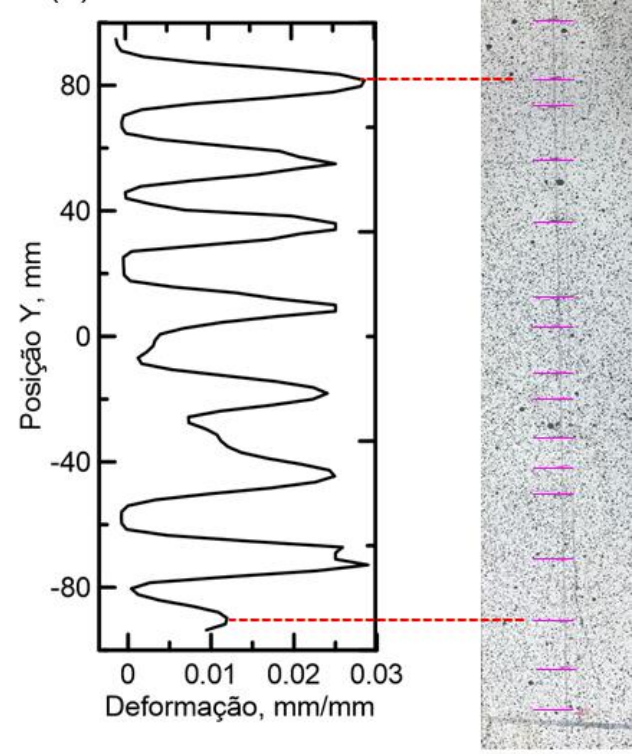

(c)

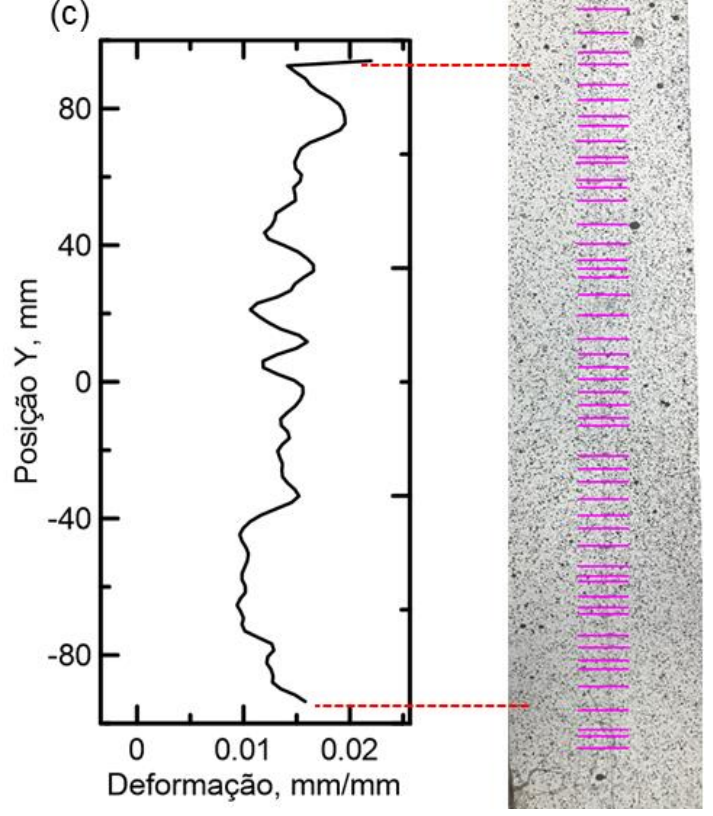

Figura 4-19 - Comparação entre o padrão de fissuração gerado pelo DIC com o padrão de físsuração real após o término do ensaio dos compósitos reforçados com (a) uma camada; (b) três camadas; e (c) cinco camadas de tecido de curauá

A partir da Figura 4-19, observa-se que a área de interesse se refere a uma parte do corpo de prova por conta da distância que as lentes precisam ficar e pela adição dos suportes dos LVDTs. Assim, nem todas as fissuras de uma face são contabilizadas. Para os compósitos reforçados com uma e três camadas, o 
espaçamento $s$ (Figura 4-17) retirado das curvas de deformação versus Posição Y representa uma boa aproximação do espaçamento real. $\mathrm{O}$ mesmo não pode ser aplicado para o compósito de cinco camadas.

Uma comparação é feita entre os compósitos reforçados com tecido unidirecional de curauá, caracterizado neste trabalho, com outros tipos de compósitos encontrados na literatura. A comparação é mostrada na Figura 4-20. Buscou-se compósitos com dimensões semelhantes e ensaiados de maneira análoga.

(a)

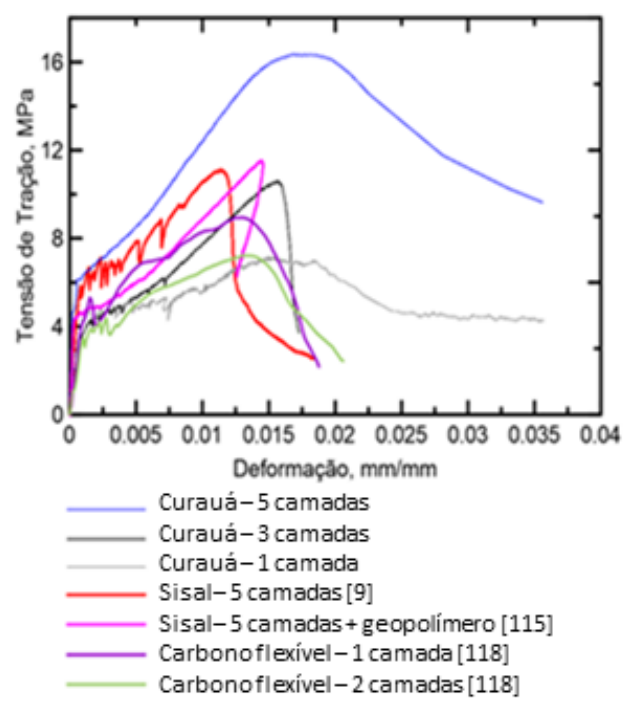

(b)

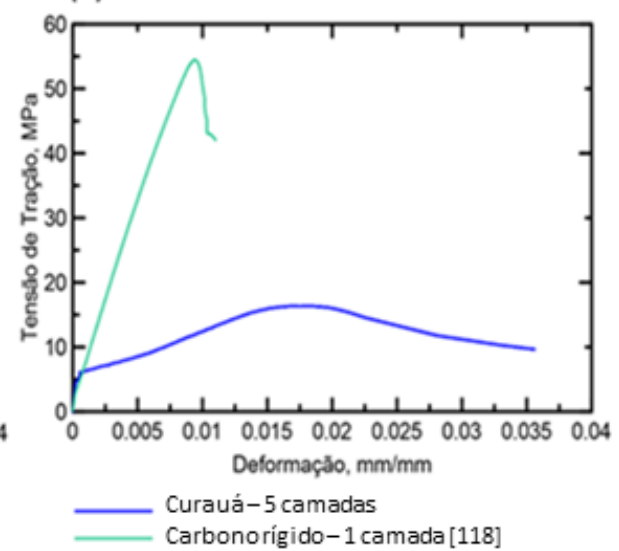

Figura 4-20 - Comparação entre diferentes compósitos solicitados à tração direta.

As curvas em linha cinza, preta e azul (Figura 4-20 (a)) são as dos compósitos estudados neste trabalho, com uma, três e cinco camadas de tecido unidirecional de curauá. A curva em vermelho é a resposta de um compósito com características similares ao reforçado com curauá, mas usando outra fibra natural como tecido também unidirecional, o sisal [9]. Pode-se observar que, apesar de ser reforçado com cinco camadas de sisal, o comportamento da curva vermelha se aproxima mais daquele reforçado com três camadas de curauá, apresentando fissuras maiores, evidenciadas pelas maiores quedas de tensão. Quando comparado ao compósito reforçado com cinco camadas de tecido unidirecional de sisal, mas de matriz geopolimérica [115], o comportamento se assemelha mais uma vez com o compósito reforçado com três camadas de curauá. Já as curvas em verde e roxo são referentes a compósitos reforçados com tecido de carbono com 
uma e duas camadas [118]. Mesmo com esse tecido sintético, o compósito com cinca camadas de curauá possui melhor desempenho mecânico. Quando comparado com compósito cimentícios reforçado com tecido de carbono do tipo rígido (Figura 4-20 (b)), aquele reforçado com curauá (curva azul) apresenta tanto resistência quanto rigidez inferiores.

\subsubsection{Comportamentos dos compósitos à flexão e seus mecanismos de fissuração}

A Figura 4-21 mostra a resposta dos três compósitos sob o ensaio de flexão a quatro pontos com os respectivos espaçamentos entre fissuras. Todos eles apresentaram comportamento conhecido como deflection hardening. A rigidez dos compósitos também aumenta quando a fração volumétrica aumenta, mesmo comportamento apresentado pelos compósitos quando submetidos à tração.

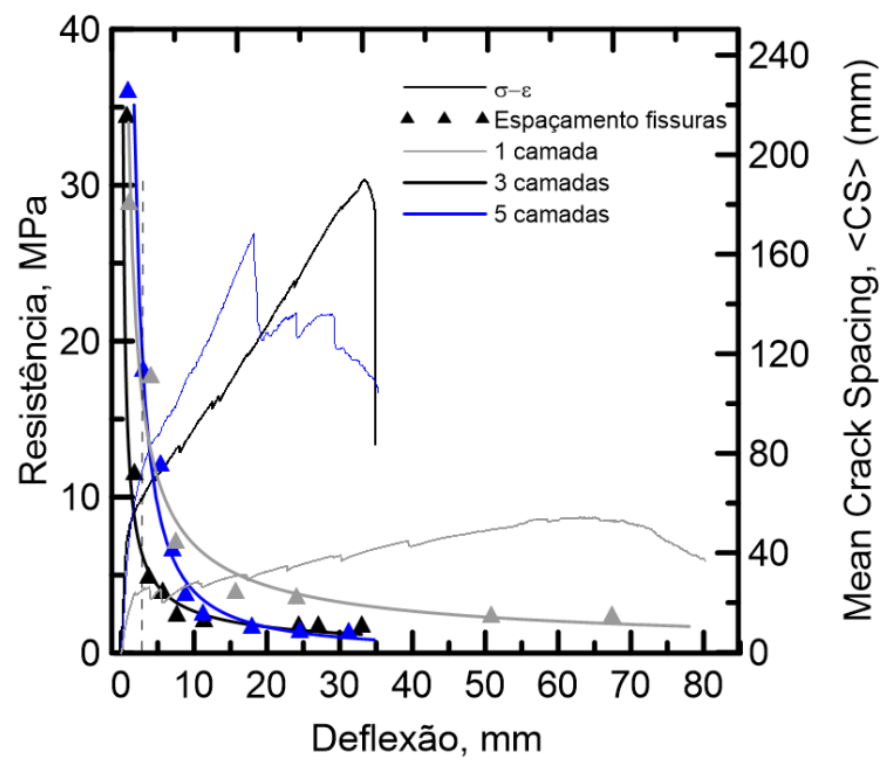

Figura 4-21 - Resposta dos três tipos de compósitos sob flexão a quatro pontos e seus respectivos espaçamentos entre fissuras.

Após o ensaio, uma amostra de cada tipo de compósito foi levada ao microscópio estereoscópio para medição da abertura das fissuras. A Tabela 4-5 mostra a média das fissuras formadas ao longo do eixo longitudinal central da parte inferior do corpo de prova. 
Tabela 4-5 - Abertura média das fissuras formadas no centro dos compósitos após o ensaio de flexão.

\begin{tabular}{c|c|c|c}
\hline Compósito & $N^{o}$ de fissuras & Tamanho Médio $(\mu \mathrm{m})$ & Espaçamento $(\mathrm{mm})$ \\
\hline 1 camada & 17 & 60 & 9,6 \\
3 camadas & 23 & 50 & 8,5 \\
5 camadas & 35 & 25 & 5,4 \\
\hline
\end{tabular}

Os mecanismos de fissuração quando os compósitos são submetidos ao teste de flexão são bem similares ao do teste de tração: primeiramente tem-se uma zona linear elástica, propagação de fissuras até que o espaçamento entre as mesmas se torne saturado, seguido da abertura das fissuras já formadas e a localização de uma só fissura levando o compósito à ruptura. A Tabela 4-6 mostra os valores das propriedades mecânicas analisadas bem como seus respectivos desvios padrões.

Tabela 4-6 - Propriedades mecânicas dos três compósitos quando submetidos ao ensaio de flexão.

\begin{tabular}{l|c|c|c}
\hline Compósito & Tensão Máxima $(\mathrm{MPa})$ & $\begin{array}{c}\text { Deflexão máxima } \\
(\%)\end{array}$ & Tenacidade $(\mathrm{J})$ \\
\hline 1 camada & $10,9 \pm 1,9(17,3 \%)$ & $70,4 \pm 5,2(7,4 \%)$ & $3,8 \pm 0,7(19,2 \%)$ \\
3 camadas & $28,0 \pm 2,0(7,3 \%)$ & $33,7 \pm 0,9(2,6 \%)$ & $16,4 \pm 1,6(10,1 \%)$ \\
5 camadas & $23,7 \pm 3,7(14,4 \%)$ & $19,6 \pm 1,9(9,7 \%)$ & $14,2 \pm 3,5(24,5 \%)$ \\
\hline
\end{tabular}

O modo de ruptura foi diferente para os diversos compósitos estudados. Para as amostras reforçadas com uma e três camadas, a fissura formada na parte tracionada (parte inferior do compósito) cresceu, levando à ruptura por tração. Já para as amostras reforçadas com cinco camadas, a ruptura ocorreu na porção comprimida do compósito, por esmagamento do concreto (Figura 4-22). 


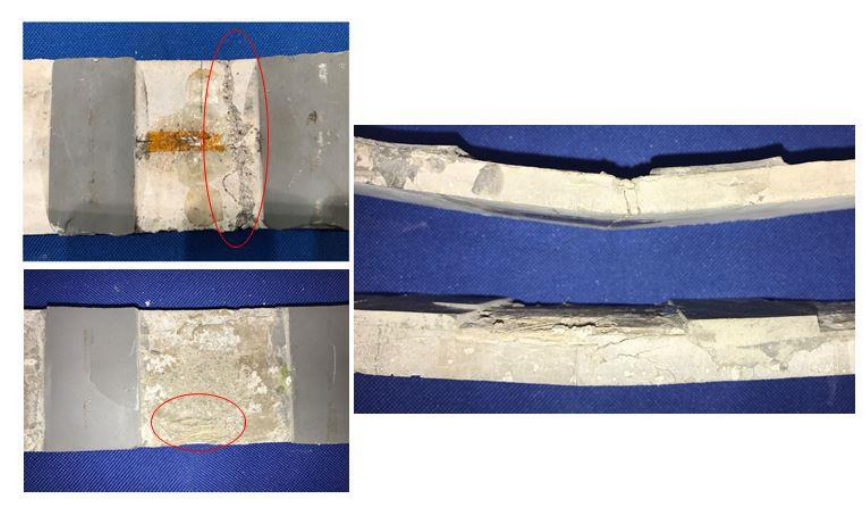

Figura 4-22 - Modos de ruptura dos compósitos de três (acima) e cinco (abaixo) camadas sob flexão. Os círculos vermelhos detalham tanto a fissura localizada no compósito de três camadas quanto a porção de argamassa esmagada no compósito de cinco camadas.

Analisando as deformações obtidas pelos strain gages na Figura 4-23, é possível observar que a zona comprimida (Figura 4-23 (a)) do compósito de cinco camadas apresenta menor rigidez e maiores deformações do que o compósito de três camadas. O compósito reforçado com cinco camadas, possui a parte comprimida rompendo aos $2 \%$ de deformação, que normalmente corresponde ao pico de deformação no diagrama tensão versus deformação. Já as deformações na zona tracionada (Figura 4-23 (b)) apresenta um comportamento mais linear e com maior rigidez para o compósito de cinco camadas.

(a)

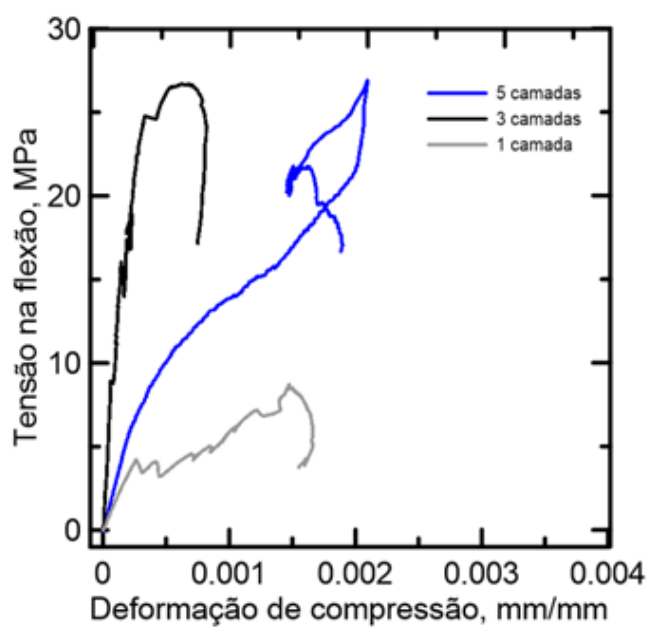

(b)

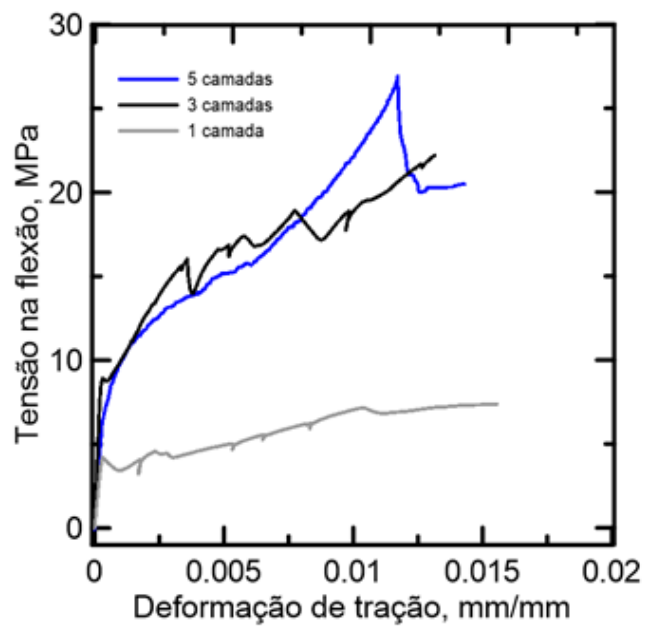

Figura 4-23 - Deformações (a) de compressão e (b) de tração dos compósitos reforçados com tecidos de curauá. 
O comportamento observado pelos dados obtidos pelos strain gages pode ajudar a explicar os valores de resistência neste ensaio. O compósito de três camadas apresentou maior valor de resistência do que o de cinco camadas, indicando que possivelmente este não teve sua capacidade de resistir a tensões de tração aproveitadas totalmente. Comparando essa curva com aquela obtida no ensaio de tração (Figura 4-11), pode-se perceber que o compósito de cinco camadas tem o comportamento bem superior ao de três camadas quando ele não está submetido a tensões de compressão. O mesmo não acontece com o compósito de uma camada provavelmente por conta de sua esbeltez que permite uma deformação maior, sem que haja concentração de tensões (Figura 4-24).

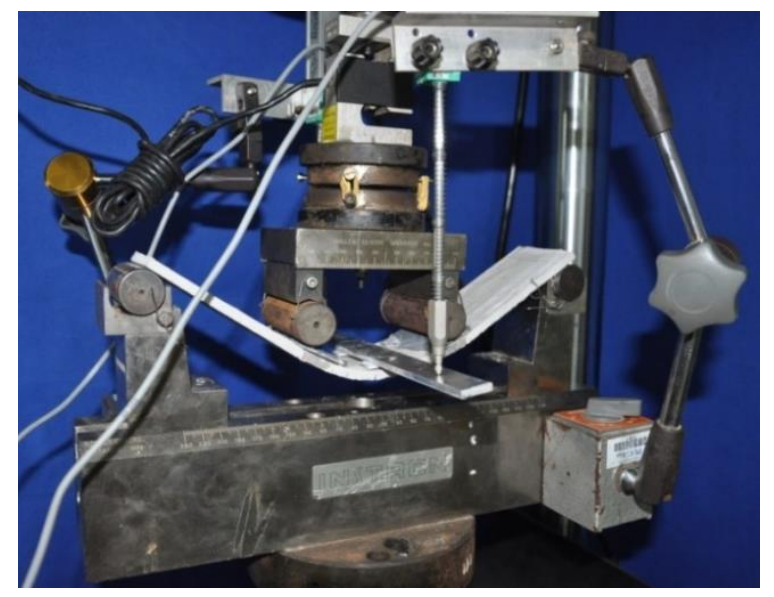

Figura 4-24 - Final do ensaio de flexão do compósito reforçado com uma camada.

Outra forma de avaliar o comportamento mecânico dos compósitos sob flexão é por meio do comportamento da linha neutra dos mesmos, como mostrado na Figura 4-25. A partir das deformações obtidas pelos strain gages (valores extremos superior e inferior), é possível calcular a altura da linha neutra considerando que as seções permanecem planas (Euler-Bernoulli). Os valores da linha neutra foram normalizados, sendo que o valor 1 corresponde ao extremo inferior (parte tracionada no ensaio de flexão) e que o valor o corresponde ao extremo superior. 


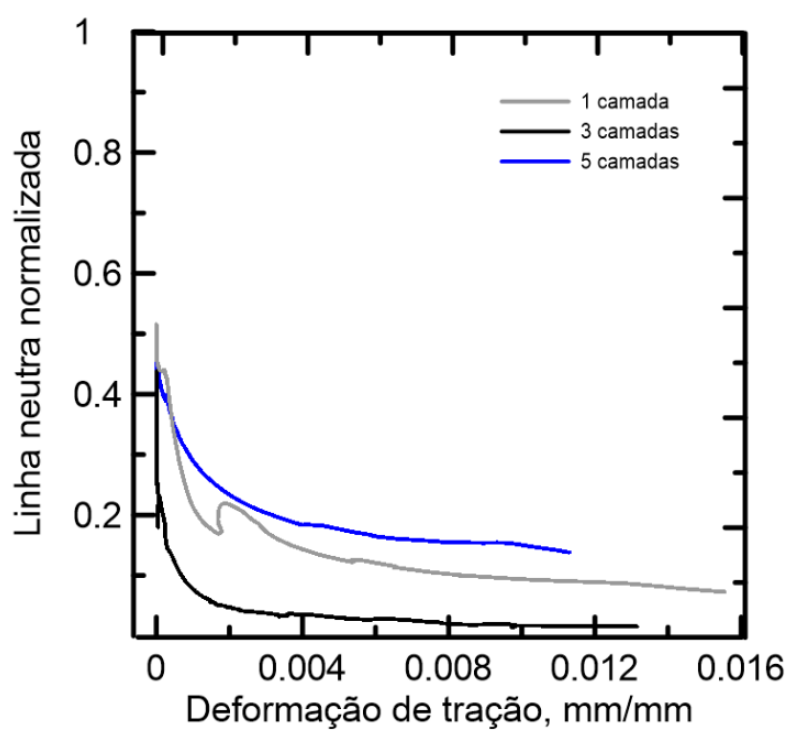

Figura 4-25 - Desenvolvimento da linha neutra normalizada dos três compósitos.

A partir das curvas mostradas na Figura 4-25, é possível perceber que logo no início do ensaio, a linha neutra normalizada tem seu valor aproximado de 0,5. Como o compósito com uma camada de tecido foi aquele que mais se deformou, sua linha neutra correspondente foi a que apresentou mais variações e o strain gage inferior se manteve íntegro até a metade do ensaio. Apesar disso, é clara a tendência da linha neutra, se encaminhar para o topo do corpo de prova (linha neutra normalizada $=0$ ). O compósito de três camadas apresentou a linha neutra próxima de 0 (topo da amostra) por quase toda a deformação, possivelmente indicando a abertura de novas fissuras com profundidade parecida com a primeira fissura. Os strain gages permaneceram íntegros funcionando até $75 \%$ do ensaio. Já o compósito de cinco camadas apresentou fissuras não tão profundas durante boa parte do ensaio, com sua linha neutra normalizada permanecendo a $19 \%$ do topo da amostra (linha neutra $=0,19)$ até o final do ensaio. Esta linha neutra menos profunda sugere que o compósito está mais sujeito a ruptura por compressão, assim como demostrado em elementos superarmados.

Como as cargas na flexão são suportadas através das fissuras e da redistribuição de tensões, o estudo do comportamento das deformações é necessário. A partir das curvas da Figura 4-25, pode-se observar que cálculos feitos considerando a linha neutra a 0,5 da espessura, ou seja, seção não fissurada, superestimam a capacidade do material. 


\subsection{Conclusões}

Todos os compósitos reforçados com tecido unidirecional de curauá apresentaram comportamento strain hardening e deflection hardening, com formação de múltiplas microfissuras.

Nas curvas obtidas de ambos os ensaios mecânicos, cinco Zonas foram identificadas a partir da análise de imagens e relacionadas com a tensão atuante e com a formação de fissuras, bem como o espaçamento entre elas. Mesmo que a rigidez tenha diminuído na pós-fissuração se comparada com o Módulo de Young, os compósitos chegaram a valores altos de resistência máxima. O compósito que teve melhor comportamento foi o de 5 camadas: altos valores de tensão máxima e BOP+, 14,7 MPa e $6 \mathrm{MPa}$, respectivamente. Já no ensaio de flexão, apesar do compósito de 5 camadas apresentar a maior rigidez, é o de 3 camadas que apresenta o maior valor de tensão máxima, $28 \mathrm{MPa}$. Os compósitos apresentaram modos de ruptura diferentes entre si durante o ensaio de flexão: aqueles com uma e três camadas romperam por tração e os de cinco camadas por compressão. O comportamento da linha neutra, calculada a partir das deformações dos straingages, permitiu observar a menor profundidade que as fissuras do compósito de cinco camadas atingiram, estando de acordo com seu modo de ruptura.

O método de DIC foi usado para melhor acompanhamento da formação das fissuras e para uma estimativa do tamanho das mesmas durante o ensaio de tração. Análises a respeito dos campos de deformação longitudinal foram feitas, assim como correlações entre a distribuição de deformação ao longo de um eixo das amostras. Apesar de não ter sido conclusivo para o compósito de uma camada, diferenças entre a formação e distribuição das fissuras daqueles reforçados com três e cinco camadas foram evidenciadas. 


\section{Capacidade de autocicatrização do compósito reforçado por três camadas de tecido unidirecional de curauá}

\subsection{Introdução}

A escolha do compósito para essa parte da pesquisa se baseou em alguns critérios. Um deles é o comportamento mecânico de flexão a quatro pontos que seria utilizado para analisar a capacidade de autocicatrização. O compósito que teve melhores resultados de comportamento nesse ensaio foi o de três camadas. Outro critério foi o do tamanho das fissuras. Neste critério, o compósito que teve menor abertura média foi o de cinco camadas. Entretanto, outro ponto levantado foi a questão do consumo de materiais. Apesar das menores fissuras, o compósito de cinco camadas requer maior quantidade de fibras e os procedimentos que envolvem o preparo das mesmas são demorados. Assim, combinando o bom comportamento na flexão com aberturas pequenas, média de $50 \mu \mathrm{m}$, e consumo mediano de material, o compósito de três camadas foi escolhido para o estudo da capacidade de autocicatrização.

Dois ensaios foram realizados: cíclico e de carregamento constante, submetidos a diferentes condições de exposição. As fissuras foram observadas ao final de cada ensaio a fim de acompanhar a evolução das mesmas.

\subsection{Procedimento experimental}

\subsubsection{Ensaios}

A fim de ter uma abordagem mais próxima daquela que o material sofre durante seu uso, dois ensaios foram escolhidos:

- Ensaio cíclico, pensando no material submetido a carregamentos repetidos;

- Ensaio de carregamento contínuo, simulando as cargas atuantes permanentes.

Ambos os ensaios foram realizados utilizando a máquina e o arranjo experimental do ensaio de flexão a quatro pontos, descritos no item 4.2.2.2 deste 
trabalho. A fabricação dos compósitos reforçados com três camadas de tecido unidirecional de curauá se deu da mesma forma descrita no item 4.2.1.

As amostras em ambos os testes foram expostas a duas condições: sem a presença de água e com a presença de pouca quantidade de água. Durante todo o tempo de exposição, as amostras ficaram em sala com temperatura e umidade controladas com valores de $20^{\circ} \mathrm{C} \pm 2^{\circ} \mathrm{C}$ e $55 \% \pm 5 \%$, respectivamente.

\subsubsection{Carregamento contínuo}

As amostras foram pré-fissuradas na idade de 28 dias até o atuador atingir $10 \mathrm{~mm}$ de deslocamento e descarregadas. Posteriormente elas foram deixadas durante 28 dias na sala de temperatura e umidade controladas submetidas a diferentes condições. Após os 28 dias de exposição, as amostras foram carregadas até a ruptura. As condições de exposição se encontram na Figura 5-1.

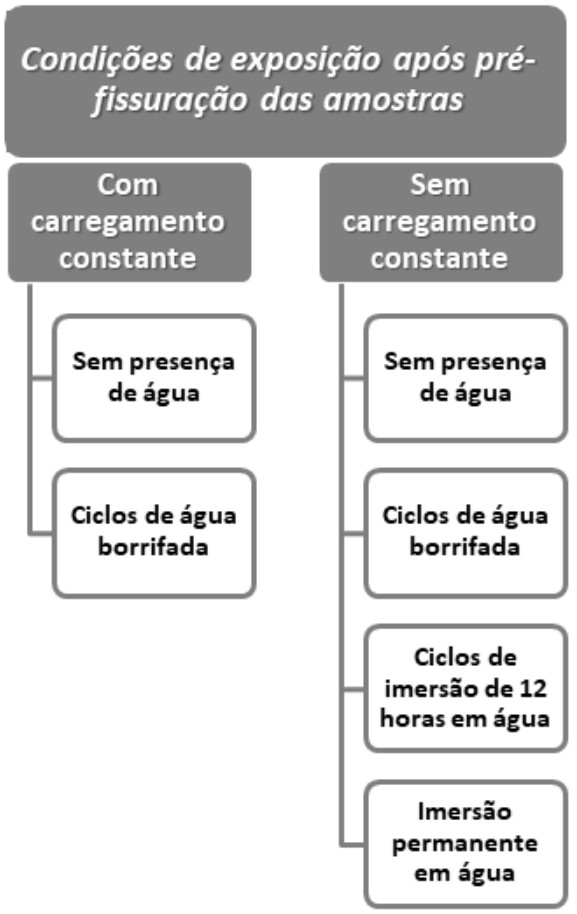

Figura 5-1 - Esquematização das condições que as amostras foram expostas durante 28 dias após a pré-fissuração. Todos os procedimentos ocorreram dentro de sala com ambiente controlado.

O valor do carregamento constante foi determinado para cada corpo de prova. Ao final da pré-fissuração, as cargas correspondentes aos valores dos deslocamentos máximos foram adicionadas sobre as amostras. O carregamento 
não foi aplicado de uma só vez, e, sim, em sequências de $100 \mathrm{~N}$ ou menos, quando necessário. Os valores de carga e tensão correspondente para cada amostra se encontra na Tabela 5-1.

Tabela 5-1 - Valor das cargas adicionadas em cada amostra para o ensaio de carga contínua.

\begin{tabular}{c|c|c|c}
\hline Condição & Amostras & $\begin{array}{c}\text { Carga constante } \\
\text { durante o mês }(N)\end{array}$ & $\begin{array}{c}\text { Tensão Equivalente } \\
(\mathrm{MPa})\end{array}$ \\
$\begin{array}{c}\text { Sem } \\
\text { presença de }\end{array}$ & 01 & 350 & 11,3 \\
água & 02 & 350 & 12,9 \\
\cline { 1 - 2 } Ciclos de & 03 & 310 & 11,3 \\
água & 02 & 310 & 9,0 \\
borrifada & 03 & 290 & 9,5 \\
\hline
\end{tabular}

Os pontos de aplicação de carga do arranjo experimental de flexão foram simulados com roletes na sala onde as amostras permaneceram. O arranjo teve que ser elevado por conta do monitoramento das fissuras ao longo do ensaio e para ser possível borrifar água em todas as faces das amostras. A Figura 5-2 mostra o arranjo com o carregamento contínuo aplicado e o posicionamento do LVDT.

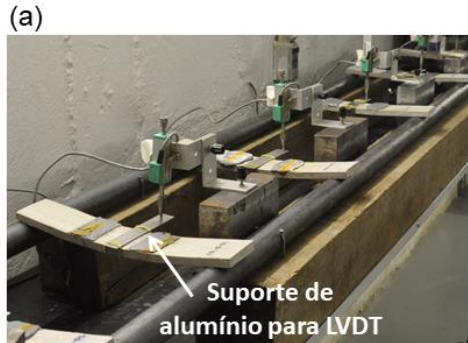

(c)

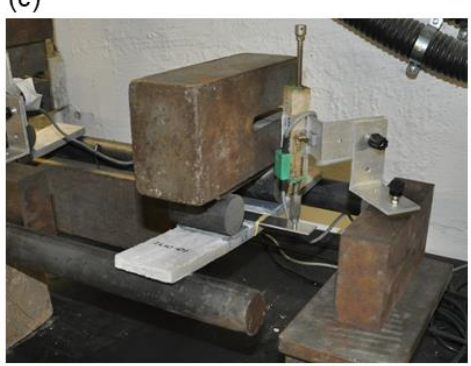

(b)

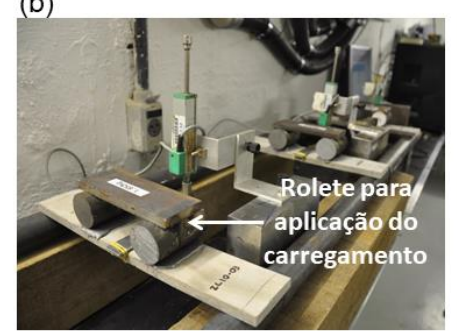

(d)

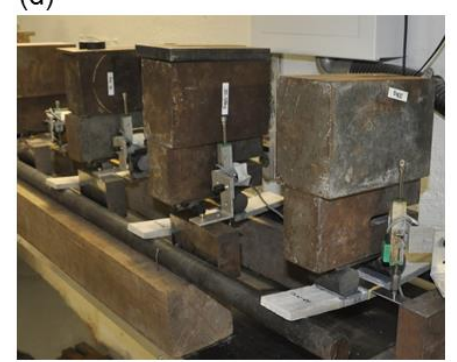

Figura 5-2 - Arranjo experimental usado no ensaio de carregamento constante: (a) suporte para apoio do LVDT; (b) rolete para distribuição da carga nos mesmos pontos do carregamento de pré-fissuração; (c) início do carregamento e (d) amostras totalmente carregadas. 
Um LVDT foi posicionado no centro do vão para cada amostra submetida ao carregamento contínuo e o deslocamento foi aquisitado ao longo dos 28 dias. A taxa de aquisição foi de 0,1 hertz (uma leitura a cada 10 segundos) nas primeiras 48 horas e de 0,02 hertz (uma leitura a cada 50 segundos) no restante do ensaio.

Como visto na Figura 5-1, uma das condições de exposição foram os ciclos de água borrifada. Tal condição consistia em borrifar aproximadamente 30 mililitros de água em cada corpo de prova ao longo de um dia. Ou seja, durante 24 horas as amostras eram expostas ao ambiente da sala $\left(\mathrm{T}=20^{\circ} \mathrm{C} \pm 2^{\circ} \mathrm{C}\right.$ e $\mathrm{UR}=55 \% \pm$ $5 \%$ ) e durante as 24 horas seguintes elas eram borrifadas. A fim de melhor analisar os efeitos da quantidade de água no fechamento das fissuras e no comportamento dos compósitos, outras condições também foram impostas. Assim, ciclos de 12 horas de imersão em água seguidas de 12 horas em ambiente controlado da sala, bem como imersão em água durante 28 dias completam as condições as quais as amostras sem carregamento contínuo foram expostas.

Fissuras no centro de cada amostra foram monitoradas ao longo do ensaio utilizando-se um microscópio estereoscópico portátil, como mostra a Figura 5-3.

(a)

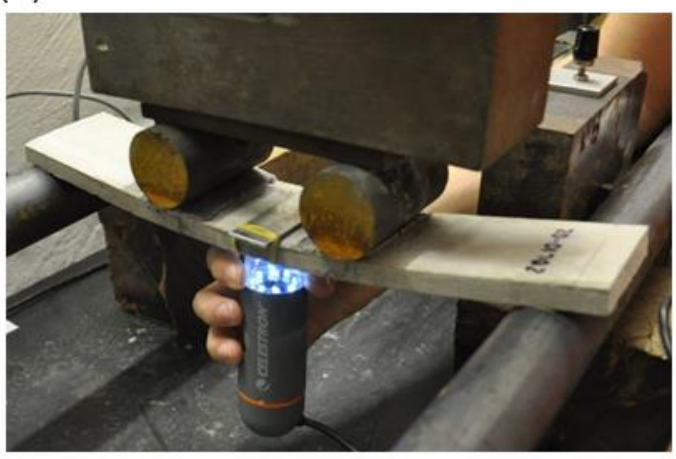

(b)

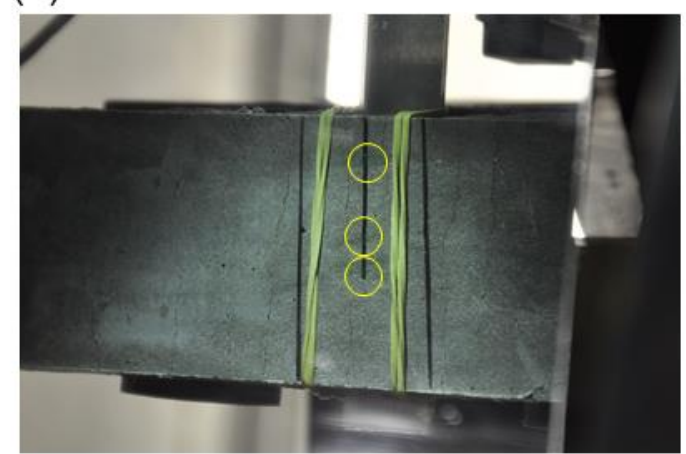

Figura 5-3 - Monitoramento de fissuras durante o ensaio de carga contínua com o uso de um microscópio estereoscópico portátil (a) e localização das fissuras que foram acompanhadas ao longo do ensaio (b).

Lâminas delgadas foram utilizadas para verificar deposição de produtos nas fissuras. Três lâminas delgadas de dimensões $45 \mathrm{~mm}$ x $25 \mathrm{~mm}$ x $30 \mu \mathrm{m}$ foram retiradas de uma amostra sem carga contínua que passou pelos 12 ciclos de água borrifada. As amostras foram cortadas, impregnadas com resina epóxi e desgastadas até espessura de $30 \mu \mathrm{m}$. O procedimento de preparação foi realizado pela empresa Solintec. As lâmicas foram analisadas em microscópio ótico Leica DM LP, da empresa Solintec sob luz polarizada simples e cruzada. A Figura 5-4 
(a) mostra de quais partes do compósito foram retiradas as amostras bem como a orientação das mesmas.

(a)

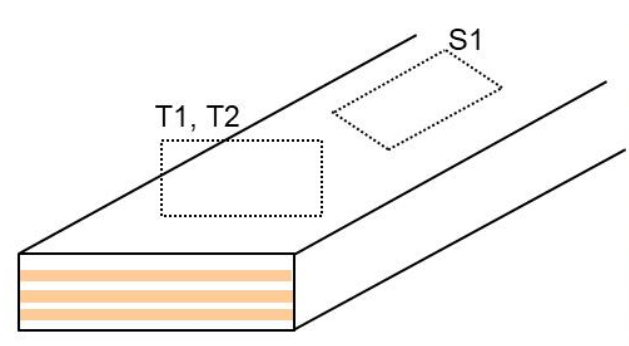

(b)

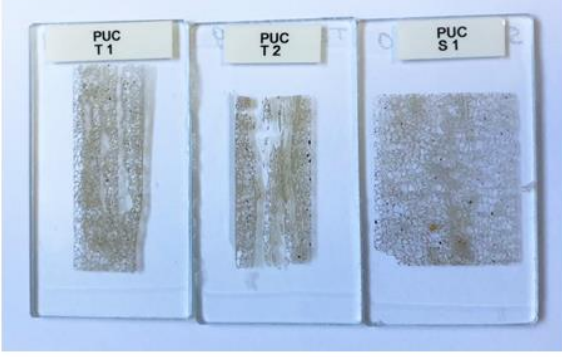

Figura 5-4 - (a) Localização e orientação das amostras; e (b) lâminas delgadas.

\subsubsection{Cíclico}

Para este ensaio, dois níveis de deslocamento foram escolhidos, $10 \mathrm{~mm}$ e 20 mm. A escolha desses deslocamentos foi feita a partir do comportamento apresentado pelo compósito de três camadas nos ensaios de flexão (item 4.3.2). Como a tensão máxima (28,0 MPa) ocorreu em aproximadamente $30 \mathrm{~mm}$ de deflexão, adotou-se um e dois terços deste valor como os níveis de deslocamento para o ensaio cíclico (Figura 5-5).

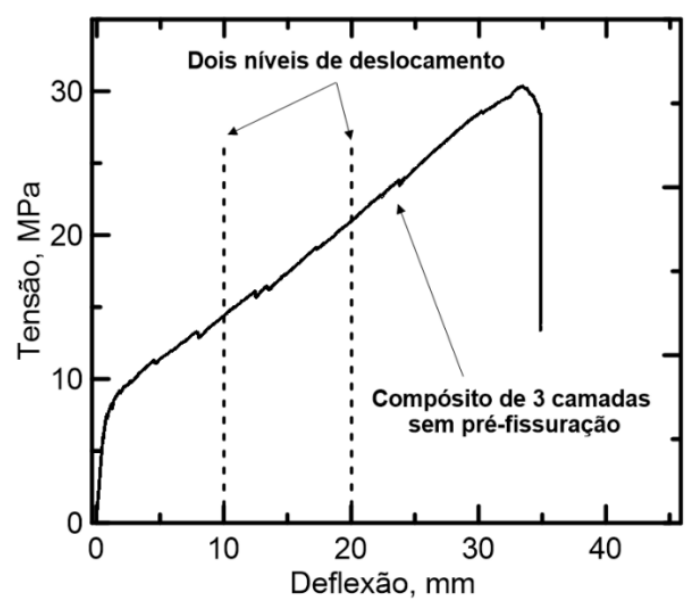

Figura 5-5 - Comportamento do compósito com três camadas de fibra de curauá submetido ao ensaio de flexão. Níveis de deslocamento adotados no ensaio cíclico, 10 e $20 \mathrm{~mm}$, indicados

Para todos os níveis de deslocamento e exposição, o primeiro ensaio ocorreu aos 28 dias de idade. O procedimento realizado foi o seguinte: 
i) As amostras foram moldadas, curadas e retiradas da água um dia antes do ensaio para serrar as laterais, como no ensaio de flexão (item 4.2.2.2) e posterior colocação de massa plástica;

ii) As mesmas foram ensaiadas até o deslocamento pré-determinado;

iii) Após o ensaio, elas foram retiradas do arranjo experimental e colocadas na sala com controle de temperatura e umidade $\left(\mathrm{T}=20^{\circ} \mathrm{C}\right.$ $\pm 2^{\circ} \mathrm{C}$ e $\mathrm{UR}=55 \% \pm 5 \%$ ) por 28 dias;

iv) Após os 28 dias na sala de condições controladas, repetiu-se os passos ii) e iii) por mais duas vezes;

v) Ensaiaram-se as amostras até a ruptura.

Um arranjo experimental com dois roletes foi montado na sala onde as amostram ficaram expostas a fim de manter os pontos de apoio do arranjo de flexão, como mostrado na Figura 5-6.

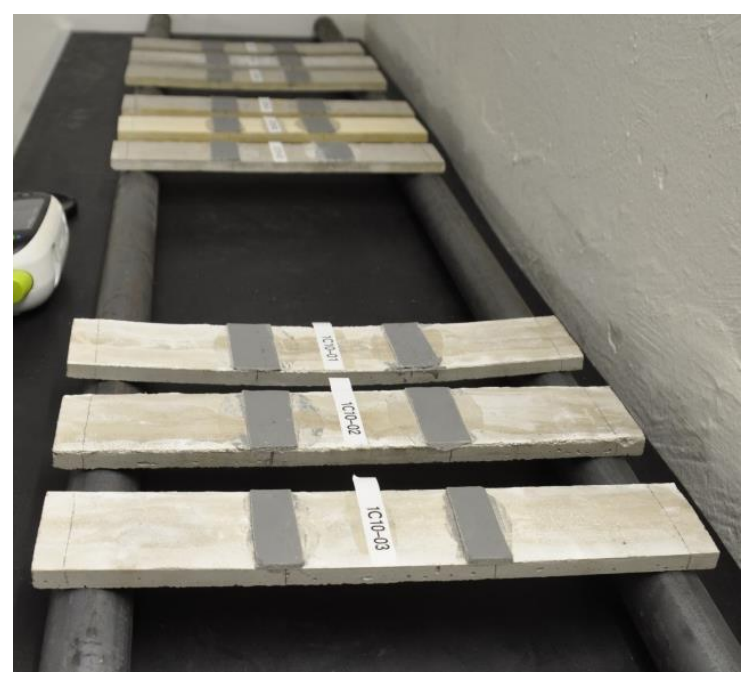

Figura 5-6 - Arranjo experimental para exposição das amostras submetidas ao ensaio cíclico.

Para efeito de comparação, as amostras foram submetidas a duas condições enquanto estavam na sala. Seis amostras, três de cada nível de deslocamento, ficaram submetidas somente às condições da sala. Outras seis amostras, três de cada nível de deslocamento, foram submetidas aos ciclos de água borrifada, como no carregamento contínuo, item 5.2.1.1. Aproximadamente 30 mililitros de água eram borrifados em cada amostra ao longo de um dia. Ou seja, durante 24 horas as amostras eram expostas às condições da sala com temperatura e umidade controladas $\left(\mathrm{T}=20^{\circ} \mathrm{C} \pm 2{ }^{\circ} \mathrm{C}\right.$ e $\left.\mathrm{UR}=55 \% \pm 5 \%\right)$ e durante as 24 horas seguintes elas eram borrifadas. 
As fissuras foram monitoradas após cada ciclo. Uma amostra de cada nível de deslocamento e de cada tipo de exposição foi observada utilizando microscópio estereoscópico (Nikon SMZ800N). Fissuras formadas ao longo de três eixos diferentes do corpo de prova foram localizadas usando cores diferentes para cada ciclo, como mostrado na Figura 5-7. Todas as fissuras visíveis que passaram pelos eixos foram medidas por meio do software NIS-Elements e algumas delas tiveram sua evolução após cada ciclo de ensaio acompanhada por imagens usando o mesmo software.

(a)

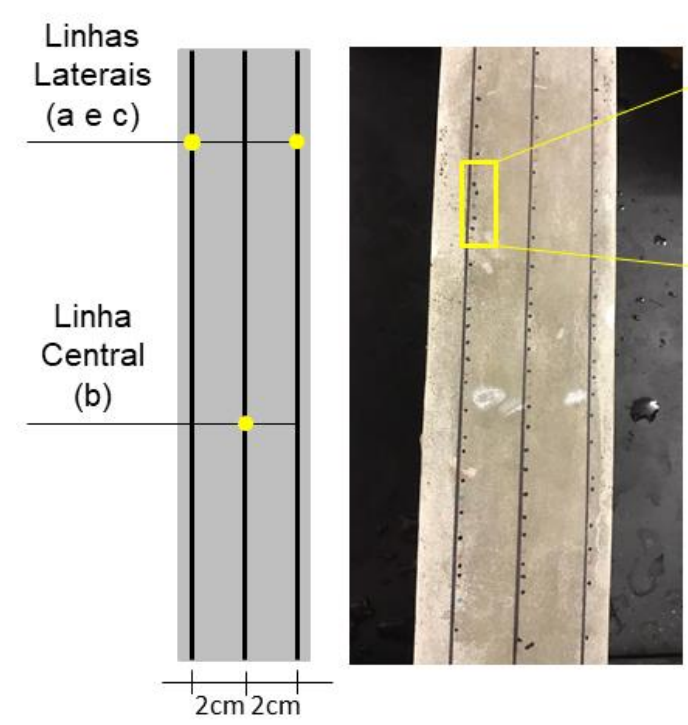

(b)

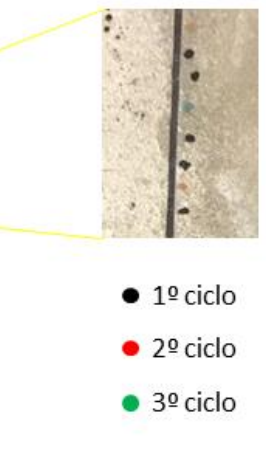

Figura 5-7 - (a) Localização dos eixos onde as fissuras foram observadas, dois laterais e um central, e (b) exemplo de uma amostra após 3 ciclos com detalhe da correspondência de cores com os ciclos.

Ao todo, para o ensaio cíclico, foram ensaiadas 12 amostras: três amostras para os dois níveis de deslocamento, $10 \mathrm{~mm}$ e $20 \mathrm{~mm}$, e para as duas condições, com e sem ciclos de molhagem. Cada amostra foi ensaiada quatro vezes, resultando em 48 ensaios.

\subsection{Resultados e discussões}

As curvas apresentadas nesta seção correspondem àquelas consideradas de comportamento típico. Nesta seção, será discutida a capacidade de autocicatrização dos compósitos reforçados com três camadas de tecido de curauá sob diferentes condições. Os valores notáveis, como resistência, rigidez, dentre 
outros apresentados, são a média aritmética das amostras ensaiadas. A exceção são os dados dos acompanhamentos das fissuras dos ensaios cíclicos que, foram tomados para uma amostra de cada condição e de cada nível de deslocamento. Os respectivos desvios padrão são apresentados.

Tanto para os ensaios cíclicos quanto para os ensaios com carregamento contínuo, foram calculados parâmetros como tenacidade e rigidez inicial. A tenacidade, grandeza relacionada à capacidade de absorção de energia, foi calculada como a área sob as curvas de força versus deslocamento. $\mathrm{O}$ ponto limite da área é aquele correspondente ao ponto de força máxima.

A rigidez inicial foi calculada como sendo o coeficiente angular da parte inicial da curva força versus deflexão aproximada por uma reta. A "parte inicial" para a pré-fissuração (ou do primeiro ciclo no caso dos ensaios cíclicos) corresponde à zona de comportamento linear-elástico do compósito. Já no carregamento até a ruptura (e para os demais ciclos no caso dos ensaios cíclicos), o limite da parte inicial é até o valor de deflexão correspondente à zona linear da pré-fissuração. A Figura 5-8 mostra a parte considerada para esse cálculo.

(a)
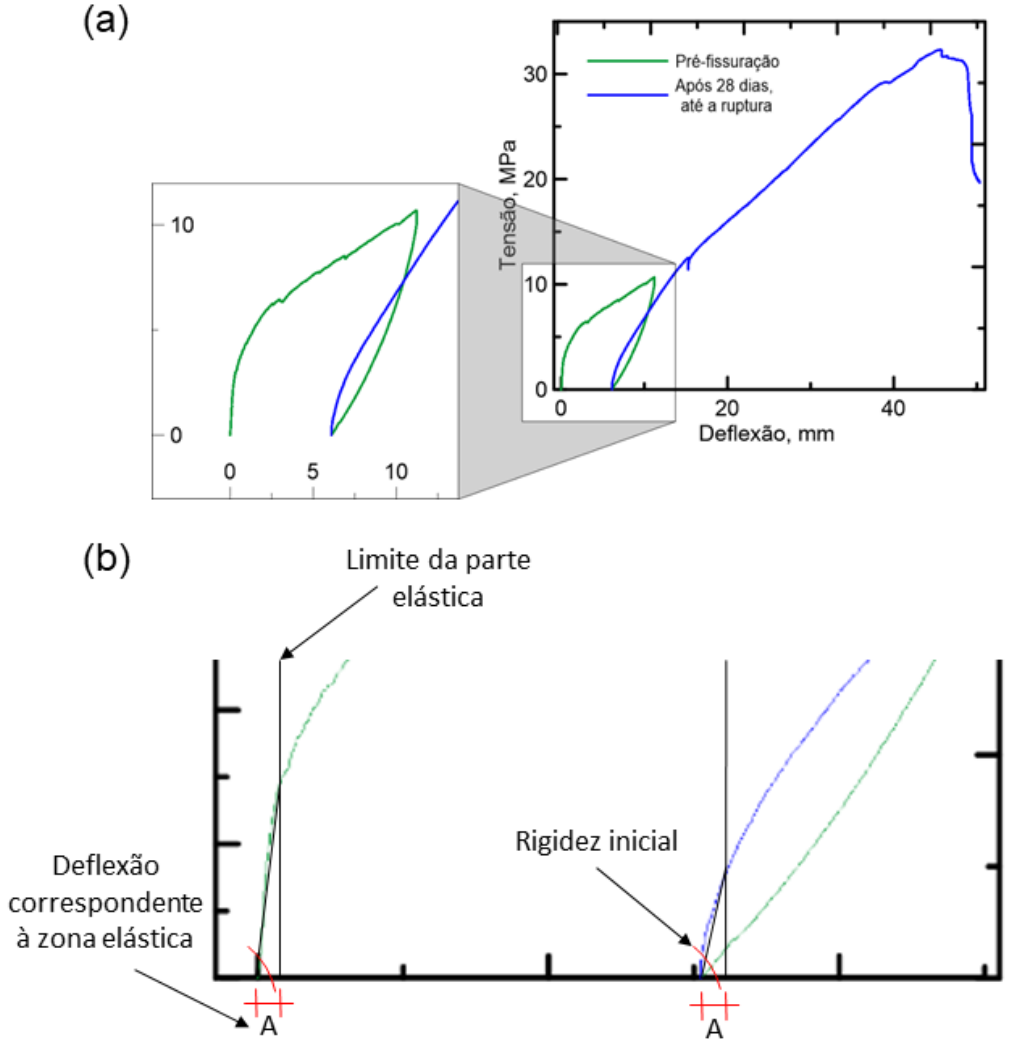

Figura 5-8 - Cálculo da rigidez inicial. (a) Parte do gráfico analisada; e (b) procedimento de cálculo. 


\subsubsection{Influência do carregamento contínuo durante 28 dias em compósitos pré-fissurados e sua capacidade de autocicatrização}

A pré-fissuração ao nível de $10 \mathrm{~mm}$ de deslocamento gerou fissuras de tamanho médio diferentes em cada posição do compósito. No geral, as fissuras que passaram pelas linhas laterais são de abertura média maior e em menor quantidade. Já a linha central apresenta maior número de fissuras com abertura média menor. Para o compósito submetido ao ambiente da sala com condições controladas $\left(\mathrm{T}=20^{\circ} \mathrm{C} \pm 2^{\circ} \mathrm{C}\right.$ e U.R. $\left.=55 \% \pm 5 \%\right)$ após a pré-fissuração, a abertura média das fissuras se encontra na Tabela 5-2, bem como a abertura máxima que passou por cada linha.

Tabela 5-2 - Número, média e abertura máxima das fissuras após a préfissuração, por linha

\begin{tabular}{c|c|c|c}
\hline $\begin{array}{c}\text { Posição } \\
\text { da linha }\end{array}$ & $\begin{array}{c}\text { Número de } \\
\text { fissuras }\end{array}$ & $\begin{array}{c}\text { Média do tamanho } \\
\text { das fissuras }(\mu \mathrm{m})\end{array}$ & $\begin{array}{c}\text { Tamanho } \\
\text { máximo }(\mu \mathrm{m})\end{array}$ \\
\hline Lateral 1 & 15 & 15 & 29 \\
Central & 21 & 8 & 16 \\
Lateral 2 & 14 & 13 & 23 \\
\hline
\end{tabular}

A média da abertura das fissuras foi considerada pequena o suficiente para ser propícia ao fechamento das mesmas. Segundo visto no item 2.3, fissuras menores do que $50 \mu \mathrm{m}$ podem ser cicatrizadas utilizando diversas estratégias em diferentes matrizes cimentícias.

A Figura 5-9 mostra as curvas de tensão versus deflexão da pré-fissuração e do carregamento até a ruptura dos compósitos após 28 dias sem carga contínua e com carga contínua, ambos os casos sem a presença de água. 


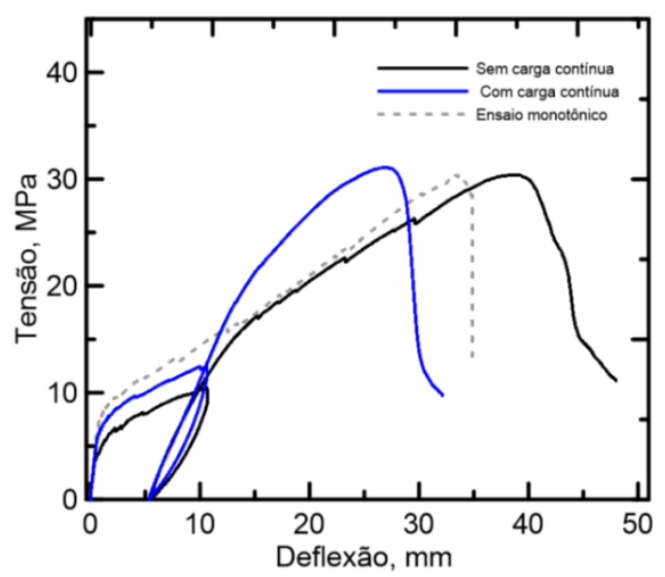

Figura 5-9- Pré-fissuração e comportamento dos compósitos após 28 dias sem e com carga contínua.

A partir das curvas apresentadas na Figura 5-9, é possível perceber que mesmo após 28 dias com carga contínua atuando como peso permanente, as amostras não demonstraram perda de resistência final. A rigidez inicial foi o parâmetro mais afetado: para as amostras sem carga, a queda da rigidez entre a pré-fissuração e o carregamento até a ruptura foi de $60,4 \%( \pm 7 \%)$. Já para as amostras submetidas ao carregamento constante essa perda foi de 70,6\% ( $\pm 6 \%)$. Uma diminuição na capacidade de deflexão da amostra com carga contínua é também observada. Esses parâmetros refletem na tenacidade que cai de 15,9 J $( \pm 7,5 \%)$ para $11,7 \mathrm{~J}( \pm 6,8 \%)$.

O comportamento da deflexão ao longo de 28 dias com carga para as amostras submetidas ao ciclo de água borrifada e não submetidas ao mesmo é mostrado na Figura 5-10.

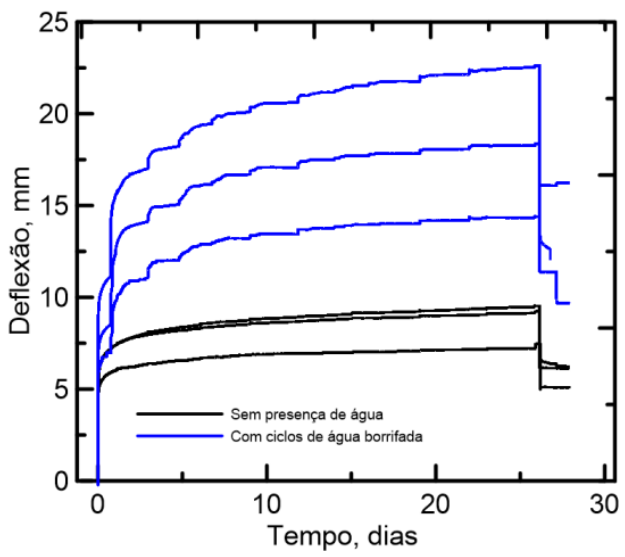

Figura 5-10 - Comportamento do deslocamento ao longo dos 28 dias das amostras submetidas ao carregamento contínuo, sem e com ciclos de água borrifada. 
As curvas das amostras submetidas ao ciclo de água borrifada (curvas azuis) se mostra menos uniforme, apresentando picos de deslocamento, do que as amostras que não receberam água (curvas pretas). Uma possibilidade é a de formação de novas fissuras e ampliação das já existentes, como constatado por Boschoff et al. [116]. A Figura 5-11 mostra exemplos de fissuras transversais que deram origem a novas fissuras, inclusive longitudinais, em amostras submetidas ao carregamento contínuo e aos ciclos de água borrifada.

(a)

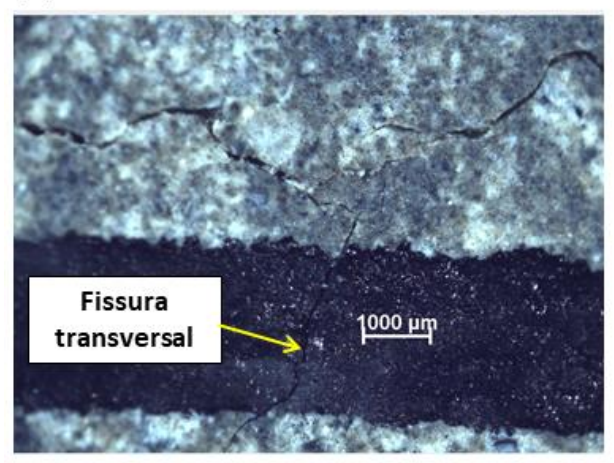

(c)

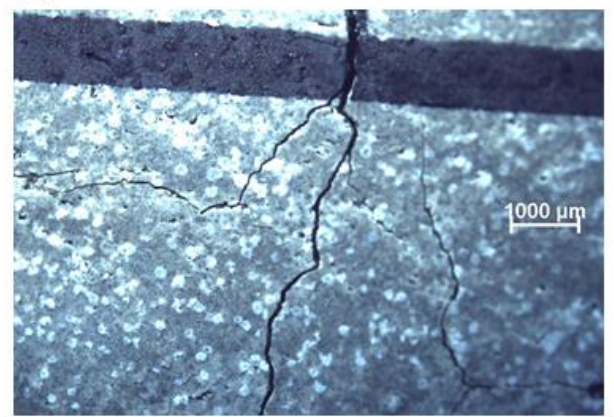

(b)

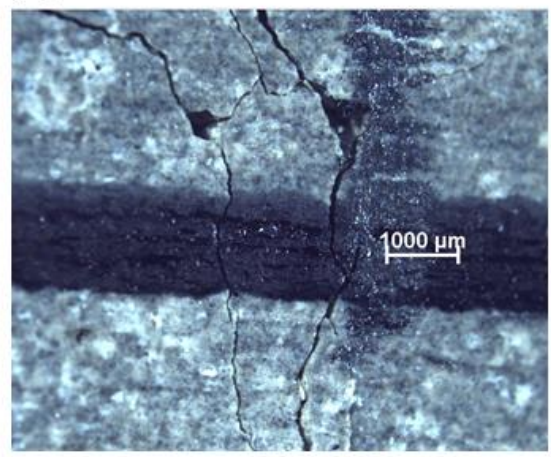

(d)

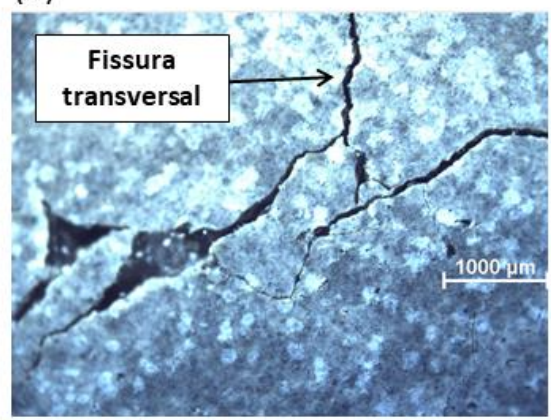

Figura 5-11 - Exemplo de como as fissuras de amostras submetidas ao carregamento contínuo se comportaram, se dividindo em outras fissuras.

A tendência das fissuras transversais se ramificarem em outras como mostrado na Figura 5-11 não foi observada em nenhuma outra amostra senão aquelas submetidas ao carregamento contínuo. A abertura de fissuras foi monitorada após a ruptura de amostras submetidas e não submetidas ao ciclo de água borrifada. Aquelas submetidas ao ciclo de água borrifada tiveram abertura média quase duas vezes maior do que as não submetidas, como mostra a Figura 512. 
(a)

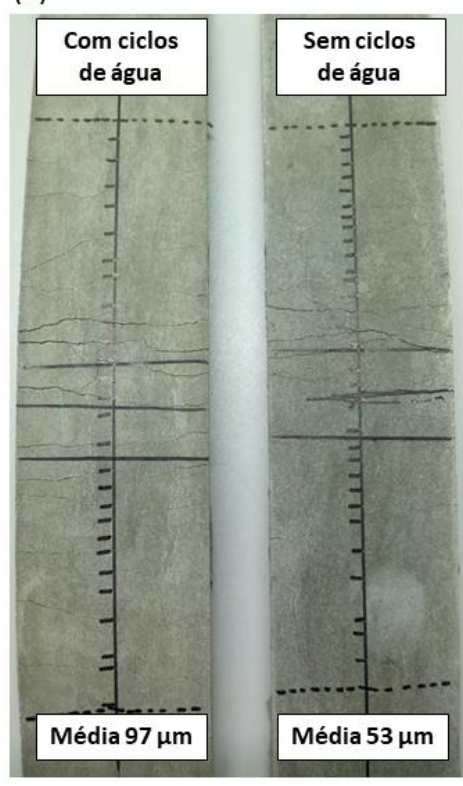

(b)

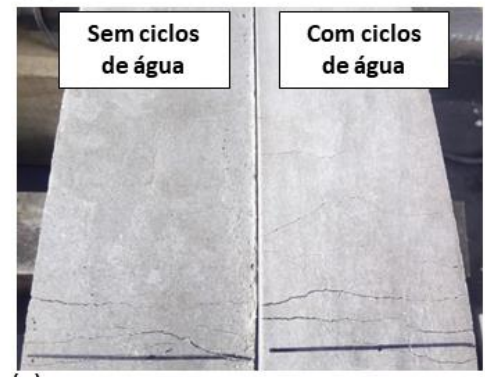

(c)

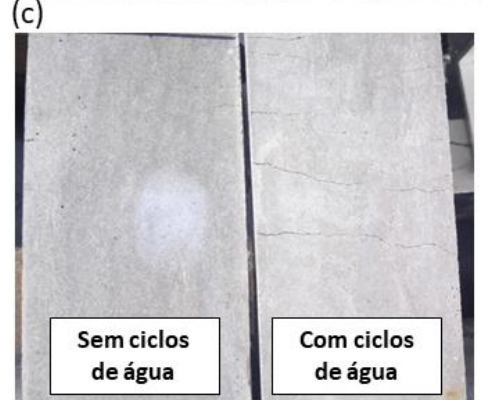

Figura 5-12 - Média da abertura das amostras submetidas aos cilos de água borrifada (97 m) e não submetidas aos ciclos (53 m); (b) detalhe superior das amostras; e (c) detalhe inferior das amostras, mostrando a diferença das aberturas das fissuras.

O deslocamento adicional é descrito como sendo aquele entre o momento após 6 horas $(0,25$ dias $)$ da aplicação de carga e o final do ensaio, como mostrado na Figura 5-13.

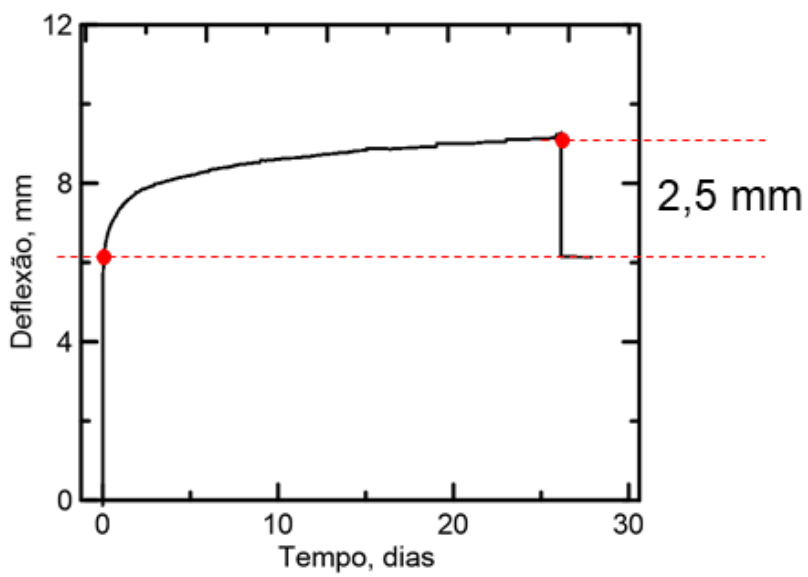

Figura 5-13 - Deflexão adicional recuperado após 28 dias sob carga conínua.

A média do deslocamento adicional foi de 2,5 $( \pm 0,5) \mathrm{mm}$ e correspondeu a $40 \%( \pm 5 \%)$ do deslocamento imediato (primeiras seis horas) para as amostras que não foram submetidas aos ciclos de água borrifada. Já para aquelas amostras que 
foram submetidas aos ciclos de água borrifada, a média do deslocamento adicional foi de $10,1( \pm 2,2) \mathrm{mm}$ e correspondeu a $122 \%( \pm 6 \%)$ do deslocamento imediato. É possível perceber que o deslocamento adicional é totalmente recuperado quando da retirada da carga.

A partir das imagens obtidas pelo estereoscópico portátil, foi observado que o deslocamento gerado pela carga contínua influenciou na abertura das fissuras. A Figura 5-14 mostra a mesma fissura em diferentes momentos: depois de dois dias (Figura 5-12 (a)) e depois de 27 dias (Figura 5-17 (b)) sob carga contínua.

(a)

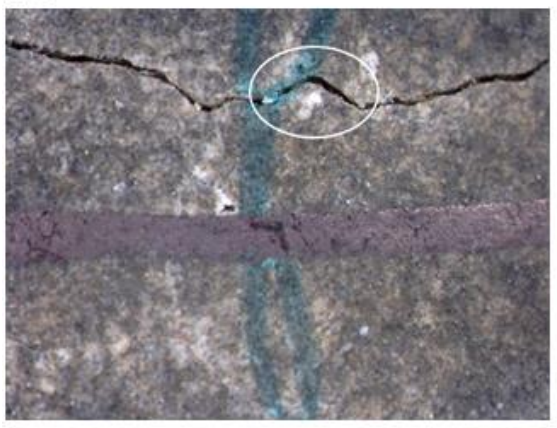

(b)

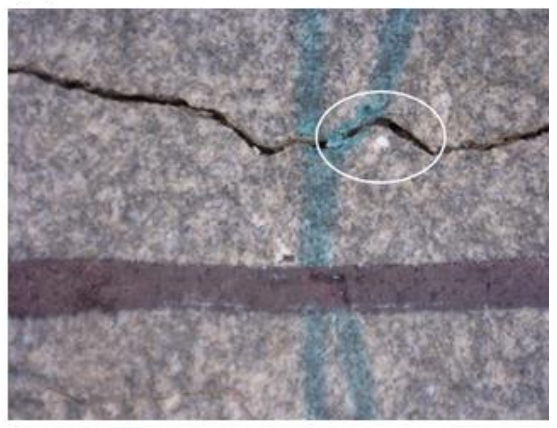

Figura 5-14 - Exemplo de fissura de amostra submetida ao ensaio de carga contínua após (a) 2 dias; e (b) 27 dias de carregamento.

A fissura mostrada é de uma amostra que não foi submetida aos ciclos de água borrifada e a parte analisada é aquela dentro do círculo branco. A mesma teve sua abertura aumentada em cerca de $10 \%$ de tamanho entre os 25 dias com carga contínua, resultando em uma abertura de $110 \mu \mathrm{m}$. Assim, o deslocamento adicional de $2,5 \mathrm{~mm}$ pode ser relacionado a esse aumento de abertura de $10 \%$. Já para as amostras expostas aos ciclos de água borrifada e com deslocamento adicional de 10,1 mm, entre o segundo e vigésimo sétimo dia de carregamento contínuo, as aberturas das fissuras aumentaram cerca de $35 \%$.

As amostras submetidas ao carregamento contínuo não apresentaram sinais de cicatrização na porção analisada, mesmo aquelas expostas aos ciclos de água borrifada.

Ao comparar o comportamento mecânico das amostras submetidas à carga contínua, com e sem água borrifada, não houve mudanças significativas, como mostrado pelas curvas na Figura 5-15. 


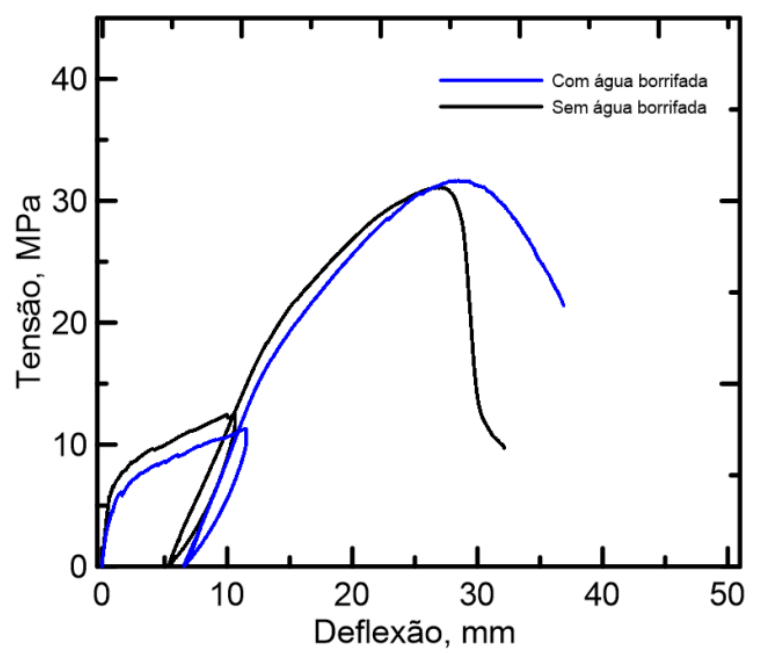

Figura 5-15 - Pré-fissuração e comportamento dos compósitos submetidos a carregamento contínuo submetidos e não submetidos aos ciclos de água borrifada.

Mesmo que amostras submetidas aos ciclos de água borrifada tenham apresentado maiores deformações adicional e final do que as sem presença de água, esse fato não interferiu no comportamento mecânico dos compósitos. A curva que representa o carregamento até a ruptura (Figura 5-15) de ambas as condições, com e sem ciclos de água borrifada, como mencionado, não apresentou disparidades entre si.

\subsubsection{Influência de diversas condições de exposição durante 28 dias em compósitos pré-fissurados}

A Figura 5-16 mostra as curvas de tensão versus deflexão das amostras sem carregamento contínuo, com e sem ciclos de água borrifada. As curvas de préfissuração ao nível de deslocamento de $10 \mathrm{~mm}$ também são mostradas. 


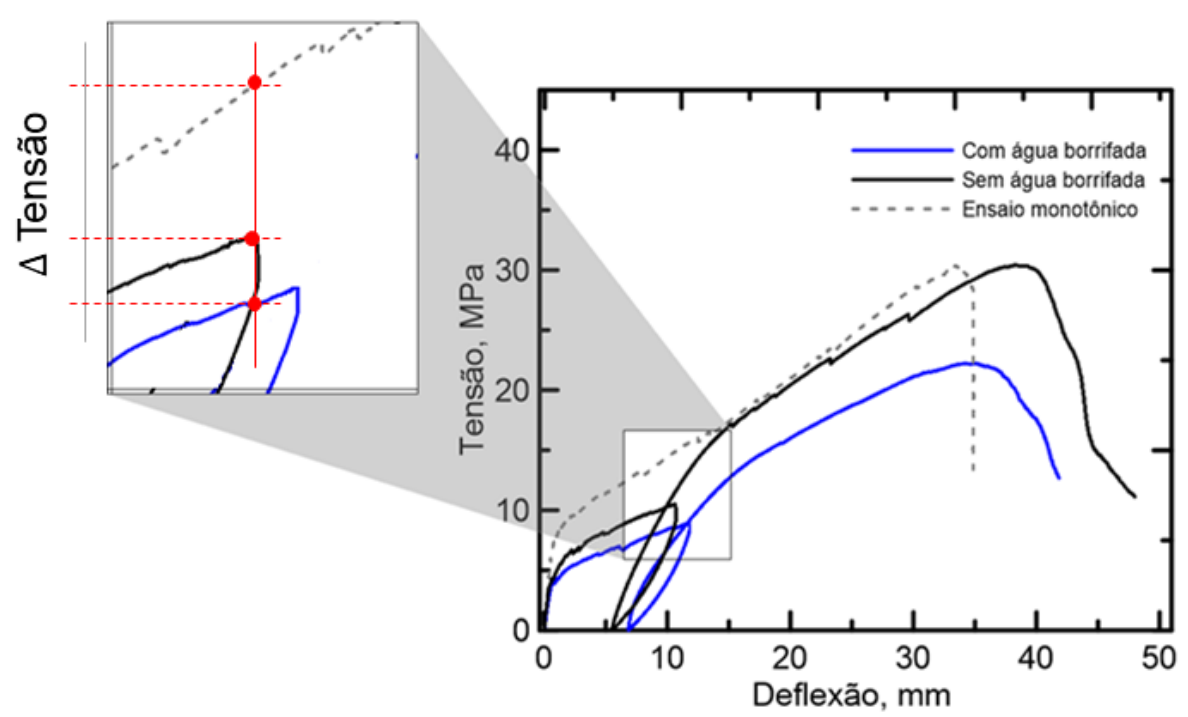

Figura 5-16 - Comparação entre as curvas dos compósitos que não foram submetidos à carga contínua. As amostras foram submetidas aos ciclos de água

borrifada ou não. A curva do ensaio monotônico também é apresentada

A tensão máxima teve variações significativas entre as amostras. Para as amostras submetidas apenas às condições controladas da sala $\left(\mathrm{T}=20^{\circ} \mathrm{C} \pm 2^{\circ} \mathrm{C}\right.$ e $\mathrm{UR}=55 \% \pm 5 \%$ ), a média da tensão máxima foi de $31,0 \mathrm{MPa}( \pm 3,9)$ e para aquelas submetidas aos ciclos de água borrifada foi de $20,9 \mathrm{MPa}( \pm 1,2)$. Ao analisar a curva correspondente à pré-fissuração (detalhe da Figura 5-10), percebe-se que, para um mesmo deslocamento, os valores de tensão diferem entre as amostras. Comparando a amostra submetida ao ensaio monotônico com aquela submetida ao ciclo de água borrifada, a variação do valor de tensão chega a 5,6 MPa, evidenciando a diferença de rigidez entre as amostras. Esta variação já ocorre na pré-fissuração, ou seja, antes das amostras serem expostas a qualquer condição. Isto é um indício de que a queda da tensão final, após a exposição aos ciclos de água borrifada, se dá por conta da variabilidade que os compósitos com fibras naturais sofrem. Este comportamento foi observado e ressaltado por Barros et al. [117]. Neste estudo, seis amostras foram fabricadas e ensaiadas da mesma maneira, mas tiveram dois grupos de respostas distintos. Os autores destacam que tal variabilidade é relacionada ao posicionamento da camada de fibra no compósito, ou seja, ao alinhamento do reforço, levando a diferentes valores de aderência entre matriz-fibra, influenciando no comportamento mecânico das amostras. 
Para as amostras submetidas às condições controladas da sala $\left(\mathrm{T}=20^{\circ} \mathrm{C} \pm\right.$ $2^{\circ} \mathrm{C}$ e UR=55\% $\pm 5 \%$ ) não houve cicatrização de fissuras. Já para as amostras submetidas aos ciclos de água borrifada, houve fechamento parcial de fissuras. As fissuras foram monitoradas após serem borrifadas 4 e 12 vezes. A Figura 5-17 mostra alguns exemplos de comportamento das fissuras após 4 ciclos de água borrifada.
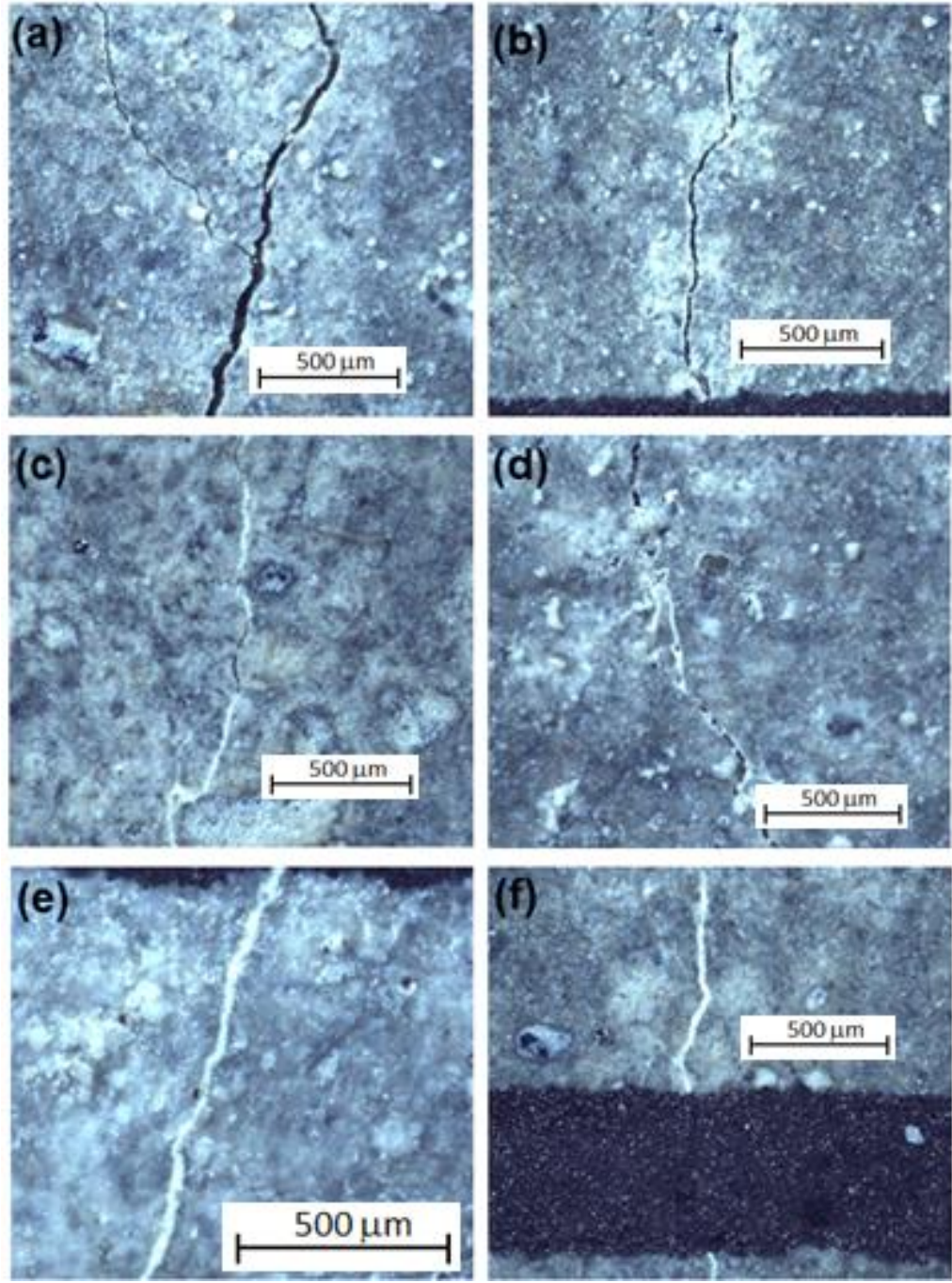

Figura 5-17 - Seis exemplos de comportamento das fissuras de uma mesma amostra após ser exposta a 4 ciclos de água borrifada; escala $500 \mu \mathrm{m}$.

Pode-se separar o comportamento das fissuras com relação à autocicatrização em três categorias:

i. Sem nenhum vestígio de cicatrização, como nos exemplos nas Figuras 5-17 (a) e (b), apesar da fissura na Figura 5-17 (b) ter uma parte mais esbranquiçada ao seu redor; 
ii. Parcialmente cicatrizada, como nos exemplos nas Figuras 5-17 (c) e (d), onde apenas partes das fissuras foram fechadas;

iii. Fissuras completamente cicatrizadas, como nos exemplos nas Figuras 5-17 (e) e (f).

A partir das Figuras 5-17 (a) e (b), percebe-se que o tamanho, neste caso, não foi determinante para a não cicatrização já que as fissuras apresentadas são de $40 \mu \mathrm{m}$ e de $18 \mu \mathrm{m}$, respectivamente. A própria fissura mostrada na Figura 5-17 (a) tem uma ramificação de $7 \mu \mathrm{m}$ também não cicatrizada.

O termo "fissuras completamente cicatrizadas" diz respeito às partes visíveis na tela do software, aproximadamente $1500 \mu \mathrm{m}$, pois foi a extensão avaliada em cada linha. De uma maneira geral, todas as fissuras monitoradas foram parcialmente fechadas se avaliadas em toda a sua extensão.

Após 12 ciclos de água borrifada, não se observou evolução na cicatrização das fissuras, se comparadas com aquelas expostas a 4 ciclos, como mostra a Figura 5-18.

(a)

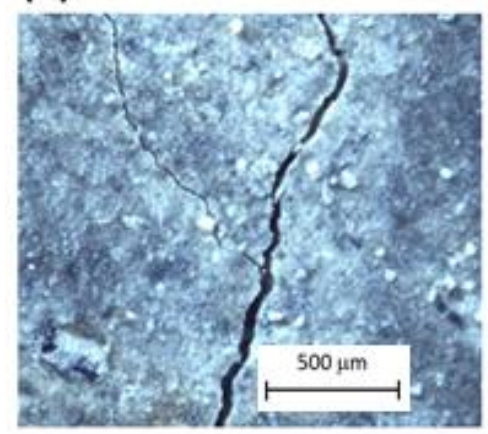

(c)

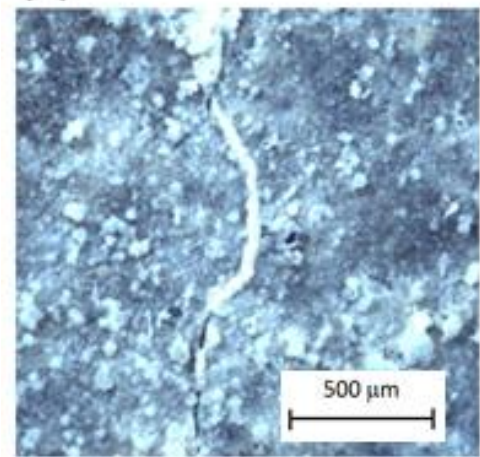

(b)

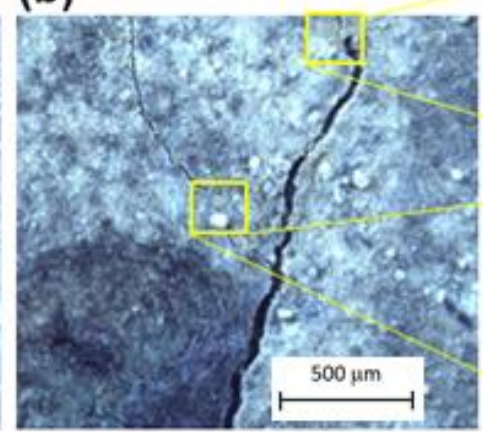

(d)

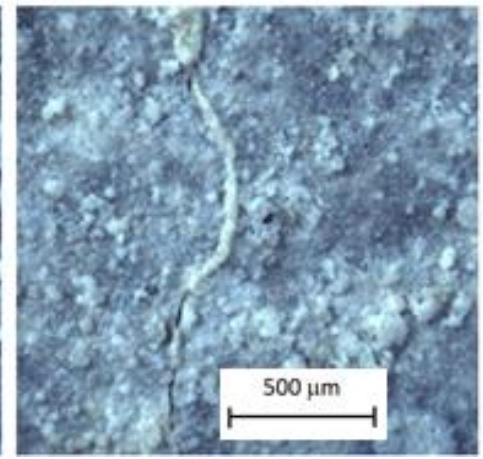

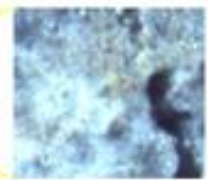

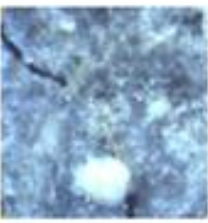

Figura 5-18 - Exemplos de duas fissuras após serem expostas a (a) e (c) 4 ciclos; e (b) e (d) 12 ciclos de água borrifada; detalhe de parte da fissura preenchida. 
As Figuras 5-18 (a) e (b) mostram uma mesma fissura após ser exposta a 4 e 12 ciclos de água borrifada, respectivamente. Não é observado nenhum avanço no fechamento das fissuras entre os ciclos, a não ser as pequenas partes realçadas nos detalhes em zoom (retângulos amarelos) na Figura 5-18 (b). Já na fissura parcialmente cicatrizada mostrada nas Figuras 5-18 (c) e (d), houve uma mudança na tonalidade do produto que preenche a mesma.

Para avaliar o efeito no comportamento mecânico e no fechamento das fissuras, o uso da água foi intensificado em outras amostras. A Figura 5-19 mostra a comparação entre as amostras submetidas ao ciclo de molhagem de 12 horas de imersão e imersão permanente com as amostras submetidas às condições controladas da sala. A pré-fissuração ao nível de deslocamento de $10 \mathrm{~mm}$ também é mostrada.

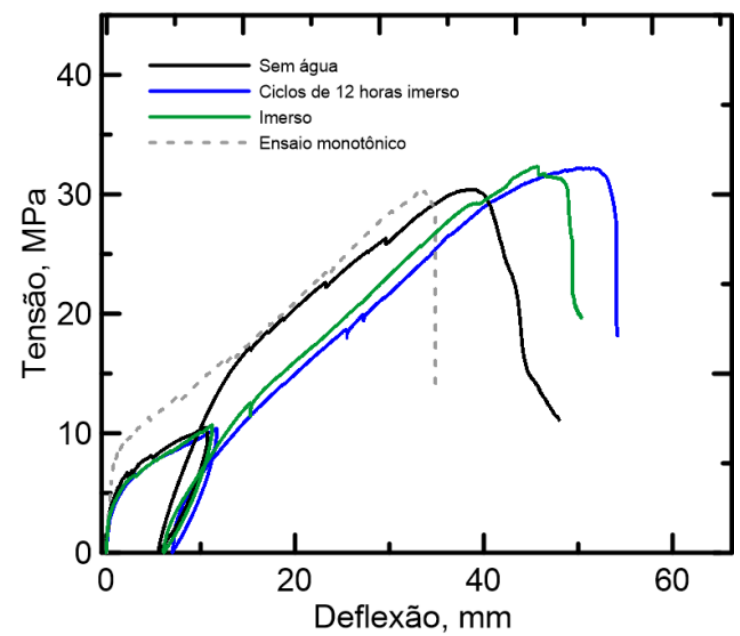

Figura 5-19 - Comparação entre amostras submetidas a ciclos de molhagem de 12 horas e imersas com amostra sem exposição a água.

A partir das curvas apresentadas na Figura 5-19 é possível concluir que a presença da água não modificou significativamente o comportamento mecânico dos compósitos. Os valores de tensão máxima foram bem próximos, bem como a capacidade de deflexão.

A amostra monitorada que foi submetida ao ciclo de imersão de 12 horas, teve todas as suas fissuras acompanhadas logo após o ensaio de pré-fissuração e após 1, 3, 6, 9, e 13 ciclos de molhagem. A evolução do fechamento de algumas fissuras após 1 e 13 ciclos de molhagem são mostradas a seguir na Figura 5-20 e comparadas com as amostras que não foram submetidas a imersão. 
(a)

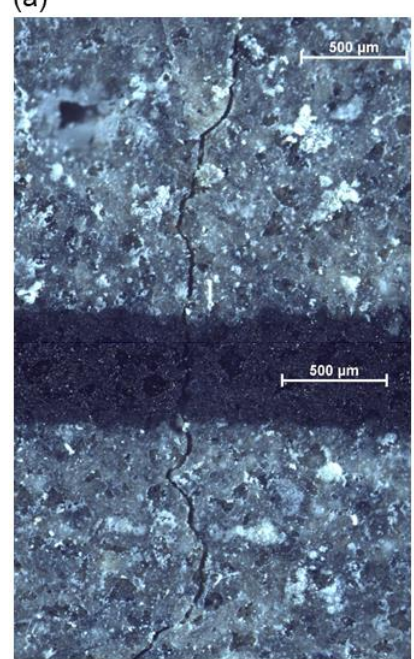

(b)

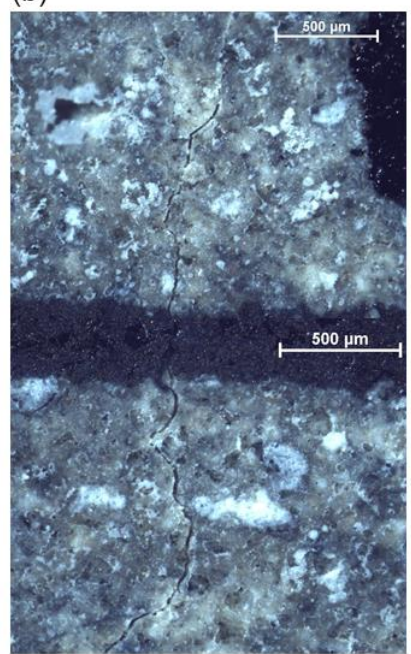

(c)

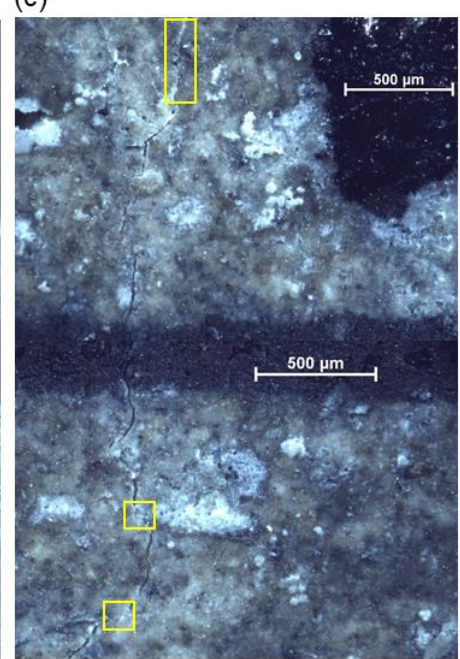

Figura 5-20 - Exemplo de uma fissura após (a) a pré-fissuração sem nenhum ciclo de molhagem; (b) 1 ciclo de molhagem e (c) 13 ciclos de molhagem com detalhes em amarelo das partes cicatrizadas.

A fissura mostrada na Figura 5-20 foi aquela que menos apresentou cicatrização das 15 fissuras analisadas nesta amostra. Foi também uma das maiores, com $22 \mu \mathrm{m}$. Mesmo assim, ela apresentou três partes cicatrizadas, realçadas pelos retângulos amarelos na Figura 5-20 (c). Ela apresentou também diminuição em seu tamanho, de $22 \mu \mathrm{m}$ para $12 \mu \mathrm{m}$ após 13 ciclos de molhagem.

(a)

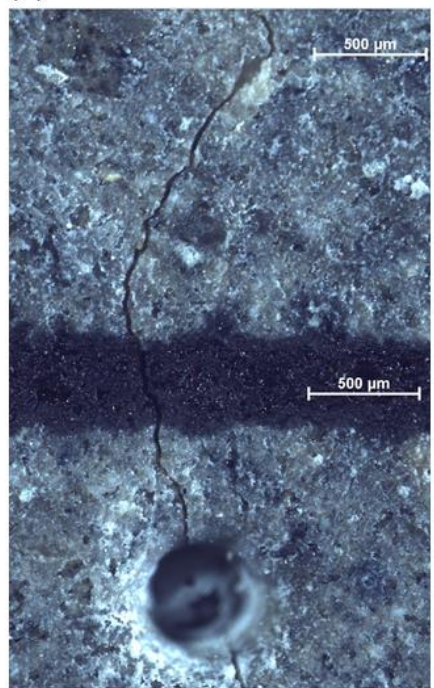

(b)

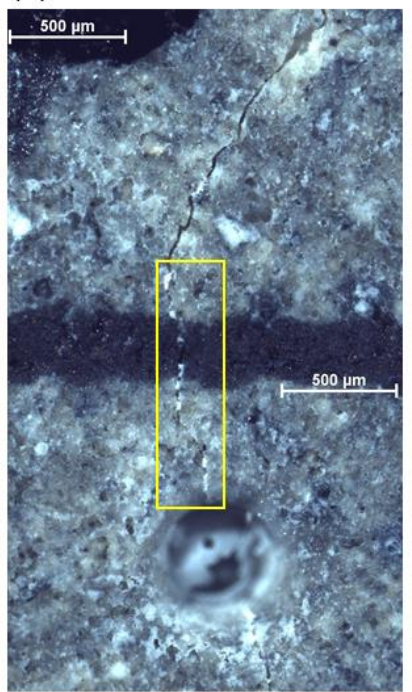

(c)

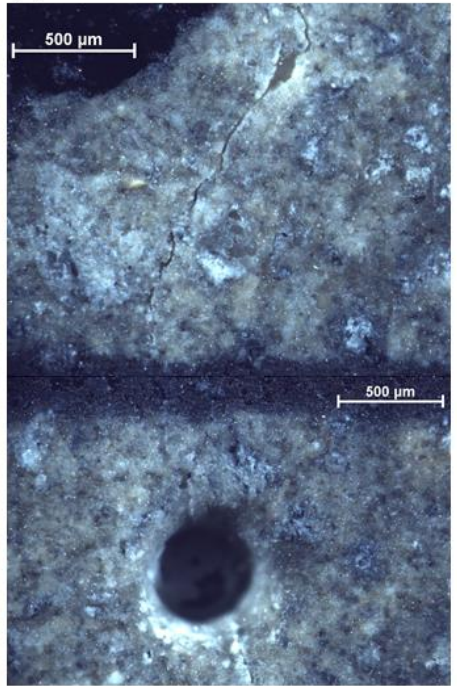

Figura 5-21 - Exemplo de uma fissura após (a) a pré-fissuração sem nenhum ciclo de molhagem; (b) 1 ciclo de molhagem e (c) 13 ciclos de molhagem. 
A fissura na Figura 5-21, de $19 \mu \mathrm{m}$, foi parcialmente cicatrizada após 13 ciclos de 12 horas de molhagem. A Figura 5-21 (b), dentro do retângulo amarelo, mostra o produto branco que preenche essa parte da fissura após 1 ciclo de molhagem. Este mesmo produto se mostra de coloração mais escura e mais integrada à matriz após 13 ciclos de molhagem (Figura 5-21 (c)).

(a)

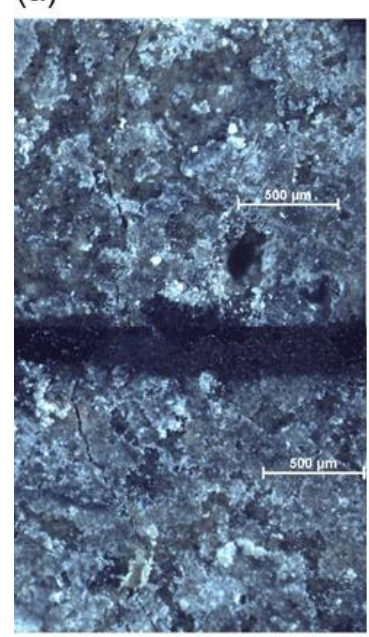

(b)

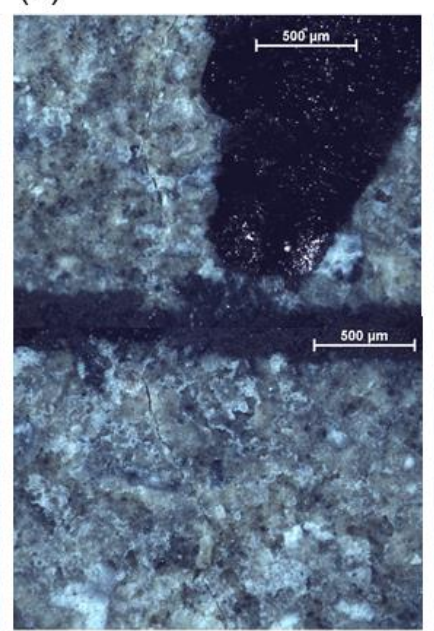

(c)

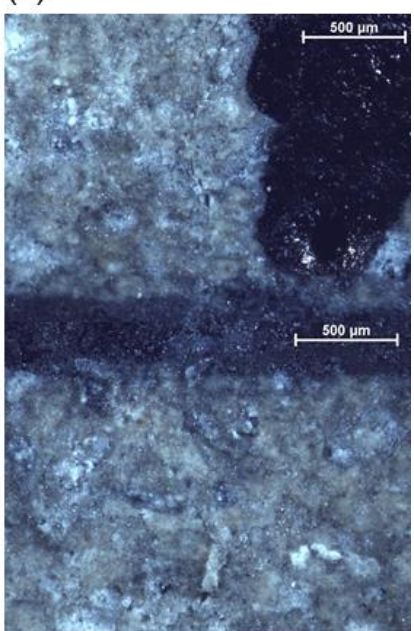

Figura 5-22 - Exemplo de uma fissura após (a) a pré-fissuração sem nenhum ciclo de molhagem; (b) 1 ciclo de molhagem e (c) 13 ciclos de molhagem.

A fissura na Figura 5-22, de $13 \mu \mathrm{m}$, foi completamente fechada na parte inferior e parcialmente fechada na parte superior após 13 ciclos de 12 horas de molhagem.

Para verificar o comportamento das fissuras internas ao compósito, lâminas delgadas foram analisadas. A Figura 5-23 mostra a micrografia de uma lâmina delgada (T1) sob luz polarizada simples, destacando uma microfissura. 
(a)

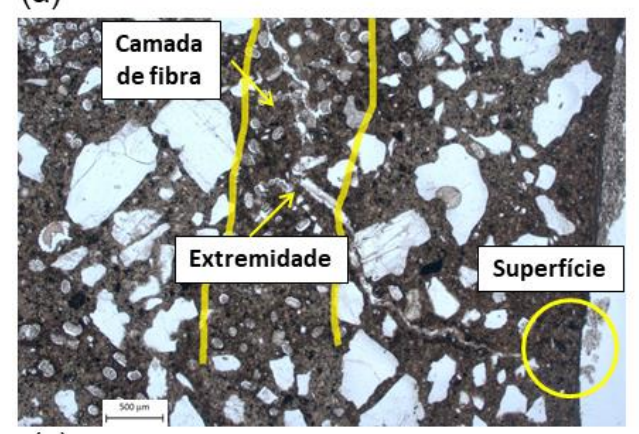

(c)

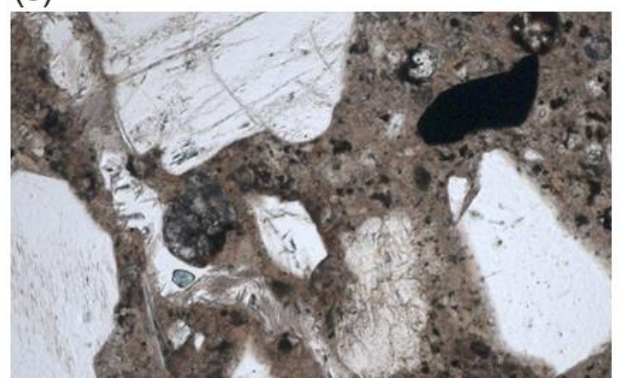

(b)

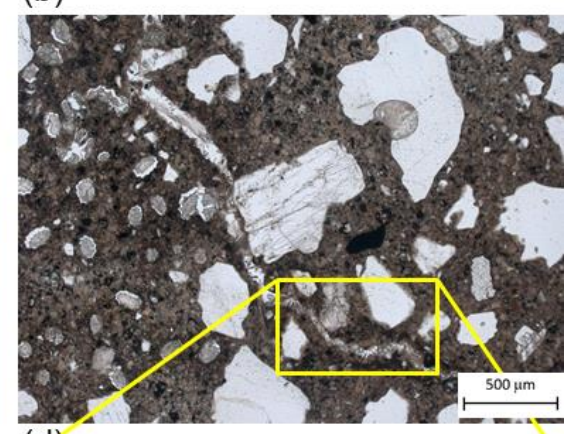

(d)

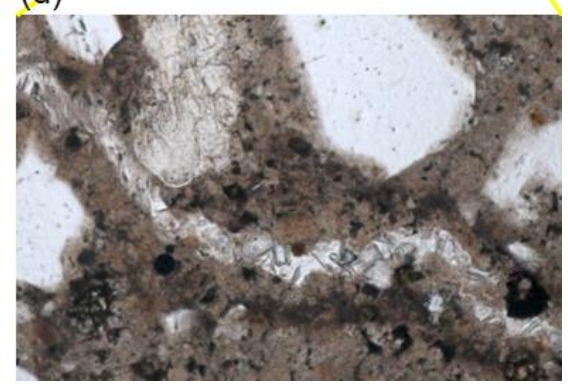

Figura 5-23 - Micrografias da lâmina delgada T1 sob luz polarizada simples (a) Localização da fissura; (b) extensão da fissura; (c) produto partindo das superfícies laterais; e (d) detalhe do produto.

A fissura mostrada na Figura 5-23 é interna, ou seja, ela não atingiu a superfície, não sendo possível sua visualização ao estereoscópico. A extremidade esquerda da fissura se encontra na região correspondente à camada de fibras, como mostrado na Figura 5-23 (a). Pode-se notar que a fissura está parcialmente preenchida (ver Figura 5-23 (d)) por produtos que partem das superfícies laterais, como no detalhe na Figura 5-23 (c). É possível observar que os produtos têm forma de cristais e de agulhas. Percebe-se também que a região da matriz próxima à fissura é de tom mais escuro do que a porção mais afastada.

As fibras naturais, por possuírem microestrutura porosa, são capazes de criar uma rede interna que pode transportar a umidade por dentro do compósito [14]. A Figura 5-24 mostra o detalhe da seção transversal da fibra que perdeu água por conta do processo para fabricação da lâmina delgada. A umidade transportada pode ser responsável pelas reações de hidratação tardia ao redor da camada de fibras, levando a formação de novos produtos. Esses novos produtos podem tanto preencher fissuras próximas, como pode ser no caso da fissura mostrada (Figura 5-23), quanto densificar a matriz na zona de interface, como sugerido pelo produto escuro ao redor da camada. Análises químicas, como Sistema de Energia 
Dispersiva (EDS - Energy Dispersive X-ray Detector), são necessárias para confirmar tais evidências.

Outras imagens das lâminas delgadas se encontram no Anexo A.

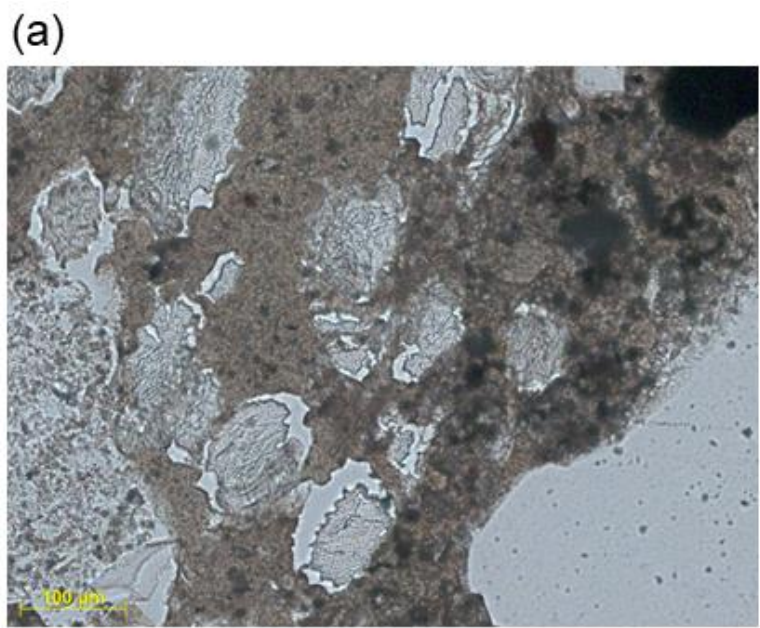

(b)

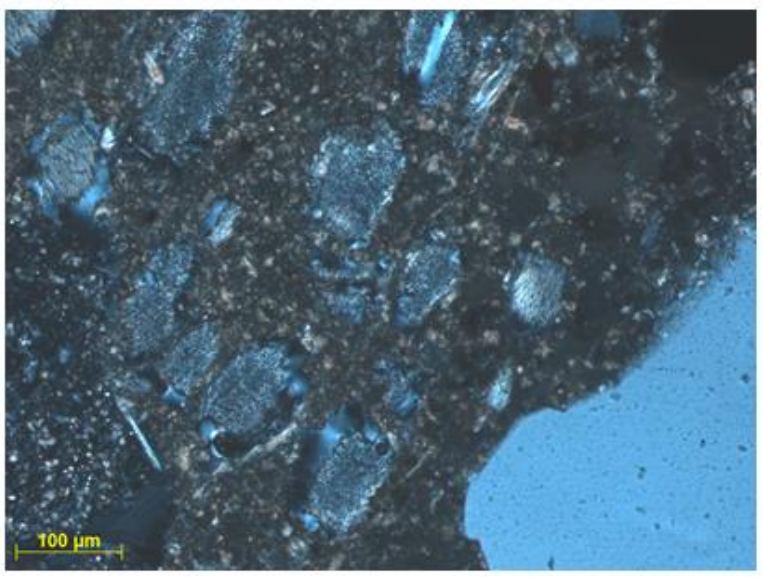

Figura 5-24 - Micrografias da seção transversal da amostra T1,

evidenciando as fibras encolhidas depois do processo de fabricação da lâmina delgada sob (a) luz polarizada simples e; (b) luz polarizada cruzada.

\subsubsection{Capacidade de autocicatrização do compósito reforçado com três camadas de tecido de curauá sob carregamento cíclico}

A Figura 5-23 mostra a resposta do comportamento do compósito reforçado com três camadas de tecido de curauá submetido ao ensaio cíclico, com níveis de deslocamento de $10 \mathrm{~mm}$ (Figura 5-23 (a)) e $20 \mathrm{~mm}$ (Figura 5-23 (b)) em cada ciclo, sem a presença de água. A curva representada pela linha pontilhada é a 
resposta de uma amostra submetida ao ensaio de flexão monotônico, para comparação.

(a)

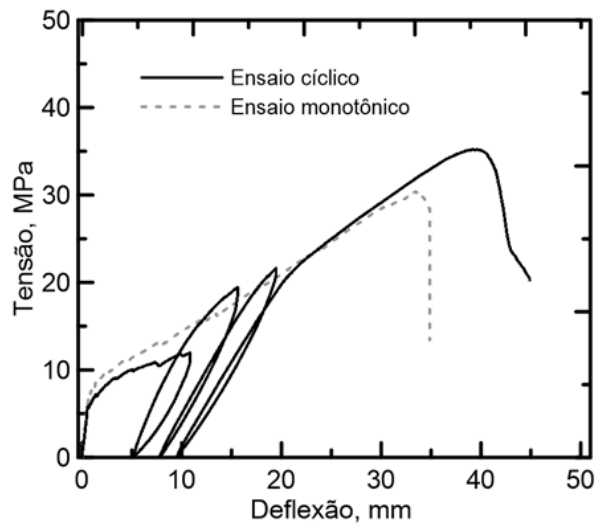

(b)

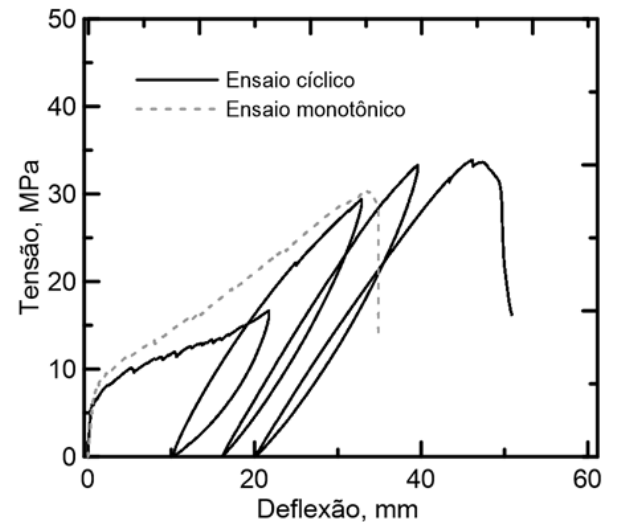

Figura 5-25 - Resposta do ensaio cíclico das amostras submetidas a nível de deslocamento de (a) $10 \mathrm{~mm}$ e (b) $20 \mathrm{~mm}$.

Valores médios de rigidez inicial, tensão máxima e tenacidade para cada ciclo se encontram na Tabela 5-3.

Tabela 5-3 - Resumo das propriedades mecânicas avaliadas a cada ciclo do ensaio cíclico das amostras submetidas a $10 \mathrm{~mm}$ e $20 \mathrm{~mm}$ de deslocamento, sem presença de água.

\begin{tabular}{|c|c|c|c|c|}
\hline \multicolumn{2}{|r|}{ Ciclo } & $\begin{array}{l}\text { Tensão Máxima } \\
(\mathrm{MPa})\end{array}$ & $\begin{array}{l}\text { Rigidez Inicial } \\
(\mathrm{N} / \mathrm{mm})\end{array}$ & $\begin{array}{c}\text { Tenacidade Fissurada } \\
(\mathrm{J})\end{array}$ \\
\hline \multirow{3}{*}{ 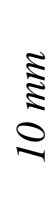 } & $1^{o}$ & $11,5 \pm 0,5(4,8 \%)$ & $217,4 \pm 11,7(11,5 \%)$ & $2,2 \pm 0,3(12,2 \%)$ \\
\hline & $2^{o}$ & $18,6 \pm 1,2(6,7 \%)$ & $101,1 \pm 11,7(11,5 \%)$ & $3,0 \pm 0,3(8,6 \%)$ \\
\hline & $3^{\circ}$ & $19,5 \pm 3,0(15,5 \%)$ & $63,6 \pm 5,5(8,7 \%)$ & $3,3 \pm 0,2(5,3 \%)$ \\
\hline \multirow{3}{*}{ 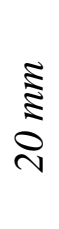 } & $1^{\mathrm{o}}$ & $17,7 \pm 0,9(5,2 \%)$ & $256,9 \pm 46,5(18,1 \%)$ & $5,8 \pm 0,3(0,5 \%)$ \\
\hline & $2^{o}$ & $33,5 \pm 0,3(0,9 \%)$ & $88,8 \pm 7,3(8,2 \%)$ & $11,3 \pm 1,0(8,9 \%)$ \\
\hline & $3^{\circ}$ & $33,5 \pm 3,2(9,6 \%)$ & $50,9 \pm 5,1(9,9 \%)$ & $12,0 \pm 0,6(4,9 \%)$ \\
\hline
\end{tabular}

Os ganhos da resistência máxima e da tenacidade em relação ao primeiro ciclo estão resumidos nas curvas da Figura 5-24. Os valores obtidos no primeiro ciclo são considerados $100 \%$. 
(a)

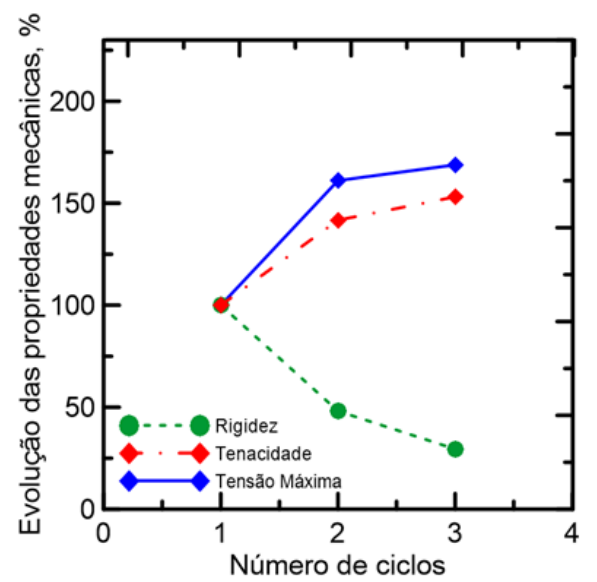

(b)

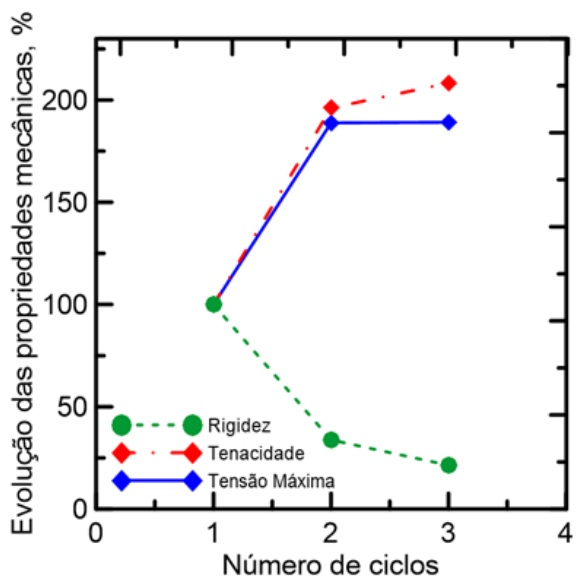

Figura 5-26 - Evolução das propriedades mecânicas a cada ciclo do ensaio cíclico das amostras submetidas a ambiente seco com (a) $10 \mathrm{~mm}$ e (b) $20 \mathrm{~mm}$ de nível de carregamento.

Após o primeiro ciclo de carregamento, pode-se perceber que a rigidez inicial diminuiu. Isso era esperado uma vez que a matriz já havia sido fissurada anteriormente e não houve fechamento das fissuras existentes para restaurar a matriz, como será visto adiante. Apesar disso, há um ganho de resistência após cada ciclo. Esse ganho é maior entre os ciclos 1 e 2. Pode-se atribuir esse ganho às reações de hidratação tardias da matriz, principalmente após os 28 dias, como visto no item 3.2.4 (Figura 3-4). A perda da rigidez foi compensada pelo ganho na resistência em termos de tenacidade. Percebe-se também que a tensão máxima do compósito submetido aos ciclos de carregamento supera a tensão máxima daquele que não foi submetido a nenhum carregamento prévio (linha tracejada da Figura 5-24).

Para as amostras que não foram expostas aos ciclos de água borrifada não foi visualmente observado nenhum tipo de cicatrização. A Figura 5-25 mostra uma mesma fissura ao longo dos ciclos de ensaio. A amostra foi submetida ao nível de deslocamento de $20 \mathrm{~mm}$. 
(a)

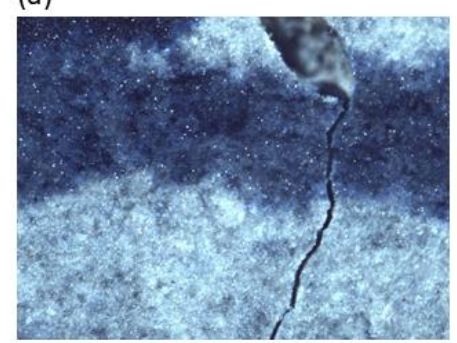

(b)

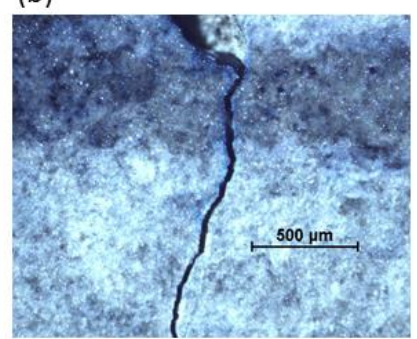

(c)

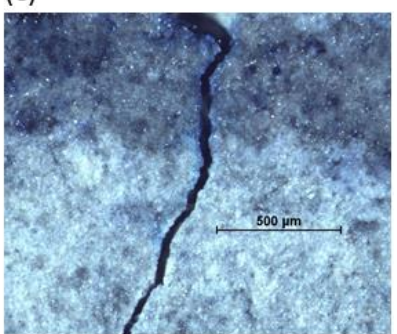

Figura 5-27- Evolução do comportamento de uma fissura de amostra submetida ao ensaio cíclico de nível de carregamento de $20 \mathrm{~mm}$ (a) após o primeiro ciclo; (b) após o segundo ciclo e (c) após o terceiro ciclo.

A fissura mostrada na Figura 5-25 corresponde a uma fissura presente da linha c, ou seja, na parte lateral do compósito. Ela teve seu tamanho aumentado de $22 \mu \mathrm{m}$ no primeiro ciclo para $31 \mu \mathrm{m}$ e $41 \mu \mathrm{m}$ no segundo e terceiro ciclos, respectivamente. A evolução dos tamanhos médio das fissuras das três linhas após cada ciclo de ensaio se encontra na Tabela 5-4 bem como os tamanhos máximos.

Tabela 5-4 - Média das aberturas das fissuras por ciclo de amostras submetidas aos ensaios cíclicos de nível de carregamento de $10 \mathrm{~mm}$ e $20 \mathrm{~mm}$, em $\mu \mathrm{m}$, por linha.

\begin{tabular}{|c|c|c|c|c|}
\hline & Linha & $1^{o}$ ciclo & $2^{\circ}$ ciclo & $3^{\circ}$ ciclo \\
\hline \multirow{4}{*}{ 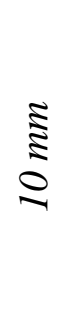 } & $\mathrm{a}$ & 10,3 & 12,7 & 15,0 \\
\hline & b & 8,6 & 10,1 & 11,5 \\
\hline & $\mathrm{c}$ & 10,9 & 12,7 & 13,5 \\
\hline & $\begin{array}{l}\text { Máxima } \\
\text { abertura }\end{array}$ & 19 & 23 & 26 \\
\hline \multirow{4}{*}{ 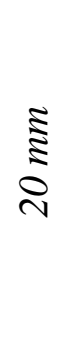 } & $\mathrm{a}$ & 18,2 & 22,7 & 23,5 \\
\hline & b & 17,2 & 20,7 & 21,7 \\
\hline & $\mathrm{c}$ & 16,7 & 22,6 & 28,7 \\
\hline & $\begin{array}{l}\text { Máxima } \\
\text { abertura }\end{array}$ & 38 & 55 & 55 \\
\hline
\end{tabular}

Assim como na Tabela 5-2, o tamanho médio das fissuras da linha central (b) é menor do que os das linhas laterais (a e c). Os valores de abertura máxima correspondem ao máximo de todas as linhas por ciclo. Tanto os valores médios 
quanto os valores máximos são quase duas vezes maiores para o nível de deslocamento de $20 \mathrm{~mm}$, comparando com o de $10 \mathrm{~mm}$.

Observando-se apenas os tamanhos das fissuras formadas no primeiro ciclo, nota-se que eles aumentam mais do que a média total, como mostrado na Tabela $5-5$.

Tabela 5-5 - Evolução da média das aberturas das fissuras formadas no primeiro ciclo dos ensaios cíclicos de nível de carregamento de $10 \mathrm{~mm}$ e $20 \mathrm{~mm}$, por linha.

\begin{tabular}{|c|c|c|c|}
\hline & Linha & $2^{\circ}$ ciclo & $3^{o}$ ciclo \\
\hline \multirow{3}{*}{ 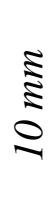 } & $\mathrm{a}$ & 12,1 & 16,7 \\
\hline & b & 13,5 & 13,8 \\
\hline & c & 15,0 & 16,8 \\
\hline \multirow{3}{*}{ 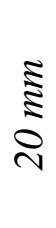 } & $\mathrm{a}$ & 28,3 & 31,7 \\
\hline & b & 24,2 & 25,8 \\
\hline & c & 24,8 & 30,9 \\
\hline
\end{tabular}

A média da abertura de todas as fissuras por ciclo se mantém com poucas variações (ver Tabela 5-4). Apesar abertura das fissuras existentes desde o primeiro ciclo (Tabela 5-5), o que mantém a média do valor dessa grandeza com aumento moderado é o surgimento de novas fissuras como mostrado nas curvas da Figura 5-26. As curvas referentes ao espaçamento (linhas vermelhas) entre fissuras são referentes às fissuras da linha central, linha b. 
(a)

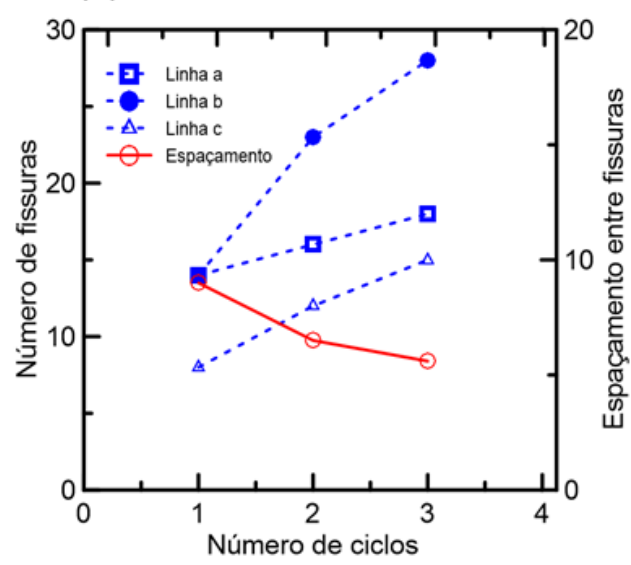

(b)

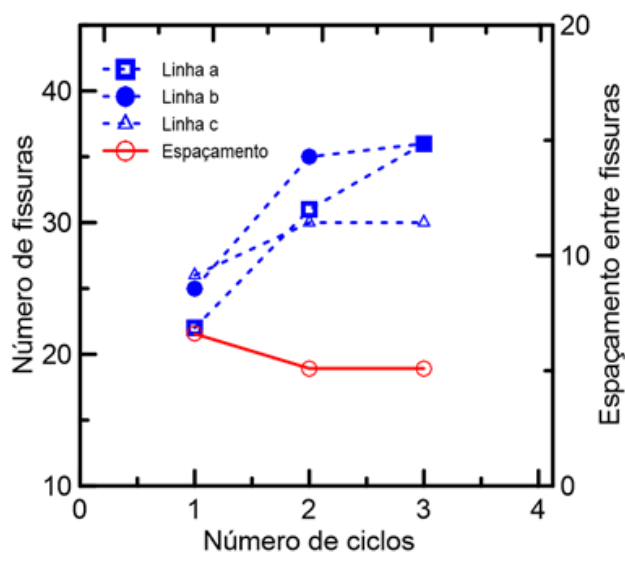

Figura 5-28 - Evolução do número de fissuras e espaçamento entre as mesmas de amostra submetida ao ensaio cíclico de nível de deslocamento de (a) $10 \mathrm{~mm}$ e (b) $20 \mathrm{~mm}$.

No ensaio cíclico com nível de deslocamento de 10 mm (Figura 5-26 (a)), o número de fissuras aumenta a cada ciclo (linhas tracejadas) enquanto o espaçamento entre fissuras diminui. Já para a amostra submetida ao nível de deslocamento de $20 \mathrm{~mm}$ (Figura 5-26 (b)), tanto o número de fissuras quanto o espaçamento entre elas se estabilizam a partir do segundo ciclo. Portanto, como mais fissuras são formadas enquanto o espaçamento entre elas não está saturado, a média do tamanho das fissuras para amostra do ensaio de $20 \mathrm{~mm}$ é superior ao de $10 \mathrm{~mm}$.

A Figura 5-27 mostra a resposta do comportamento dos compósitos submetidos aos carregamentos cíclicos, de 10 e $20 \mathrm{~mm}$, e aos ciclos de água borrifada. 
(a)

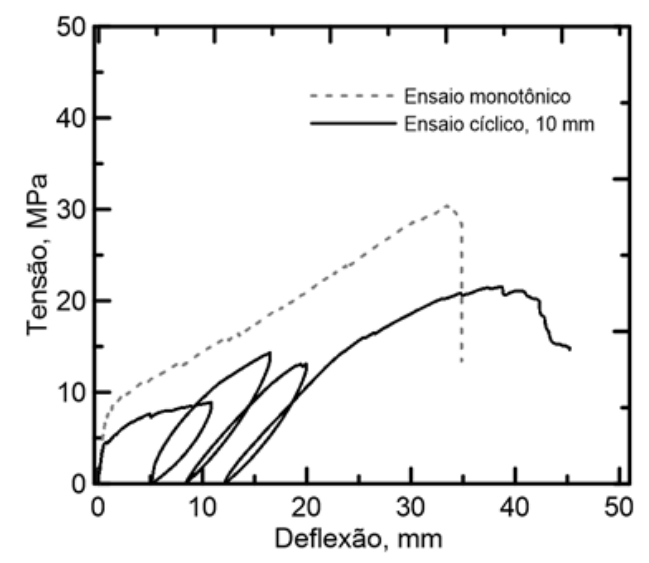

(b)

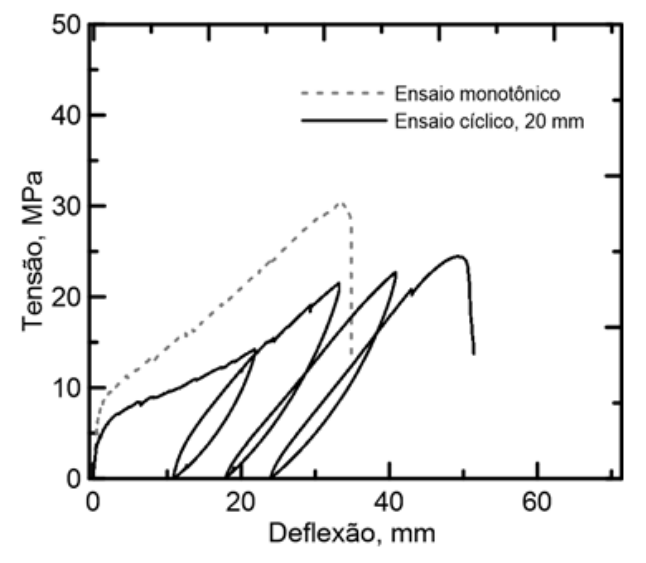

Figura 5-29 - Resposta ao carregamento cíclico dos compósitos submetidos a nível de deslocamento de (a) $10 \mathrm{~mm}$ e (b) $20 \mathrm{~mm}$, ambos submetidos ao ciclo de água borrifada.

O comportamento mecânico destas amostras foi similar ao das amostras não submetidas aos ciclos de água borrifada (Figura 5-23), porém com valores menores. Mais uma vez é observada a diferença entre os valores de tensão para um mesmo deslocamento do primeiro ciclo (quando a água ainda não tinha sido borrifada) e da amostra de referência. Assim como no ensaio de carga contínua, essa diferença foi atribuída às variações que os materiais compostos por fibras naturais estão sujeitos [117].

A Tabela 5-6 mostra valores médios de rigidez inicial, tensão máxima e tenacidade para cada ciclo deste ensaio. Os ganhos das propriedades mecânicas em relação ao primeiro ciclo estão resumidos nas curvas da Figura 5-28. Os valores obtidos no primeiro ciclo são considerados $100 \%$. 
Tabela 5-6 - Resumo das propriedades mecânicas avaliadas a cada ciclo do ensaio cíclico das amostras submetidas a $10 \mathrm{~mm}$ e $20 \mathrm{~mm}$ de deslocamento, com ciclos de água borrifada.

\begin{tabular}{|c|c|c|c|c|}
\hline \multicolumn{2}{|c|}{ Ciclo } & $\begin{array}{c}\text { Resistência } \\
\text { Máxima }(M P a)\end{array}$ & $\begin{array}{l}\text { Rigidez Inicial } \\
(\mathrm{GPa})\end{array}$ & $\begin{array}{c}\text { Tenacidade Fissurada } \\
(\mathrm{J})\end{array}$ \\
\hline \multirow{3}{*}{$\begin{array}{l}\mathfrak{\Xi} \\
\vdots\end{array}$} & $1^{\mathrm{o}}$ & $8,5 \pm 0,35(4,2 \%)$ & $\begin{array}{c}245,8 \pm 48,6 \\
(19,8 \%)\end{array}$ & $2,02 \pm 0,03(1,3 \%)$ \\
\hline & $2^{\circ}$ & $13,3 \pm 0,93(7,0 \%)$ & $\begin{array}{l}127,8 \pm 27,5 \\
(21,5 \%)\end{array}$ & $2,56 \pm 0,05(2,0 \%)$ \\
\hline & $3^{\circ}$ & $12,8 \pm 0,58(4,6 \%)$ & $53,9 \pm 4,4(8,1 \%)$ & $2,14 \pm 0,01(0,3 \%)$ \\
\hline \multirow{3}{*}{ 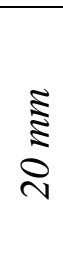 } & $1^{o}$ & $14,6 \pm 1,7(11,7 \%)$ & $\begin{array}{c}218,6 \pm 37,2 \\
(17,0 \%)\end{array}$ & $6,18 \pm 0,90(14,5 \%)$ \\
\hline & $2^{\circ}$ & $23,1 \pm 1,9(8,3 \%)$ & $\begin{array}{c}109,7 \pm 16,0 \\
(14,6 \%)\end{array}$ & $8,47 \pm 1,16(13,8 \%)$ \\
\hline & $3^{\circ}$ & $22,5 \pm 1,0(4,4 \%)$ & $55,9 \pm 7,9(14,1 \%)$ & $8,14 \pm 1,07(13,1 \%)$ \\
\hline
\end{tabular}

(a)

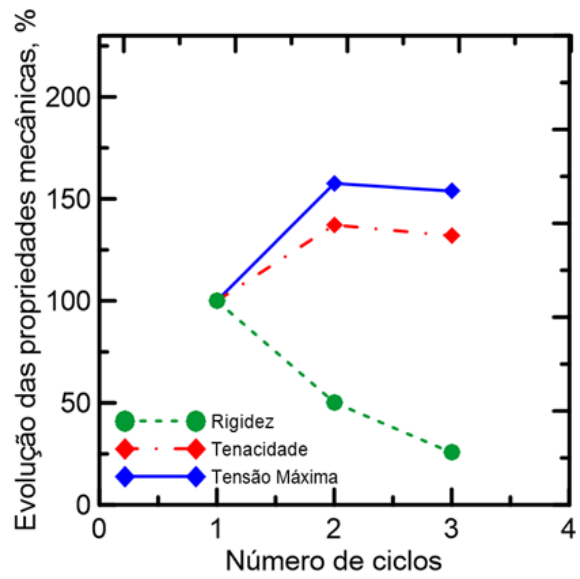

(b)

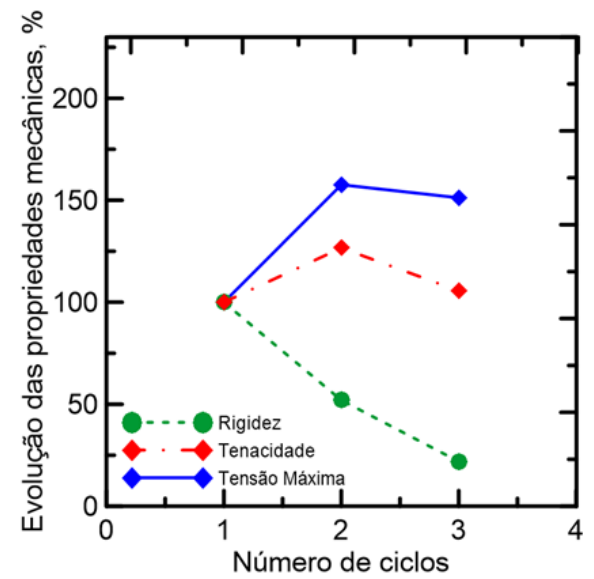

Figura 5-30 - Evolução das propriedades mecânicas a cada ciclo do ensaio cíclico das amostras submetidas a ciclos de água borrifada com (a) $10 \mathrm{~mm}$ e (b) 20 mm de nível de carregamento.

Assim como no ensaio de carga contínua, a rigidez diminuiu após o primeiro ciclo, por conta das fissuras formadas e não recuperadas no período de exposição à água. A perda dessa rigidez inicial foi semelhante entre os diferentes níveis de carregamento. Já a tenacidade e a tensão máxima aumentaram, principalmente entre o primeiro e segundo ciclos, assim como ocorreu com as amostras sem a presença de água. O que difere as amostras submetidas a ciclos de água borrifada das amostras sem a presença de água são os valores do terceiro 
ciclo que não apresentaram ganhos em relação ao segundo ciclo. Apesar disso, os valores permaneceram mais altos do que o do primeiro ciclo.

As Figuras 5-29 e 5-30 mostram o comportamento de duas fissuras ao longo dos ciclos, cuja amostra foi submetida ao ensaio de nível de deslocamento de 10 $\mathrm{mm}$.

(a)

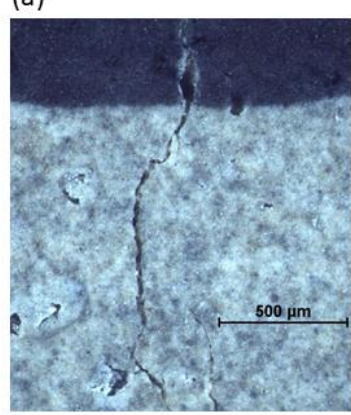

(b)

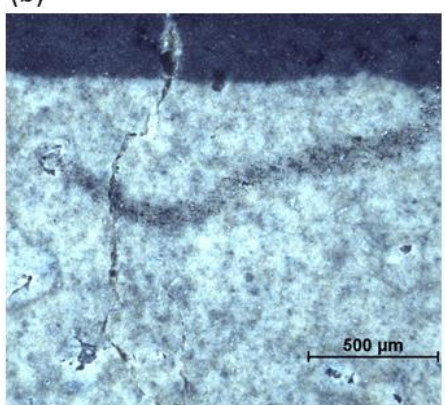

(c)

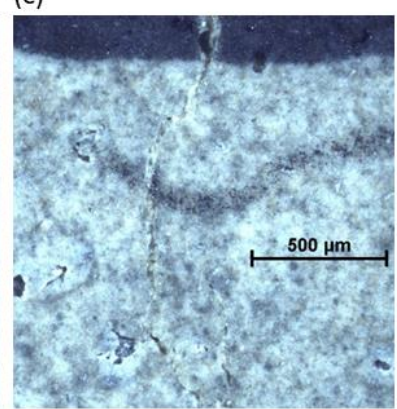

Figura 5-31 - Evolução do comportamento da fissura de $19 \mu$ m (a) após o primeiro ciclo e após 12 ciclos de água borrifada; (b) após o segundo ciclo e 25 ciclos de água borrifada e (c) após o terceiro ciclo e após 37 ciclos de água borrifada.

Percebe-se que mesmo após dois ensaios, o produto que preenche a fissura na Figura 5-27 (b) foi capaz de resistir a mais um carregamento e ainda se consolidar, fechando a fissura. Já na fissura mostrada na Figura 5-32, apesar da fissura se cicatrizar aos poucos ao longo dos ciclos, uma parte dela é alargada para $85 \mu \mathrm{m}$. Mesmo com o tamanho maior do que a média das fissuras estudadas, é possível perceber no detalhe do retângulo amarelo na Figura 5-30 (c) que boa parte dessa abertura é preenchida.

(a)

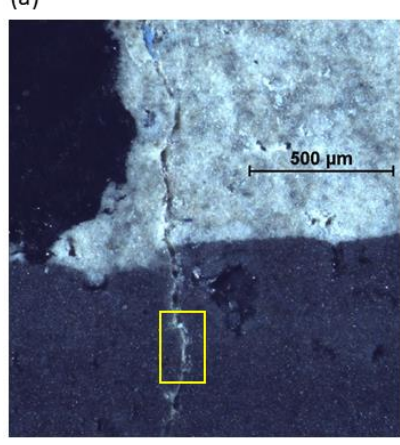

(b)

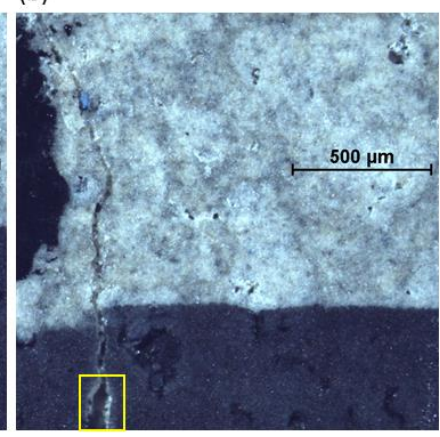

(c)

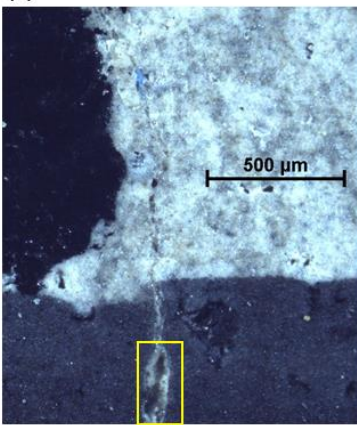

Figura 5-32 - Evolução do comportamento da fissura de $25 \mu \mathrm{m}$ (a) após o primeiro ciclo e após 12 ciclos de água borrifada; (b) após o segundo ciclo e 25 ciclos de água borrifada e (c) após o terceiro ciclo e após 37 ciclos de água borrifada. 
A Figura 5-33 mostra um exemplo de fissura cujo produto que a preenche não foi capaz de resistir ao terceiro ciclo de ensaio. As Figuras 5-31 (d) e (e) são a continuação dessa fissura para mostrar que isto acontece com toda a extensão onde estava o produto.
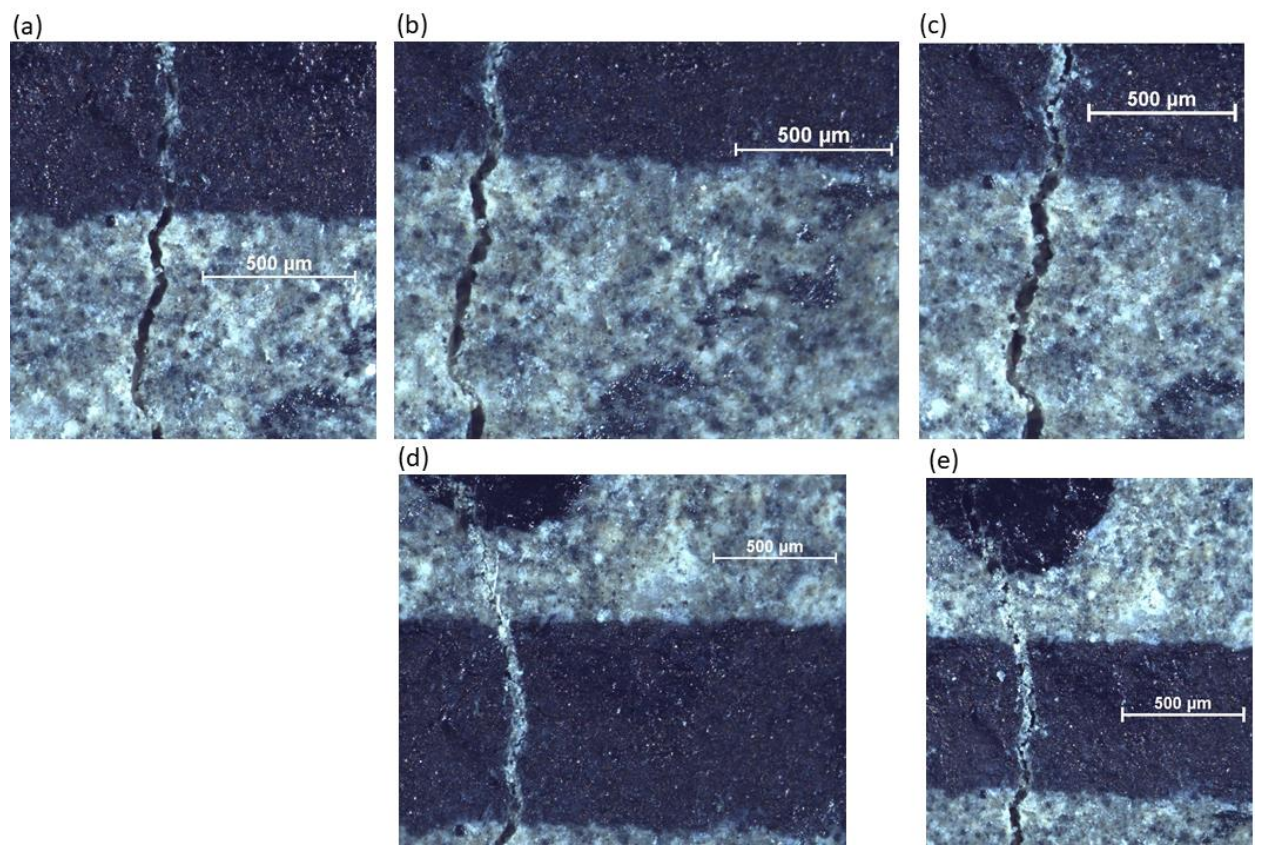

Figura 5-33 - Evolução do comportamento da fissura de $44 \mu \mathrm{m}$ (a) após o primeiro ciclo e após 12 ciclos de água borrifada; (b) após o segundo ciclo e 25

ciclos de água borrifada; (c) após o terceiro ciclo e após 37 ciclos de água borrifada; (d) continuação da mesma fissura após o segundo ciclo e 25 ciclos de água borrifada e (e) continuação da mesma fissura logo antes do terceiro ciclo e após 37 ciclos de água borrifada.

\subsection{Conclusões}

Neste Capítulo a capacidade de autocicatrização do compósito reforçado com três camadas de tecido unidirecional de curauá foi avaliada por meios de ensaios mecânicos e acompanhamento do comportamento das fissuras.

Após 28 dias submetidas ao carregamento contínuo, as amostras não perderam a capacidade de resistência, atingindo valores de tensão similares aos das amostras de referência. Porém, a diminuição na rigidez inicial e na capacidade de deflexão gerou uma perda na tenacidade de $25 \%$. As fissuras de amostras submetidas ao carregamento contínuo não apresentam cicatrização, somente um 
aumento na abertura de $10 \%$ e $35 \%$, relacionados a deslocamentos adicionais de 2,5 $\mathrm{mm}$ e $10,1 \mathrm{~mm}$, respectivamente.

As fissuras formadas no estágio de pré-fissuração ao nível de deslocamento de $10 \mathrm{~mm}$ apresentaram tamanho médio de $12 \mu \mathrm{m}$. As amostras pré-fissuradas e expostas a ciclos de água borrifada por 28 dias tiveram suas fissuras parcialmente ou totalmente fechadas. O uso intensificado da água (ciclos de molhagem de 12 horas e imersão total) não mudou significativamente o comportamento mecânico das amostras. Amostras em ambiente sem a presença de água não apresentaram cicatrização de suas fissuras.

A resistência máxima, rigidez inicial e tenacidade foram calculadas após cada ciclo do ensaio cíclico, para os dois níveis de carregamento, $10 \mathrm{~mm}$ e 20 $\mathrm{mm}$. As amostras apresentaram perda de rigidez inicial, porém aumento na resistência máxima, fazendo com que a tenacidade fissurada se tornasse maior após cada ciclo. O maior ganho foi verificado no segundo ciclo, sendo atribuído às reações de hidratação tardias, principalmente após os 28 dias.

Com o passar dos ciclos, mais fissuras foram formadas, mantendo a abertura média estreita $(15$ e $25 \mu \mathrm{m}$, para níveis de deslocamento de 10 e $20 \mathrm{~mm}$, respectivamente). Como já observado, amostras em ambiente sem presença de água não apresentaram cicatrização de suas fissuras. Para aquelas expostas aos ciclos de água borrifada, as fissuras foram parcialmente ou totalmente fechadas. Em alguns casos, o produto que preencheu as fissuras suportou três ciclos de deslocamento. 


\section{Conclusões e trabalhos futuros}

\subsection{Conclusões}

As fibras de curauá longas e alinhadas em uma só direção se mostraram eficientes como reforço de diferentes compósitos cimentícios, com valores de resistência comparáveis a outros compósitos com tecidos distintos, inclusive sintéticos. Os compósitos estudados apresentaram comportamento strain/deflection hardening, com formação de múltiplas fissuras de média de abertura que não excederam $43 \mu \mathrm{m}$ e $60 \mu \mathrm{m}$ na tração e na flexão, respectivamente. A partir do comportamento dos compósitos e do padrão de fissuração desenvolvido, foi possível concluir que as fibras de curauá possuem resistência e aderência adequada para reforçar compósitos cimentícios. Os compósitos alcançaram altos valores de resistência, até $14,7( \pm 1,2)$ e $28,0( \pm 2,0)$ MPa nos ensaios de tração e flexão, respectivamente. Análises feitas a partir de campos de deformação gerados por DIC se mostraram eficientes tanto para acompanhamento da evolução da formação das fissuras quanto para estimativa da abertura média das fissuras durante o ensaio.

A autocicatrização foi estudada a partir de ensaios mecânicos e acompanhamento visual das fissuras. A partir de ensaios de carregamento contínuo, percebeu-se que a capacidade de resistência não foi alterada, mesmo as amostras carregadas por 28 dias. Porém, houve perda de tenacidade, de cerca de $25 \%$, ao comparar amostras com e sem carregamento contínuo. Não houve cicatrização nas fissuras das amostras que foram submetidas ao carregamento contínuo, mesmo aquelas expostas aos ciclos de água borrifada. Houve somente um aumento na abertura das fissuras de até $35 \%$.

A presença da água em diferentes quantidades em amostras pré-fissuradas não afetou significativamente o desempenho mecânico dos compósitos. Para as amostras submetidas ao ciclo de molhagem de 12 horas, apenas um ciclo foi suficiente para haver autocicatrização parcial ou total das fissuras. 
A partir dos ensaios cíclicos, foi possível observar ganhos mecânicos se comparado com amostras sem pré-fissuração, mesmo após três ciclos de carregamento. Houve queda na rigidez inicial, porém houve ganho na resistência máxima a cada ciclo, contribuindo para o aumento da tenacidade. Em condição sem presença de água não houve cicatrização das fissuras superficiais e isso não impediu o reganho das propriedades mecânicas observadas. Assim, a evolução dessas propriedades não é atribuída ao fechamento das fissuras e sim a reações de hidratação tardia. Já na presença de água, de uma maneira geral, houve fechamento parcial e total de fissuras. Alguns produtos que preencheram as fissuras permaneceram íntegros até o terceiro ciclo de ensaio mecânico.

\subsection{Sugestões para trabalhos futuros}

Algumas sugestões são dadas a seguir a fim de melhor justificar e fundamentar os efeitos não conclusivos deste trabalho como, por exemplo:

- Ensaio de tração do tecido da fibra de curauá;

- Verificar a distribuição das fibras nas camadas do compósito reforçado com cinco camadas ao longo da espessura.

- Tratamentos nas fibras para aumentar a aderência entre fibra-matriz;

- Ensaios de arrancamento, tanto de um filamento quanto do tecido utilizado;

- Modelagem dos compósitos desenvolvidos para fins de previsão de comportamento e comparação com campos gerados pelo DIC;

- Análises químicas para caracterização dos produtos que preenchem as fissuras. 


\section{Referências bibliográficas}

[1] ACI 544. State-of-the-Art Report on Fiber Reinforced Concrete 2002;1R-96.

[2] METHA PK, MONTEIRO PJM. Concrete: microstructure, properties and materials. McGraw-Hill; doi:http://dx.doi.org/10.1036/0071462899.

[3] FAIRBAIRN EMR, AMERICANO BB, CORDEIRO GC, PAULA TP, FILHO RDT, SILVOSO MM. Cement replacement by sugar cane bagasse ash : CO 2 emissions reduction and potential for carbon credits. Environment Manage 2010; 91:1864-71. doi: 10.1016/ j.jenvman. 2010.04.008

[4] ARDANUY M, CLARAMUNT J, DIAS R, FILHO T. Cellulosic fiber reinforced cement-based composites : A review of recent research. Construction and Building Materials 2015;79: 115-28. doi: 10.1016 /j.conbuildmat.2015.01.035.

[5] TONOLI GHD, SANTOS SF, JR HS, DELVASTO S, GUTIÉRREZ RM DE, LOPEZ MM, et al. Effects of natural weathering on microstructure and mineral composition of cementitious roofing tiles reinforced with fique fibre. Cem Concr Composites 2011; 33:225-32. doi: 10.1016 /j.cemconcomp.2010.10.013.

[6] YAN L, KASAL B, HUANG L. A review of recent research on the use of cellulosic fi bres, their fibre fabric reinforced cementitious, geopolymer and polymer composites in civil engineering. Composites Part B 2016;92:94-132. doi:10.1016/j.compositesb.2016.02.002.

[7] JUAREZ CA, FAJARDO G, MONROY S, DURAN-HERRERA A, VALDEZ P, MAGNIONT C. Comparative study between natural and PVA fibers to reduce plastic shrinkage cracking in cement-based composite. Construction and Building Materials 2015; 91:164-70. doi:10.1016/j.conbuildmat.2015.05.028.

[8] BENTCHIKOU M, GUIDOUM A, SCRIVENER K, SILHADI K, HANINI S. Effect of recycled cellulose fibres on the properties of 
lightweight cement composite matrix. Construction and Building Materials 2012;34:451-6. doi:10.1016/j.conbuildmat.2012.02.097.

[9] SILVA F DE A, MOBASHER B, FILHO RDT. Cracking mechanisms in durable sisal fiber reinforced cement composites. Cement and Concrete Composites 2009;31:721-30. doi:10.1016/j.cemconcomp.2009.07.004.

[10] WEI J, MEYER C. Degradation mechanisms of natural fiber in the matrix of cement composites. Cement Concrete Research 2015;73:1-16. doi:http://dx.doi.org/10.1016/j.cemconres.2015.02.019.

[11] KOMURAIAH A, KUMAR NS, PRASAD BD. Chemical Composition of Natural Fibers and its Influence on Their Mechanical Properties. Mechanics Composite Materials 2014;50:359-76.

[12] AGOPYAN V, JR. HS, JOHN VM, CINCOTTO MA. Developments on vegetable fibre - cement based materials in São Paulo, Brazil : an overview. Cement Concrete Composite 2005; 27:527-36. doi: 10.1016/j.cemconcomp.2004.09.004.

[13] HEARN N. Self-sealing, autogenous healing and continued hydration : What is the difference? Material Structure 1998;31:563-7.

[14] FERRARA L, FERREIRA SR, KRELANI V, SILVA F, FILHO RDT. Effect of natural fibres on the self-healing capacity of high performance fibre reinforced cementitious. 3rd Int. RILEM Conf. Strain Hardening Cementitious Composites., 2014, p. 9-16.

[15] MOHANTY AK, MISRA M, HINRICHSEN G. Biofibres, biodegradable polymers and biocomposites: An overview. Macromol Materials Engineering 2000;276:1-24.

[16] LIN S, CALVAR IL, CATCHMARK JM, LIU J, DEMIRCI A, CHENG K. Biosynthesis, production and applications of bacterial cellulose. Cellulose 2013;20:2191-219. doi:10.1007/s10570-013-9994-3.

[17] PANDEY JK, NAGARAJAN V, MOHANTY AK, MISRA M. Commercial potential and competitiveness of natural fiber composites. Fourteenth. Elsevier Ltd.; 2015. doi:10.1016/B978-1-78242-373-7.000019.

[18] KICINSKA- JAKUBOWSKA A, BOGACZ E, ZIMINIEWSKA M. Review of Natural Fibers . Part I - Vegetable Fibers. Journal of Natural Fibers 2012;9:150-67. doi:10.1080/15440478.2012.703370. 
[19] MOBASHER B. Mechanics of fiber and textile reinforced cement composites. 2012.

[20] SOUZA SF, FERREIRA M, SAIN M, FERREIRA MZ, PUPO HF, CHERIAN BM, et al. The use of curaua fibers as reinforcements in composites 2015:700-20. doi:10.1533/9781782421276.5.700.

[21] Projekt Curauá 2010. http://icatu-goodwood.com/site/Projekt_Curaua.html (último acesso em 5 de fevereiro de 2017).

[22] ZAH R, HISCHIER R, LEÃO AL, BRAUN I. Curauá fibers in the automobile industry - a sustainability assessment. J Clean Prod 2007;15:1032-40. doi:10.1016/j.jclepro.2006.05.036.

[23] TOMCZAK F, SATYANARAYANA KG, SYDENSTRICKER THD. Studies on lignocellulosic fibers of Brazil : Part III - Morphology and properties of Brazilian curauá fibers. Composites Part A Appl Sci Manuf 2007;38:2227-36. doi:10.1016/j.compositesa.2007.06.005.

[24] JAY A, SANTOS PA DOS, GIRIOLLI JC, MORAES G. The curauá challenge : optimizing natural fibres. Plast Addit Compd 2009:12-6. doi:10.1016/S1464-391X(09)70134-5.

[25] AZWA ZN, YOUSIF BF, MANALO AC, KARUNASENA W. A review on the degradability of polymeric composites base on natural fibres. Materials Design 2013;47:424-42. doi:10.1016/j.matdes.2012.11.025.

[26] ZIMMERMANN T, PÖHLER E, GEIGER T. Cellulose Fibrils for Polymer Reinforcement. Adv Eng Mater 2004:754-61. doi: 10.1002 /adem.200400097.

[27] JOHN MJ, THOMAS S. Biofibres and biocomposites. Carbohydrate Polymers 2008;71:343-64. doi:10.1016/j.carbpol.2007.05.040.

[28] JAWAID M, KHALIL HPSA. Cellulosic / synthetic fibre reinforced polymer hybrid composites : A review. Carbohydr Polym 2011;86:1-18. doi:10.1016/j.carbpol.2011.04.043.

[29] YAN L, CHOUW N, JAYARAMAN K. Flax fibre and its composites A review. Composites Part B 2014; 56:296-317. doi: 10.1016/ j.compositesb.2013.08.014.

[30] WONG KJ, YOUSIF BF, LOW KO. The effects of alkali treatment on the interfacial adhesion of bamboo fibres. Materials Design Applicatios 2010;224:139-48. doi:10.1243/14644207JMDA304. 
[31] DITTENBER DB, GANGARAO HVS. Critical review of recent publications on use of natural composites in infrastructure. Composites Part A 2012;43:1419-29. doi:10.1016/j.compositesa.2011.11.019.

[32] NETA LSL, COSTELLA ÂM DOS S, FILHO J DE AM, GIACON VM. Caracterização físico-química de fibras de curauá e sua aplicação em compósitos poliméricos. Sci Amazon 2015; 4:21-7. doi: 10.19178/ Sci.Amazon.v4i1.21-27.

[33] CARASCHI JC, LEÃO AL. Characterization of Curaua Fiber. Mol Cryst Liq Cryst Science Technology 2000; 353:149-52. doi: 10.1080/ 10587250008025655.

[34] SOUZA SF, LEÃO AL, CAI JH, WU C, SAIN M, CHERIAN BM. Nanocellulose from Curava Fibers and their Nanocomposites. Mol Cryst Liq Cryst 2010;522:342-52. doi:10.1080/15421401003722955.

[35] NETRAVALI AN, CHABBA S. Composites get greener. Materials Today 2003:22-9.

[36] METHACANON P, WEERAWATSOPHON U, SUMRANSIN N, PRAHSARN C, BERGADO DT. Properties and potential application of the selected natural fibers as limited life geotextiles. Carbohydr Polym 2010;82:1090-6. doi:10.1016/j.carbpol.2010.06.036.

[37] STAMBOULIS A, BAILLIE CA, PEIJS T. Effects of environmental conditions on mechanical and physical properties of flax fibers. Composites Part A Appl Sci Manuf 2001;32:1105-15.

[38] BOS HL, VAN DEN OEVER MJA, PETERS OCJJ. Tensile and compressive properties of flax fibres for natural fiber reinforced composites. J Mater Sci 2002;37:1683-92.

[39] BALEY C. Analysis of the flax fibres tensile behaviour and analysis of the tensile stiffness increase. Composites Part A Appl Sci Manuf 2002;33:939-48.

[40] SPINACÉ MAS, LAMBERT CS, FERMOSELLI KKG, PAOLI M DE. Characterization of lignocellulosic curaua fibres. Carbohydr Polymer 2009;77:47-53. doi:10.1016/j.carbpol.2008.12.005.

[41] FIDELIS MEA, PEREIRA TVC, GOMES O DA FM, SILVA F DE A, FILHO RDT. The effect of fiber morphology on the tensile strength of natural fibers. Materials Research Technology 2013;2:149-57. 
doi:10.1016/j.jmrt.2013.02.003.

[42] PIMENTEL MG, BORGES JP DAS C, SOUZA PM DE, GHAVAMI K. Resposta à flexão e análise de tenacidade de argamassas reforçadas com fibra de Curauá. Revista Matéria 2016:18-26.

[43] LOPES FFM, ARAÚJO GT, LUNA S, NASCIMENTO JWB, SILVA VR. Modificação das propriedades das fibras de curauá por acetilação. Revista Bras Eng Agrícola E Ambient 2011;15:316-21.

[44] HERAKOVICH CT. Mechanics of Fibrous Composites. 1997.

[45] BENTUR A, MINDESS S. Fibre Reinforced Cementitious Composites. Segunda Edição. 1990.

[46] KAW AK. Mechanics of Composite Materials. Segunda Edição. 2006.

[47] LI VC, MISHRA DK, WU H-C. Matrix design for pseudo-strainhardening fibre reinforced cementitious composites. Materials Design 1995;28:586-95.

[48] RILEM. State of Art Report - Textile Reinforced Concrete, 2006.

[49] JR HS, WARDEN PG, COUTTS RSP. Ground iron blast furnace slag as a matrix for cellulose-cement materials. Cement and Concrete Composites 2001;23:389-97.

[50] PATIL N V, NETRAVALI AN. Microfibrillated cellulose-reinforced nonedible starch-based thermoset biocomposites. J Appl Polym Sci 2016:1-9. doi:10.1002/app.43803.

[51] ANDRADE F DE, MOBASHER B, FILHO RDT. Fatigue behavior of sisal fiber reinforced cement composites. Material Sci Eng A 2010;527:5507-13. doi:10.1016/j.msea.2010.05.007.

[52] FILHO RDT, GHAVAMI K, ENGLAND GL, SCRIVENER K. Development of vegetable fibre - mortar composites of improved durability. Cement Concrete Composite 2003;25:185-96.

[53] FILHO J DE AM. Durabilidade química e térmica e comportamento mecânico de compósitos de alto desempenho reforçados com fibras de sisal 2012:200.

[54] HAKAMY A, SHAIKH FUA, LOW IM. Characteristics of hemp fabric reinforced nanoclay - cement nanocomposites. Cement Concrete Composites 2014;50:27-35. doi:10.1016/j.cemconcomp.2014.03.002.

[55] CLARAMUNT J, FERNÁNDEZ-CARRASCO LJ, VENTURA H, 
ARDANUY M. Natural fiber nonwoven reinforced cement composites as sustainable materials for building envelopes 2016;115:230-9. doi:10.1016/j.conbuildmat.2016.04.044.

[56] CARDOSO PHM, BASTIAN FL, THIRÉ RMSM. Curaua Fibers / Epoxy Laminates with Improved Mechanical Properties: Effects of Fiber Treatment Conditions. Macromol Symp 2014;344:63-70. doi:10.1002/masy.201300225.

[57] GOMES A, MATSUO T, GODA K, OHGI J. Development and effect of alkali treatment on tensile properties of curaua fiber green composites. Composites Part A Appl Sci Manuf 2007;38:1811-20. doi:10.1016/j.compositesa.2007.04.010.

[58] OLIVEIRA FH DE O, HELFER AL, AMICO SC. Mechanical Behavior of Unidirectional Curaua Fiber and Glass Fiber Composites. Macromol Symp 2012;319:83-92. doi:10.1002/masy.201100202.

[59] D’ALMEIDA A, FILHO RT, FILHO JM. Cement composites reinforced by short curaua fibers. Revista Matéria 2010;15:151-6.

[60] D'ALMEIDA ALFS, FILHO JM, FILHO RDT. Use of Curaua Fibers as Reinforcement in Cement Composites. Chem Eng Trans 2009;17:171722. doi:10.3303/CET0917287.

[61] FILHO RDT, SILVA F DE A, FAIRBAIRN EMR, FILHO J DE AM. Durability of compression molded sisal fiber reinforced mortar laminates. Construction and Building Materials 2009;23:2409-20. doi:10.1016/j.conbuildmat.2008.10.012.

[62] FILHO RDT, SCRIVENER K, ENGLAND GL, GHAVAMI K. Durability of alkali-sensitive sisal and coconut fibres in cement mortar composites. Cement Concrete Composites 2000;22:127-43.

[63] CANOVAS MF, SELVA NH, KAWICHE GM. New economical solutions for improvement of durability of Portland cement mortars reinforced with sisal fibres. Materials Structures 1992;25:417-22.

[64] DIAZ JPV. Comportamento mecânico de compósitos cimentícios reforçados com fibras de pupunha 2016:148.

[65] FILHO J DE AM, SILVA F DE A, FILHO RDT. Degradation kinetics and aging mechanisms on sisal fiber cement composite systems. Cement and Concrete Composites 2013; 40:30-9. doi: 10.1016/ 
j.cemconcomp.2013.04.003.

[66] MANSUR MA, AZIZF MA. A study of jute fibre reinforced cement composites. International Journal Cement Composite Light Concrete 1982;4:75-82.

[67] HWANG C, TRAN V, HONG J, HSIEH Y. Effects of short coconut fiber on the mechanical properties, plastic cracking behavior, and impact resistance of cementitious composites. Construction and Building Materials 2016;127:984-92. doi:10.1016/j.conbuildmat.2016.09.118.

[68] BILBA K, ARSENE M, OUENSANGA A. Sugar cane bagasse fibre reinforced cement composites . Part I . Influence of the botanical components of bagasse on the setting of bagasse / cement composite. Cement and Concrete Composites 2003;25:91-6.

[69] STANCATO AC, BURKE AK, BERALDO AL. Mechanism of a vegetable waste composite with polymer-modified cement ( VWCPMC ). Cement and Concrete Composites 2005; 27:599-603. doi: 10.1016/ j.cemconcomp.2004.09.011.

[70] SEDAN D, PAGNOUX C, SMITH A, CHOTARD T. Mechanical properties of hemp fibre reinforced cement : Influence of the fibre / matrix interaction. ECERS 2008; 28:183-92. doi: 10.1016/ j.jeurceramsoc.2007.05.019.

[71] TITTELbOOM K VAN, Belie N De. Self-Healing in Cementitious Materials - A Review. Materials (Basel) 2013 :2182-217. doi: 10.3390/ ma6062182.

[72] BREUGEL K VAN. Is there a market for self-healing cement-based materials? Proc. First Int. Conf. Self Heal. Mater., The Netherlands: 2007, p. $1-9$.

[73] HYDE GW, SMITH WJ. Results of Experiments Made to Determine the Permeability of Cements and Cement Mortars. Permeability Cem 1889:199-207.

[74] EDVARDSEN C. Water Permeability and Autougenous Healing of Cracks in Concrete. ACI Mater J 1999:448-54.

[75] YANG Y, LEPECH MD, YANG E, LI VC. Autogenous healing of engineered cementitious composites under wet - dry cycles. Cement and Concrete Research 2009;39:382-90. doi:10.1016/j.cemconres.2009.01.013. 
[76] LEPECH MD, LI VC. Water permeability of engineered cementitious composites. Cement and Concrete Composites 2009;31:744-53. doi:10.1016/j.cemconcomp.2009.07.002.

[77] ŞAHMARAN M, YILDIRIM G, OZBAY E, AHMED K, LACHEMI M. Self-healing ability of cementitious composites: effect of addition of pre-soaked expanded perlite. Mag Concr Res 2014;66:409-19.

[78] ALYOUSIF A, LACHEMI M, YILDIRIM G, ŞAHMARAN M. Effect of Self-Healing on the Different Transport Properties of Cementitious Composites. J Adv Concr Technol 2015; 13:112-23. doi: 10.3151/ jact.13.112.

[79] SAHMARAN M, YILDIRIM G, ERDEM TK. Self-healing capability of cementitious composites incorporating different supplementary cementitious materials. Cement and Concrete Composites 2013;35:89101. doi:10.1016/j.cemconcomp.2012.08.013.

[80] MUSTAFA Ş, LI VC. Durability properties of micro-cracked ECC containing high volumes fly ash. Cement and Concrete Composites 2009;39:1033-43. doi:10.1016/j.cemconres.2009.07.009.

[81] ZHANG Z, QIAN S, MA H. Investigating mechanical properties and self-healing behavior of micro-cracked ECC with different volume of fly ash. Construction Building Materials 2014; 52:17-23. doi: 10.1016/ j.conbuildmat.2013.11.001.

[82] YANG Y, YANG E, LI VC. Autogenous healing of engineered cementitious composites at early age. Cement Concrete Research 2011;41:176-83. doi:10.1016/j.cemconres.2010.11.002.

[83] FERRARA L, KRELANI V, GEMINIANI M, GORLEZZA R. High performance fiber reinforced cementitious composites: autogenous self healing materials n.d.:10.

[84] SNOECK D, PH D, BELIE N DE, PH D. Repeated Autogenous Healing in Strain-Hardening Cementitious Composites by Using Superabsorbent Polymers. ASCE J Mater Civ Eng 2016;28:1-11. doi:10.1061/(ASCE)MT.1943-5533.

[85] SNOECK D. Improved multiple cracking and autogenous healing in cementitious materials by means of chemically-treated natural fibres. Biosyst Eng 2015;39:87-99. doi:10.1016/j.biosystemseng.2015.08.007. 
[86] WANG JY, SNOECK D, VLIERBERGHE S VAN, VERSTRAETE W, BELIE N DE. Application of hydrogel encapsulated carbonate precipitating bacteria for approaching a realistic self-healing in concrete. Construction and Building Materials 2014;68:110-9. doi:10.1016/j.conbuildmat.2014.06.018.

[87] SNOECK D, BELIE N DE. From straw in bricks to modern use of microfibers in cementitious composites for improved autogenous healing - A review. Construction Building Materials 2015;95:774-87. doi:10.1016/j.conbuildmat.2015.07.018.

[88] NeVille A. Autogenous Healing - A Concrete Miracle ? Concr Int 2002:76-82.

[89] WU M, JOHANNESSON B, GEIKER M. A review : Self-healing in cementitious materials and engineered cementitious composite as a self-healing material. Construction Building Materials 2012;28:571-83. doi:10.1016/j.conbuildmat.2011.08.086.

[90] HUA XI. Self-healing of Engineered Cementitious Composites (ECC) in Concrete Repair System. 2010.

[91] YILDIRIM G, KESKIN ÖK, KESKIN SB, SAHMARAN M, LACHEMI M. A review of intrinsic self-healing capability of engineered cementitious composites: Recovery of transport and mechanical properties. Construction and Building Materials 2015;101:10-21. doi:10.1016/j.conbuildmat.2015.10.018.

[92] SNOECK D, DEWANCKELE J, CNUDDE V, BELIE N DE. X-ray computed microtomography to study autogenous healing of cementitious materials promoted by superabsorbent polymers. Cement and Concrete Composites 2016; 65:83-93. doi: 10.1016/ j.cemconcomp.2015.10.016.

[93] LEE HXD, WONG HS, BUENFELD NR. Self-sealing of cracks in concrete using superabsorbent polymers. Cement and Concrete Research 2016;79:194-208. doi:10.1016/j.cemconres.2015.09.008.

[94] MIGNON A, SNOECK D, SCHAUBROECK D, LUICKX N, DUBRUEL P, VLIERBERGHE $S$ VAN, et al. pH-responsive superabsorbent polymers : A pathway to self-healing of mortar. React Funct Polym 2015;93:68-76. doi:10.1016/j.reactfunctpolym.2015.06.003. 
[95] MIGNON A, SNOECK D, HALLUIN KD, BALCAEN L, VANHAECKE F, DUBRUEL P, et al. Alginate biopolymers : Counteracting the impact of superabsorbent polymers on mortar strength. Construction and Building Materials 2016; 110:169-74. doi: 10.1016/ j.conbuildmat.2016.02.033.

[96] SNOECK D, BELIE N DE. Mechanical and self-healing properties of cementitious composites reinforced with flax and cottonised flax, and compared with polyvinyl alcohol fibres. Biosyst Eng 2012;111:325-35. doi:10.1016/j.biosystemseng.2011.12.005.

[97] TITTELBOOM K VAN, WANG J, ARAÚJO M, SNOECK D, GRUYAERT E, DEBBAUT B, et al. Comparison of different approaches for self-healing concrete in a large-scale lab test. Construction Building Materials 2016; 107:125-37. doi: 10.1016/ j.conbuildmat.2015.12.186.

[98] ŞAHMARAN M, KESKIN SB, OZERKAN G, YAMAN IO. Self-healing of mechanically-loaded self consolidating concretes with high volumes of fly ash. Cement Concrete Composits 2008; 30:872-9. doi: 10.1016/j.cemconcomp.2008.07.001.

[99] SiSOMPHON K, COPUROGLU O, KOENDERS EAB. Composites Selfhealing of surface cracks in mortars with expansive additive and crystalline additive. Cement and Concrete Composites 2012;34:566-74. doi:10.1016/j.cemconcomp.2012.01.005.

[100] SCHLANGEN E, JONKERS H, QIAN S, GARCIA A. Recent advances on self healing of concrete. FRSMCOS7, 2010, p. 8.

[101] JONKERS HM, THIJSSEN A, MUYZER G, COPUROGLU O, SCHLANGEN E. Application of bacteria as self-healing agent for the development of sustainable concrete. Ecol Eng 2010;36:230-5. doi:10.1016/j.ecoleng.2008.12.036.

[102] JONKERS HM. Self-healing concrete. Ingenia 2011:39-41.

[103] WIKTOR V, JONKERS HM. Quantification of crack-healing in novel bacteria-based self-healing concrete. Cement and Concrete Composites 2011;33:763-70. doi:10.1016/j.cemconcomp.2011.03.012.

[104] JONKERS HM. Bacteria-based self-healing concrete. Heron 2011;56:112. 
[105] BEACH G. New concrete can repair its own cracks with bacteria 2015:http://inhabitat.com/new-concrete-can-repair-its-o.

http://inhabitat.com/new-concrete-can-repair-its-own-cracks-with-bacteria/ (Último acesso em 15 de março de 2017).

[106] SONG G, MA N, LI H-N. Applications of shape memory alloys in civil structures. Engineering Structures 2006; 28:1266-74. doi: 10.1016/ j.engstruct.2005.12.010.

[107] LI X, LI M, SONG G. Energy-dissipating and self-repairing SMA- ECC composite material system. Smart Materials Structures 2015;24:1-15. doi:10.1088/0964-1726/24/2/025024.

[108] JEFFERSON A, JOSEPH C, LARK R, ISAACS B, DUNN S, WEAGER B. A new system for crack closure of cementitious materials using shrinkable polymers. Cement and Concrete Research 2010;40:795-801. doi:10.1016/j.cemconres.2010.01.004.

[109] KAN L, SHI H. Investigation of self-healing behavior of Engineered Cementitious Composites ( ECC ) materials. Construction and Building Materials 2012;29:348-56. doi:10.1016/j.conbuildmat.2011.10.051.

[110] QIAN S, ZHOU J, ROOIJ MR DE, SCHLANGEN E, YE G, BREUGEL K VAN. Self-healing behavior of strain hardening cementitious composites incorporating local waste materials. Cement and Concrete Composites 2009;31:613-21. doi:10.1016/j.cemconcomp.2009.03.003.

[111] SUTTON MA, WALTERS WJ, PETERS WH, RANSON WF, MCNEIL SR. Determination of displacements using an improved digital correlation method. Image Vis Comput 1983;1:133-9.

[112] SUTTON MA, TURNER JL, BRUCK HA, CHAE TA. Full . field Representation of Discretely Sampled Surface Deformation for Displacement and Strain Analysis. Exp Mech 1991:168-77.

[113] YAO Y, SILVA FA, BUTLER M, MECHTCHERINE V, MOBASHER B. Tension stiffening in textile-reinforced concrete under high speed tensile loads. Cement and Concrete Composites 2015;64:49-61. doi:10.1016/j.cemconcomp.2015.07.009.

[114] DIMAS ASR, YAO Y, SILVA F DE A, FILHO RDT, MOBASHER B. Experimental investigation and modelling of the temperature effects on the tensile behavior of textile reinforced refractory concretes. Cement 
and Concrete Composites 2017; 75:51-61. doi: 10.1016/ j.cemconcomp.2016.11.003.

[115] TRINDADE ACC, ARÊAS IOM, ALMEIDA DCT, ALCAMAND2 HA, BORGES PHR, SILVA FA, et al. Mechanical behavior of geopolymeric composites reinforced with natural fibers. 4th Int. Conf. Remind. StrainHardening Cem. Compos., 2017.

[116] BOSHOFF WP, MECHTCHERINE V, ZIJL GPAG Van. Cement and Concrete Research Characterising the time-dependant behaviour on the single fi bre level of SHCC : Part 1 : Mechanism of fibre pull-out creep. Cement and Concrete Research 2009; 39:779-86. doi: 10.1016/j.cemconres.2009.06.007.

[117] BARROS JAO, SILVA F DE A, FILHO RDT. Experimental and numerical research on the potentialities of layered reinforcement configuration of continuous sisal fibers for thin mortar panels. Construction and Building Materials 2016; 102:792-801. doi: 10.1016/j.conbuildmat.2015.11.018.

[118] SILVA RMC. Propriedades Mecânicas de Concretos Têxteis Sob Carregamentos Estáticos e Dinâmicos. 2017 Dissertação de mestrado não publicada 


\section{Anexo A}

Outras imagens das lâminas delgadas são encontradas nessa seção.

(a)

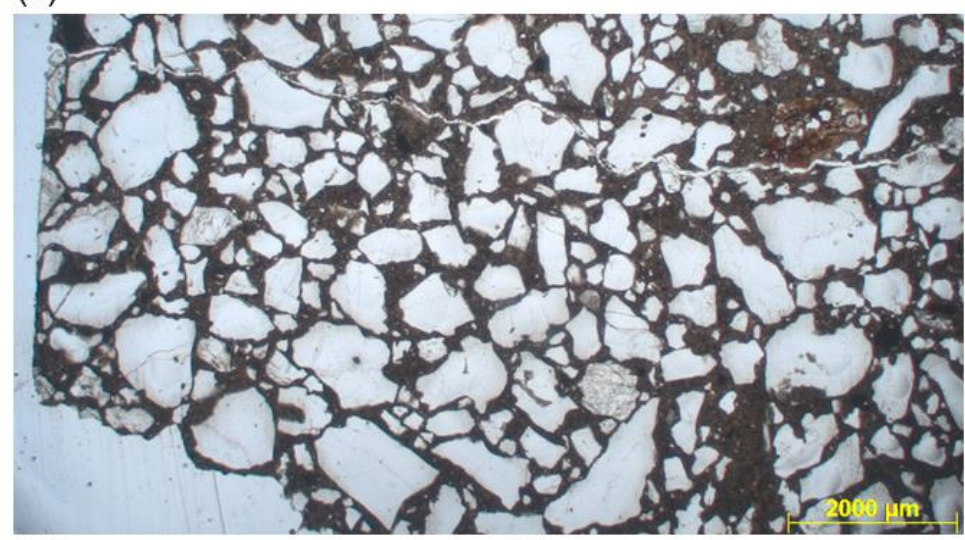

(b)

(c)
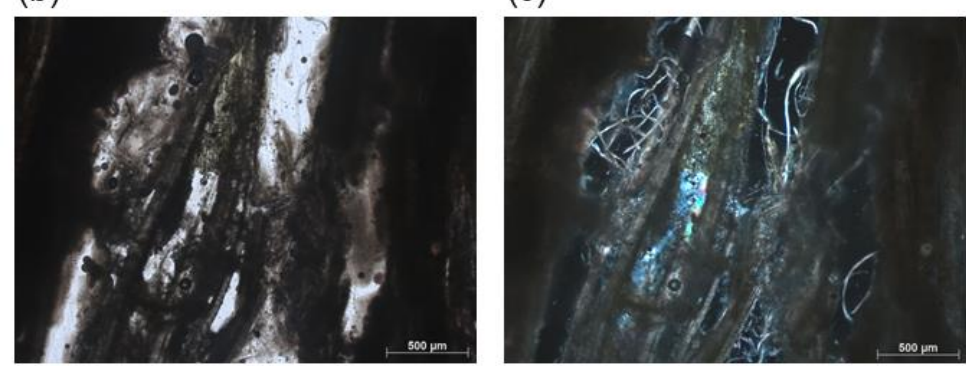

Figura 1 - Micrografia da lâmina delgada S1. (a) Propagação da fissura por entre a zona interfacial dos agregados; fibra transversal sob (b) luz polarizada normal e; (c) luz polarizada cruzada. 
(a)

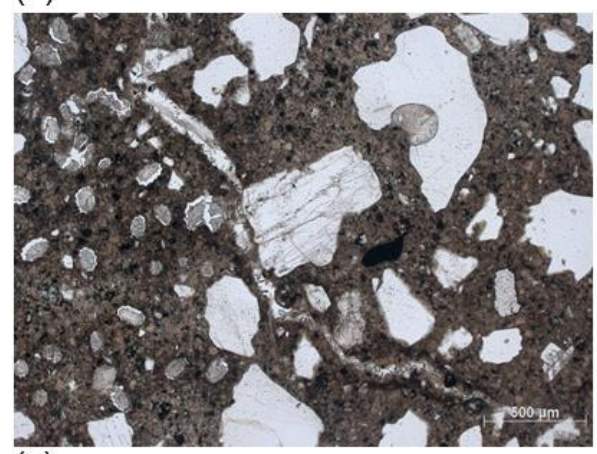

(c)

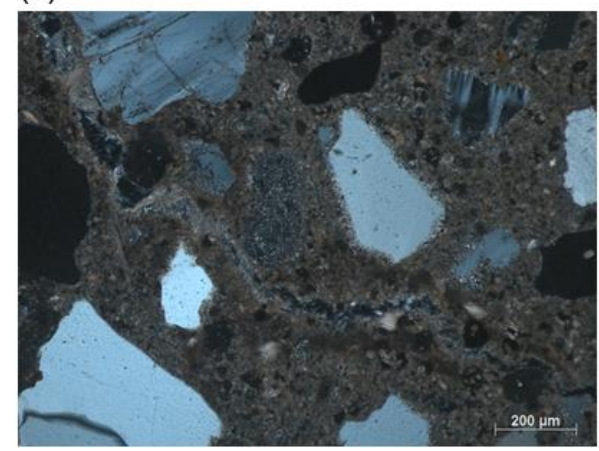

(b)

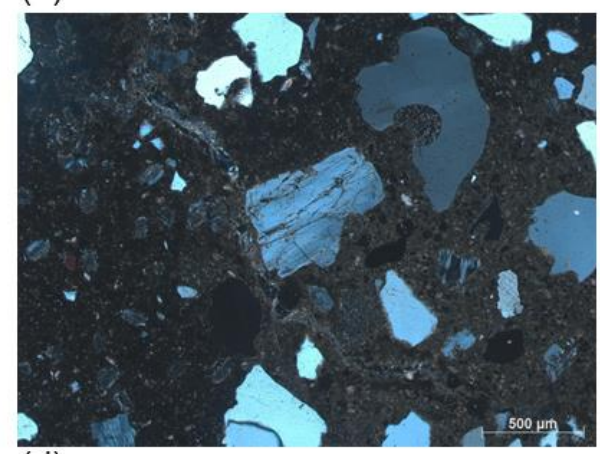

(d)

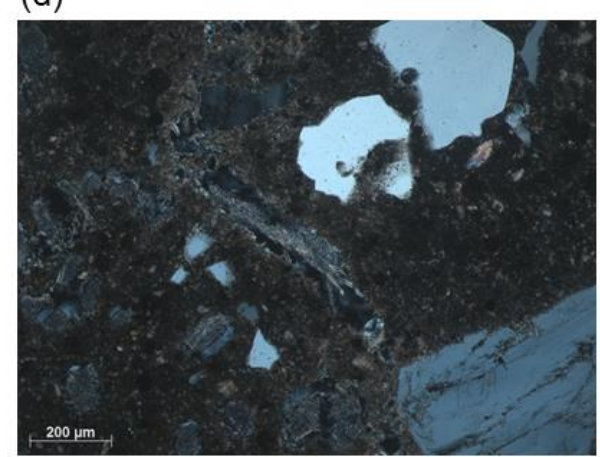

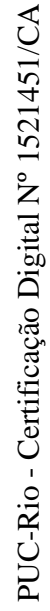

Figura 2 - Fissura mostrada no Capítulo 5 sob luz polarizada cruzada (b), (c) e (d).

(a)

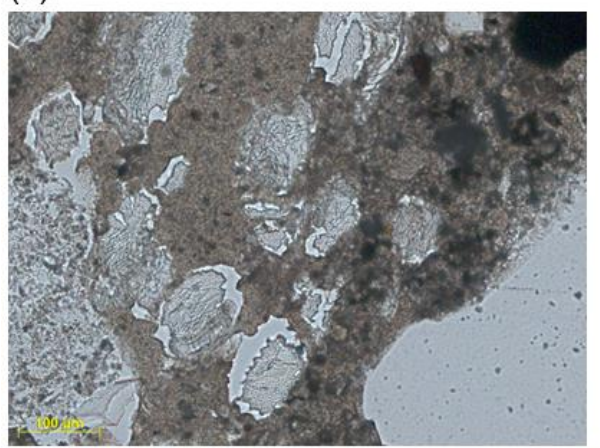

(c)

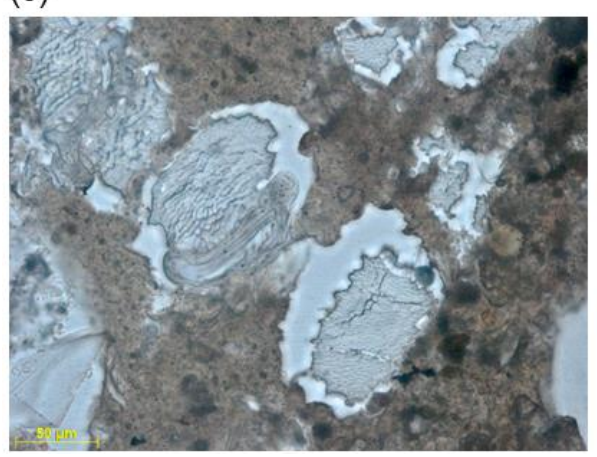

(b)

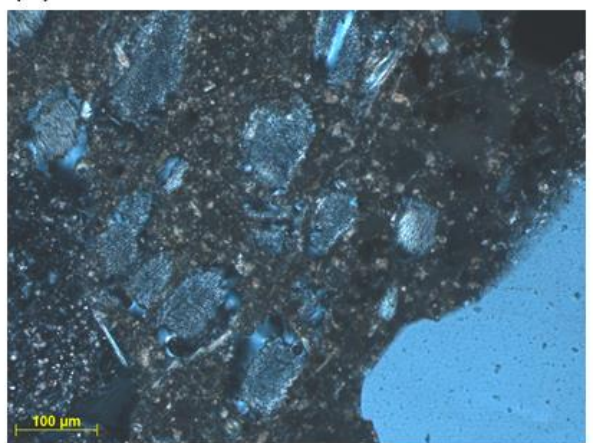

(d)

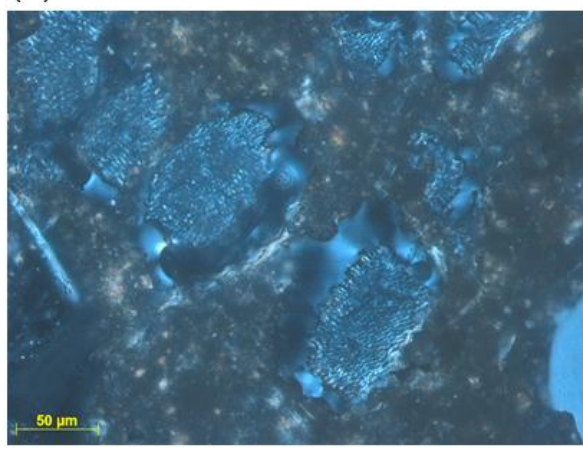

Figura 3 - Micrografias ressaltando a microestrutura transversal da fibra de curauá. 